NIST

PUBLICATIONS

\title{
Intercomparison Study of Rockwell Hardness Test Blocks
}

\section{T. Robert Shives}

Mechanical Propertles and Performance

and

John H. Smith

Metallurgy Divislon

U.S. DEPARTMENT OF COMMERCE National Institute of Standards and Technology

Galthersburg, MD 20899

U.S. DEPARTMENT OF COMMERCE

Robert A. Mosbacher, Secretary NATONAL INSTIUTE OF STANDARDS AND TECHNOLOGY

John W. Lyons, Director

QC

100

.056

\#4531

1991

C. 2 



\section{Intercomparison Study of Rockwell Hardness Test Blocks}

\section{T. Robert Shives}

Mechanlcal Propertles and Performance

and

\section{John H. Smith}

Metallurgy DIvIsIon

U.S. DEPARTMENT OF COMMERCE Natlonal Instltute of Standards and Technology

Galthersburg, MD 20899

Fobruary 1991

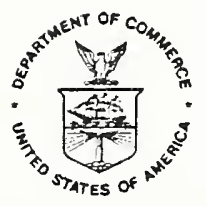





\section{INTERCOMPARISON OF ROCKWELL HARDNESS TEST BLOCKS}

\section{Abstract}

The National Institute of Standards and Technology undertook an intercomparison study of Rockwell hardness test blocks marketed in the United States. This study was done in collaboration with ASTM Subcommittee E28.06 on Hardness. Test blocks from six different manufacturers were included in the study. Measurements were made generally on seven sets of test blocks at three hardness levels for each of the HRC, HRB, HR3ON and HR30T hardness scales. Except for a small number of HRC measurements, testing was done using commercial hardness testing machines consigned to NIST for the study.

Even for the nearly ideal conditions of the study, it was found that there are significant differences among hardness test blocks of different manufacturers for some hardness levels. This is especially true for the high hardness part of the HRC scale, the lower and middle parts of the HRB scale, and parts of both the HR3ON and HR3OT scales. In these regions, the ranges of test results for blocks of different manufacturers that have similar assigned values exceed the tolerance limits for standardized test blocks according to ASTM Standard E. $18-89 a$.

The measurement results do not satisfy the ASTM E 18-89a uniformity requirements in a number of cases. This contrasts with manufacturers' results which do satisfy the ASTM requirements.

Reevaluation of $\mathrm{HRB}$ and HR30T test blocks four to five years after initial evaluation indicated that many of these are unstable. There were significant changes in hardness in a number of the blocks.

\section{Introduction}

Due to perceived differences in measured values among Rockwell hardness test blocks that have been assigned similar values by different manufacturers, the American Society for Testing and Materials (ASTM), through Subcommittee E28.06 on Hardness, established a task group to intercompare Rockwell hardness test blocks marketed in the United States. This task group, designated E28.06.07, requested that the National Institute of Standards and Technology (NIST) perform an intercomparison study of Rockwell hardness test blocks for selected scales. Blocks from four Rockwell scales, namely C, B, 30N, and 30T, were to be studied at three hardness levels each. The three nominal hardness levels for each scale were selected by the task group and are as follows:

$$
\begin{aligned}
& \text { HRC: } 25,45,63 \\
& \text { HRB: } 30,60,93 \\
& \text { HR3ON: } 46,64,80 \\
& \text { HR30T: } 36,56,78
\end{aligned}
$$

Participation in the intercomparison study was open to all companies that produce and/or market Rockwell test blocks in the United States. Since possible performance variations among Brale (diamond) indenters which are used for the Rockwell 
$\mathrm{C}$ and $\mathrm{N}$ hardness tests may significantly affect measured hardness values, a study of diamond indenters and indenter specifications was also to be undertaken. Therefore, United States manufacturers and marketers of diamond indenters were also invited to participate in the study. Although it is recognized that the $0.159-\mathrm{cm}-(1 / 16$ inch) diameter ball indenter plays a significant role in Rockwell $B$ and $30 T$ tests, these effects were not addressed at this time.

Seven companies representing six different manufacturers provided test blocks for the intercomparison study. A total of 82 test blocks was submitted to NIST. Thirty-five diamond indenters including $3 \mathrm{~A}$ scale, $20 \mathrm{C}$ scale, $11 \mathrm{~N}$ scale, and one designated both $\mathrm{C}$ and $\mathrm{N}$ scale were also submitted. Eight different companies submitted the indenters.

Two hardness testers were consigned to NIST through ASTM task group E28.06.07 for use in the intercomparison studies. A 500-series regular Rockwell tester with digital readout, model number 523R, serial number 80802506 , was consigned by the Page-Wilson Corporation to be used for the intercomparison studies of the Rockwell C and B scale test blocks. A superficial Rockwell tester with digital readout, model number DSM8, serial number 84D267, was consigned by Clark Instrument, Inc., for the intercomparison studies of the Rockwell superficial $30 \mathrm{~N}$ and $30 \mathrm{~T}$ scale test blocks.

\section{Test Procedure}

In order to proceed with the Rockwell C and $30 \mathrm{~N}$ scale hardness test block intercomparison studies before completing a NIST indenter characterization, advantage was taken of an offer from Dr. Giulio Barbato, Head of the Hardness Research Group at the Istituto di Metrologia Georgio Colonnetti (IMGC), in Turin, Italy, to examine and characterize some, but not all, of the indenters submitted to NIST for the intercomparison study. Several indenters which appeared to be more nearly geometrically symmetrical than others based on preliminary interferometry studies were chosen to be examined by the IMGC. One of the submitted $C$ indenters, designated by NIST as 112, was selected from those examined at the IMGC for use in the intercomparison study. Based on the IMGC examination, this indenter satisfied both current (1989) ASTM $^{1}$ and ISO $^{2}$ (International Organization for Standards) geometrical requirements.

In addition, a diamond indenter certified by the British Calibration Services (BCS) to meet the British Standard geometry requirements ${ }^{3}$ was also used for some series of tests. Diamond indenter geometry requirements specified by ASTM, ISO and BCS are shown in Table 1.

All of the Rockwell $C$ intercomparison hardness tests that were made at NIST and all of the HRB tests were performed on the consigned Wilson tester, whereas all of the superficial Rockwell $30 \mathrm{~N}$ and $30 \mathrm{~T}$ scale intercomparison measurements were made using the consigned Clark superficial tester. For some series of tests, the hardness tester was fitted with a Lebow 500 pound $(226.5 \mathrm{~kg}$ ) capacity load cell which was placed between the elevating screw and the anvil. The load cell was calibrated over a load range of 15.88 to 166.03 kilograms force by the NIST Force Calibration Group. An anvil was machined such that it could be attached directly to the load cell. The load cell and anvil can be seen in figure 1 . In order to read and collect the load data, the load cell was connected to a 
Lebow load cell indicator which was in turn connected to a Nicolet digitizing oscilloscope. The oscilloscope is shown in figure 2. Load was monitored during the entire time of each test that was performed with the load cell in place. A representative load vs time curve made during an HRC hardness test is shown in figure 3 .

Several series of hardness measurements which were made with the load cell in place established that both the indicated minor and major loads remained essentially constant from test to test for measurements of the same nominal hardness level. After this determination, some series of tests were performed without the load cell in the system.

All of the hardness test blocks that were submitted were tested at NIST. In addition, three $C$ scale blocks at each of the three hardness levels were tested at the IMGC. In order to facilitate the intercomparison, all of the submitted test blocks for each scale were divided into three groups, all of the blocks within each group having similar assigned hardness values. Each group was assigned a nominal hardness number corresponding to one of the hardness values requested; namely 25, 45 and 63 for the C scale, 30,60 and 93 for the B scale, 46,64 and 80 for the $30 \mathrm{~N}$ scale, and 36, 56 and 78 for the $30 \mathrm{~T}$ scale. Each block was compared only with the other blocks in the same group.

Several series of measurements were made on each group of blocks. For each series, five measurements were made on each block. The nominal distributions of measurement locations on a given block are shown in figure 4 for round test blocks and in figure 5 for square or rectangular test blocks. These measurement location patterns are the same as those used by the IMGC. All measurements within any one series were made within a one or two day time period, all were made by the same person, and all were made under similar conditions, i.e., all measurements of each series were made using the same indenter and the same anvil and without any machine adjustment. If the load cell was in place for one measurement of a series, it was in place for all measurements of that series. There may have been a change of indenter, anvil, or machine adjustment between different series for the same group of blocks.

\section{Intercomparison Test Results}

\section{Results of Hardness Tests}

Since the manufacturers' assigned hardness values for blocks within a given nominal hardness level likely differ significantly, a direct comparison of the measured hardness values for different blocks would be meaningless. A basis for the intercomparison of test blocks within each group was needed. This was arbitrarily established as the difference between the average of the five measurements made on each block at NIST and the average value of the measurements made by the manufacturer of the block at the time a value was assigned. These results are plotted in the form of bar graphs.

In each of the bar graphs, the $\mathrm{x}$-axis is labeled for the nominal hardness of the group of blocks. for which the data are shown. Except for the comparison summary bar graphs, the $\mathrm{x}$-axis also gives numbers either from 1 to 7 or from 2 to 7 , each number representing a block made by a specific manufacturer. In all bar graphs 
and tables throughout this report, wherever these numbers appear, any given number always represents blocks of the same marketer.

All bars of the same pattern in any of the bar graphs showing intercomparison results represent the "adjusted" differences between the NIST measured average values and the manufacturer's assigned values for one series of tests for each block of the group.

Results of the intercomparison hardness tests are presented in an "adjusted" form in an attempt only to show differences among similar blocks while avoiding effects of indenter, machine, machine adjustment, anvil or operator. Each series of measurements is adjusted within itself independently from any other series of measurements. This is accomplished by arbitraxily making the average difference between the manufacturer's assigned value and the NIST determined average value for the series equal to zero. Differences between the measured value and the assigned value for each block axe then adjusted accordingly. This arbitrarily assigned zero value is in no way meant to represent a "txue" or "correct" value for any blocks. Measurement results given in tabular form are presented as obtained without adjustment.

When these differences are plotted for all measurements within any given series for all the blocks in a given nominal hardness level, the difference between the highest and the lowest values represents the range of values for all the blocks of this hardness group. The relative values of the differences for the blocks of any nominal haxdness level provide a comparison of the blocks within this group.

\section{Results of HRC Tests Performed at NIST}

Four series of measurements were made at NIST on all of the HRC test blocks. The load cell with the flat plate anvil attached was in place for all four sets of measurements. The first series of measurements identified as $112-1$ was made using indenter 112. The second series of measurements (BCS-1) was made using a British Calibration Services certified indenter. Between the second and third series of measurements, the hardness tester used for all these tests was serviced by a representative of the machine manufacturer. The third and fourth series of measurements were made with indenter 112 (series 112-2) and with the BCS indenter (series BCS-2), respectively.

Individual and average results of the NIST measurements on the test blocks with nominal hardness values of $25 \mathrm{HRC}$ are given in Table 2 . The results of the manufacturers' individual measurements obtained when the blocks were assigned a hardness value as well as the averages of these values are also given. The differences between the average NIST measured values and the average of the manufacturer's measured value for each block are shown in the second column from the right. The range of these differences for all test blocks of any given series represents a comparison of the nominally 25 HRC hardness test blocks of various manufacturers. The range of values for each set of five measurements for each test block is also given in the last column of Table 2. Similarly, results for the measurements of the 45 and 63 HRC blocks are given in Tables 3 and 4 , respectively. 
The "adjusted" difference values calculated from the data presented in Table 2 are plotted in figure 6. Test results for the nominally HRC 45 and HRC 63 test blocks are similarly shown in figures 7 and 8 , respectively. As can be seen in Table 4, the individual test results obtained by the block manufacturer during block certification were not available for block 63-5. In this case, the difference between the average NIST value and the manufacturer's stated value for the block was calculated and plotted in figure 8. A summary bar graph showing the range of differences for each series of measurements for each of the three nominal. HRC hardness levels tested is shown in figure 9. For comparison, the permissible tolerance values according to ASTM Standard E 18-89a for standardized test blocks is plotted as the last bar for each hardness level. Figure 9 represents, in summary, the results of the NIST intercomparison study of the submitted HRC test blocks. As can be seen from the figure, there is some variation in the range of differences among different series for each hardness level, but the maximum range of differences for these somewhat idealized testing conditions for both the 25 and $45 \mathrm{HRC}$ levels is well below the two point tolerance value for standardized test blocks. At the higher hardness level ( $63 \mathrm{HRC}$ ), the ranges of differences are very close to, and in three cases slightly exceed, the smaller tolerance value permitted by ASTM Standard E 18-89a.

\section{Results of HRC Tests Performed at the IMGC}

At the time the IMGC evaluated some of the diamond indenters that had been submitted for the intercomparison study, they also graciously agreed to evaluate three each of the nominally 25,45 and 63 HRC test blocks. In each case, blocks of manufacturers 1,3 and 7 were tested. Measurements were made using both an IMGC certified indenter (identified as C15) and NIST submitted indenter 112. Tests were conducted on the IMGC dead weight standardizing machine ${ }^{4}$ rather than on a commercial machine. The results of the measurements on the nominally 25 HRC, 45 HRC and 63 HRC test blocks are presented in Tables 5, 6 and 7 , respectively. The differences between the average IMGC measured value and the average value obtained from the manufacturer's measurements are shown in figures 10,11 and 12 for the nominally 25, 45 and 63 HRC test blocks. Since the results shown in these figures were obtained with a dead weight machine, they were not adjusted to make the average difference between the manufacturer's assigned value and the IMGC measured value equal to zero.

A summary bar graph showing the range of differences for each series of measurements made at both the IMGC and NIST for each of the three blocks tested at each HRC nominal hardness level is shown in figure 13. It can be seen from this figure that the ranges of differences for the IMGC measurements are very similar to those for the NIST measurements.

\section{Results of HRB Tests}

Approximately 4 to 5 years had elapsed between the time the HRB test blocks were first received and the time when measurements were first made on them. Because of the time that had passed and due to the tendency for brass blocks to age and thereby change in hardness, those who had submitted blocks were given an opportunity to reevaluate the blocks that had been submitted. All suppliers except for number 7 did reevaluate their blocks and assign new values if appropriate. 
All measurements made at NIST on the HRB blocks were made within two months of the reevaluation.

Four series of measurements were made at NIST on each of the B scale test blocks that were submitted. The hardness tester was not serviced during the time span in which all of the HRB measurements were made. The load cell was in place for two of the series, $\mathrm{Al}$ and $\mathrm{Cl}$. Series $\mathrm{C} 2$ measurements were made without the load cell and with a flat anvil in place. Series C3 measurements were made without the load cell and with a spot anvil in place. All series Al measurements were made with the same $0.159-\mathrm{cm}(1 / 16-$ inch) diameter steel ball indenter. All series $\mathrm{Cl}, \mathrm{C} 2$ and $\mathrm{C} 3$ measurements were made with the same ball indenter, but one different from that used for series Al measurements.

Individual and average NIST measurements for nominally 30 HRB test blocks are given in Table 8 . Similarly, the results of the measurements on the nominally 60 and $93 \mathrm{HRB}$ test blocks are presented in Tables 9 and 10, respectively. The manufacturer's measurement values shown in Tables 8 through 10 are those obtained when the blocks were reevaluated. These data, after being adjusted in the same manner as the NIST HRC results, are presented graphically in figures 14 through 16.

A summary plot showing the range of differences for each series of measurements for each of the three nominal HRB hardness levels tested is shown in figure 17. The range of differences for the various series of tests run on the nominally $30 \mathrm{HRB}$ blocks varies from about 3.6 to $6 \mathrm{HRB}$ points, whereas the permissible tolerance values for standardized test blocks according to ASTM Standard E 18-89a is three Rockwell points. For the nominally $60 \mathrm{HRB}$ blocks, the ranges of differences for all four series are again greater than the ASTM tolerance limit for standardized blocks, and three are greater by about 50\% (about 1 HRB point). For the higher hardness blocks, nominally $90 \mathrm{HRB}$, the ranges of differences for all four series are well within the two point spread permitted for standardized blocks.

\section{Results of HR3ON Tests}

Three series of measurements were made on all of the submitted Rockwell $30 \mathrm{~N}$ blocks. The load cell was in place for the first and second series of measurements, but not for the third. The first series, designated BCS, was made using the same British Calibration Services indenter that had been used for the measurements of the $\mathrm{C}$ scale blocks. The second and third series of measurements, designated 112-1 and 112-2, respectively, were made with submitted indenter 112 . This same indenter was used for certain series of the HRC block measurements. A flat anvil was used for the measurements of the third series.

The results of the measurements on the submitted HR3ON test blocks are given in Tables 11 through 13. For graphical presentation, the results of the measurements on the HR3ON test blocks have been adjusted by arbitrarily making the average difference between the manufacturer's assigned value and the NIST determined average value equal to zero. This is the same adjustment made to the HRC and HRB data discussed above. 
The adjusted results of the measurements on the nominally 46 HR3ON test blocks are shown in figure 18. Similarly, the adjusted results for the nominally 64 HR3ON test blocks and for the nominally 80 HR3ON test blocks are given in figures 19 and 20, respectively. An intercomparison summary for the HR3ON test blocks is shown in figure 21. Again, the permissible tolerance values for standardized test blocks according to ASTM Standard E 18-89a is shown for comparison. At the nominally $46 \mathrm{HR} 30 \mathrm{~N}$ hardness level, the range of difference values for the series of tests made with the BCS indenter lies within the ASTM permitted tolerance limits for standardized test blocks. Both series of tests made at this hardness level with indenter 112 exhibit ranges of differences greater than the tolerance limit for standardized test blocks. At the nominally 64 HR3ON level, the ranges of difference values for all three series of measurements fall within the tolerance limit. At the nominally $80 \mathrm{HR} 30 \mathrm{~N}$ level, the range of difference values for the series of tests conducted with the BCS certified indenter exceeds the ASTM tolerance limit for standardized test blocks by a significant amount, whereas the ranges of difference values for the two series of tests performed with indenter 112 fall well within the tolerance limits.

\section{Results of HR30T Tests}

Three series of measurements were made on the submitted HR30T test blocks. The same ball indenter was used for all three series. The load cell was in place for series C1 measurements, but was not used for series C2 and C3. A flat anvil was used to support the test blocks for the series C2 measurements and a spot anvil was used for the $C 3$ series measurements. The individual measurement results for the HR30T test blocks are given in Tables 14,15 and 16 for the nominally 36, 56, and $78 \mathrm{HR} 30 \mathrm{~T}$ hardness levels, respectively. The differences between the values shown in the tables and the manufacturer's assigned value for each block, arbitrarily adjusted to zero based on the average for each series, are plotted in figure 22 for the nominally 36 HR3OT hardness level test blocks. The results for the 56 and 78 HR30T test blocks are plotted in a similar fashion in figures 23 and 24.

A summary plot showing the range of differences for each series of measurements at each of the nominal hardness levels is given in figure 25. As before, the tolerance limits for standardized blocks as set forth in ASTM Standard

E 18-89a are shown for comparison. The range of differences between the manufacturer's assigned value and the NIST average measured value slightly exceeds the ASTM tolerance limits for standardizing blocks for the C2 series tests at both the nominally 36 and 56 HR3OT hardness levels. Otherwise, all the difference value ranges fall within these tolerance limits.

\section{HRC Test Block Uniformity}

The range of hardness values obtained from the five measurements on any given block using the same indenter and testing conditions is an indication of the degree of uniformity of the block. The magnitudes of these ranges for each of the nominally $25 \mathrm{HRC}$ test blocks for each set of conditions for which data were taken at NIST are given in Table 2 and are plotted in figure 26. The ranges of measured values obtained by the block manufacturer when determining what hardness numbers to assign to blocks are also given. Similar plots for the nominally 45 HRC test blocks and the nominally 63 HRC test blocks are presented in figures 
27 and 28 , respectively. It should be noted that the scales of the vertical axes of figures 26 to 28 are not the same. The data on which the plots of figures 27 and 28 are based are given in Tables 3 and 4, respectively.

For comparison, the acceptable uniformity ranges for Rockwell C scale standardized test blocks according to ASTM Standard E 18-89a are plotted in each of figures 26, 27 and 28. The tolerance limit for uniformity for these blocks is $0.5 \mathrm{HRC}$ unit at hardness values of $60 \mathrm{HRC}$ and greater and $1.0 \mathrm{HRC}$ unit for hardness values less than $60 \mathrm{HRC}$.

The ranges of measurements obtained by the manufacturer when assigning values to blocks satisfy these uniformity requirements without exception. (The manufacturer's individual measurement values are not available for the test block submitted by manufacturer number 5 at the nominally 63 HRC level.) In most cases, these ranges are well below the specified limits. However, the blocks of manufacturer 2 at both the nominally 25 and $63 \mathrm{HRC}$ levels exhibit a degree of nonuniformity in the manufacturer's values as great as that permitted by the standard. The ranges of values obtained at NIST for these same two blocks with both indenter 112 and the BCS certified indenter fall well outside the acceptable standardizing test block uniformity limits. Specifically, the hardness value ranges obtained for the nominally 25 HRC block of manufacturer 2 are 3.6 and 3.4 HRC units for the two series of measurements made with indenter 112 , and 2.9 and 2.8 HRC units for the two series of measurements made with the BCS certified indenter. For the nominally 63 HRC block of manufacturer 2, the hardness value ranges are 1.3 and 1.2 for the two series of measurements with indenter 112 , and 0.8 and 1.0 HRC units for the two series of measurements made with the BCS certified indenter.

The range of hardness values obtained with indenter 112 for one other Rockwell C scale block, the nominally 25 HRC block of manufacturer 4, is greater than permitted by 0.1 and $0.4 \mathrm{HRC}$ units, respectively, for measurement series 1 and 2 .

It is interesting to compare ranges of values for series 1 measurements made with indenter 112 with series 1 measurements made with the BCS certified indenter and, similarly, series 2 measurements made with indenter 112 with series 2 measurements made with the BCS certified indenter. For 30 of the total of 42 comparisons, the ranges of values obtained with indenter 112 are greater than those obtained with the BCS indenter. In nine instances, the value ranges are the same for both indenters. For the remaining three comparisons, the hardness value ranges obtained with the BCS indenter are greater than those obtained with indenter 112. For most of the HRC blocks tested, the ranges of values obtained for the NIST measurements for both indenter 112 and the BCS indenter are greater than those obtained by the manufacturer.

\section{HRB Test Block Uniformity}

The ranges of hardness values measured at NIST for the Rockwell B scale test blocks are shown in figures 29, 30, and 31 for nominally 30,60 and 93 HRB hardness levels, respectively. Again, the ranges of values obtained by the manufacturer for these blocks are shown for comparison. The individual measurement values and range values are also given in Tables 8 through 10 . Note 
that there is a significant difference between the y-axis scale in figure 29 and the $y$-axis scales in figures 30 and 31. As for the HRC and HR30N test blocks discussed previously, the ranges of values obtained by the manufacturers satisfied the tolerance limits for standardized blocks as set forth in ASTM Standard E 18-89a for all HRB test blocks submitted for this program.

For three of the five nominally $30 \mathrm{HRB}$ blocks, the uniformity as measured at NIST is essentially within the tolerance limits for all series of measurements. For two of the blocks, the ranges for one and two series of measurements, respectively, are about 1/2 HRB point greater than allowed for standardized blocks. The ranges of measured values for block number 4, however, are 12.2 and $11.7 \mathrm{HRB}$ units for two series of measurements, and 3.4 and 4.6 units for the other two series of measurements. The individual measurement results as given in Table 8 show that the value of measurement number 1 of each series is significantly higher than the rest of the measurements. Since all the number 1 measurements were taken in the same region of the block, it would appear that this region of the block is significantly harder than the rest of the block.

For five of the seven nominally 60 HRB blocks tested, the range of values for at least one series of measurements exceeds that permitted for standardized blocks. On the other hand, for all seven blocks, the range of values for at least one series of measurements is equal to or less than the tolerance limit for standardized test blocks.

At the nominally $93 \mathrm{HRB}$ hardness level, the ranges for all four sets of measurements satisfies the requirements of the standardized block tolerance limits of ASTM E 18-89a. For two of the blocks, the ranges of values for two series of measurements exceeded the tolerance values. For block number 2, the range of values for all four series of measurements exceeds the tolerance limit for standardized blocks.

\section{HR30N Block Uniformity}

The ranges of measurements made at NIST for each of the nominally 46 HR $30 \mathrm{~N}$ test blocks are given in Table 11. These data are plotted in figure 32. The ranges of values obtained by the block manufacturers are also shown. Similarly, the ranges of measurements for the nominally 64 and 80 HR3ON test blocks are shown in figures 33 and 34, respectively. These data are also given in Tables 12 and 13, respectively. In each of figures 32 through 34, the uniformity tolerance for standardized blocks, according to ASTM Standard E 18-89a, is shown for comparison. In all cases, the manufacturer's measurement values are well within the ASTM tolerance for standardized test blocks.

The variation in the results of measurements made at NIST far exceeds the variation found by the manufacturers for most of the test blocks. In many instances, there are significant differences among the ranges for different series of measurements on the same block. Unlike the results for the HRC test blocks, there appears to be no significant effect deriving from any particular set of conditions. For six of the seven nominally $46 \mathrm{HR} 30 \mathrm{~N}$ blocks, the range of values for at least one series of measurements exceeds the uniformity tolerance for standardized blocks. On the other hand, for five of these same seven blocks, 
at least one series of measurements satisfies the uniformity tolerance for standardized test blocks.

Similar results are found for the nominally $64 \mathrm{HR} 30 \mathrm{~N}$ blocks. For the nominally 80 HR3ON blocks, all series of measurements satisfy the uniformity tolerance for four of the seven blocks tested, and at least one series of measurements satisfies the uniformity requirement for all seven blocks. The same measurement sequence was observed for all series of measurements; that is, the first measurement of all series of measurements was taken in the same general area of a block (designated 1 in figures 4 and 5), the second measurement of each series of measurements was taken in the same general area of a block (designated 2 in figures 4 and 5), but in an area different from that where the first measurements were taken. Therefore, it is difficult to explain the sometimes rather large difference in values obtained in the same areas of blocks as well as the varying ranges for various series of measurements. In any case, the results of the NIST measurements indicate that many of the submitted HR30N blocks do not satisfy the ASTM uniformity tolerance for standardized blocks.

\section{HR30T Test Block Uniformity}

The ranges of test measurement values for each set of measurements on the submitted HR30T test blocks are shown in figures 35,36 , and 37 for nominally 36,56 , and 78 HR30T test blocks, respectively. As before, the ranges of values obtained by the manufacturer is given where available, and the tolerance limit for standardized test blocks as called for in ASTM E 18-89a is also shown for comparison. The individual measurement results for the blocks of manufacturer number 4 are not available. This information is also given in tabular form in Tables 14, 15, and 16 .

Consistent with the data for the test blocks of the other scales discussed, in all cases where the manufacturer's individual measurement values are available, the ranges of these values are well below the tolerance limit for standardized test blocks.

Of the six blocks at the nominally 36 HR30T hardness level that were tested, the ranges of all series of measurements are within the tolerance limit of standardized test blocks only for the block of manufacturer number 5 . In two cases, the ranges of values for all three series of measurements exceed the tolerance limit. The ranges of values for the block of manufacturer number 5 are 3.9 and 7.7 HR30T units for two series of measurements, whereas the range for the third set is significantly lower and well within the tolerance limit for standardized test blocks.

For six of the seven nominally 56 HR30T blocks, the ranges for at least two of the three sets of measurements are greater than the permitted tolerance for standardized blocks. For only three of the blocks do the ranges of measurements for any series of measurements satisfy the tolerance requirements for standardized blocks, and only for the block of manufacturer number 7 do all three series of measurements fall within the tolerance limit.

At the 78 HR30T hardness level, the ranges of values for at least one series of measurements for each test block satisfies the uniformity requirements for 
standardized test blocks. On the other hand, the ranges of values for two series of measurements for four of the seven blocks fail to meet this requirement. For three of the test blocks at this level, the ranges for all three series of measurements fall within the tolerance limit for standardized test blocks.

\section{Test Block Stability}

Whereas test block stability over time was not originally intended to be part of this study, there are data regarding changes in hardness values with time for the HRB and the HR30T test blocks that should be mentioned. Differences between the manufacturer's original assigned value and the manufacturer's assigned value after reevaluation are plotted in figures 38 through 40 for nominally 30,60 , and $93 \mathrm{HRB}$ test blocks, respectively. As noted earlier, manufacturer 7 chose not to reevaluate its blocks. Over the four to five year period between evaluations, there were significant changes in the values assigned to some blocks. For the most part, hardness values decreased over time. The assigned hardness value of the nominally $30 \mathrm{HRB}$ block from manufacturer number 2 decreased by 3 HRB units. Four other blocks decreased in hardness by 1.5 to 1.9 HRB units. Only the blocks of manufacturer number 4 exhibited essentially no change at any of the three hardness levels.

Differences between the original assigned values for the HR3OT test blocks and the assigned values after reevaluation are shown in figures 41 through 43 for the nominally 36, 56, and 78 HR30T hardness levels. As for the HRB test blocks, there were significant changes in the assigned values for some blocks over the four to five year time period. All significant changes in hardness were decreases.

\section{Discussion}

The principal results of this intercomparison study can be found in the comparison summary plots of NIST measurements for each of the four Rockwell hardness scales considered. These plots are given in figures 9, 17, 21 and 25. It should be remembered that the measurements for this study were made under nearly ideal conditions. Although the measurements were made on commercial testing machines, all measurements of any given series were made on the same testing machine in a time period spanning no more than two days and were made by one person. All other conditions such as indenter, use or non-use of a load cell, and anvil were kept constant throughout a series of measurements.

The Rockwell C scale test blocks submitted for the intercomparison study indicate differences among blocks of various manufacturers. For the nominally 25 HRC test blocks, the NIST results indicate a difference of approximately one full HRC unit between the values for the two blocks reading the highest and the lowest compared to the manufacturers' assigned values. This difference for the nominally HRC 45 test blocks is from about 1.0 to 1.2 HRC units. For the higher hardness, nominally 63 HRC test blocks, this difference is about 1.2 HRC units. The difference for the nominally $63 \mathrm{HRC}$ blocks is greater than the allowed tolerances specified in ASTM Standard E 18-89a.

For the HRB blocks, the differences among blocks is greatest at the lower end and in the middle of the hardness scale. The difference between the blocks 
reading the highest and lowest compared to the manufacturers' assigned values varies from about 3.6 to $6.0 \mathrm{HRB}$ points at the $30 \mathrm{HRB}$ level. At the $60 \mathrm{HRB}$ level, this difference ranges from about 2.4 to $3.5 \mathrm{HRB}$ points. At the upper part of the scale, the differences drop to from about 1.1 to 1.5 points.

Test results for the HR30N blocks indicate the least difference among manufacturers in the middle part of the scale. The range of differences at the lower part of the scale exceeds the ASTM tolerance for standardized test blocks in two out of three cases. The ranges of differences for these series are about 2.4 and $2.9 \mathrm{HR} 30 \mathrm{~N}$ units. At the $80 \mathrm{HR} 30 \mathrm{~N}$ level, the difference for one series of measurements is much higher than the other two. The measurements of this series were made with the BCS certified indenter. For two of the nominally 80 HR $30 \mathrm{~N}$ blocks, the NIST average measured values for this series do not agree well with the measurements of the other series.

For the HR30T blocks, the range of differences between NIST measurements and the manufacturers' measurements exceeds the ASTM tolerance for standardized blocks in only two cases, one at the $36 \mathrm{HR} 30 \mathrm{~T}$ level and one at the $56 \mathrm{HR} 30 \mathrm{~T}$ level. In the former case, the value exceeds the tolerance by about $0.25 \mathrm{HR} 30 \mathrm{~T}$ unit and in the latter case, the value exceeds the tolerance by about 0.2 unit.

For all the test blocks submitted for this study, the uniformity tolerances for Rockwell standardized test blocks according to ASTM Standard E 18-89a are satisfied by the manufacturers' data where they are available. The ranges of values for many of the series of measurements made at NIST are greater that those allowed for standardized test blocks. All series of measurements made at NIST satisfy the standardized block tolerance requirement for sixteen of the twentyone HRC blocks tested. For the HRB blocks, eight of the twenty blocks tested satisfy this requirement. Uniformity based on the NIST measurements is poorer for the superficial blocks, with only six of twenty-one HR3ON blocks and five of twenty HR30T blocks satisfying the standardized test block tolerance.

\section{Conclusions}

Based on the results of this work, for some hardness levels of the Rockwell hardness scales considered, there are significant differences among hardness test blocks of different manufacturers that have similar assigned values. The differences for the HRC blocks appear to be significant only at the high hardness end of the scale, and even then the differences are only slightly greater than the tolerance requirement for standardized test blocks as specified in ASTM Standard E 18-89a. For the HRB test blocks, the differences between blocks of different manufacturers are within the tolerance limits for standardized blocks at the high end of the scale, but these differences fall outside the tolerance limits at the two other hardness levels where blocks were tested.

For the HR30N test blocks, the differences among blocks is less than allowed for standardized blocks at the 64 HR3ON level, but the differences for some series of measurements at the high and low ends of the scale do not satisfy the standardized block tolerance. At the high end of the scale for the HR30T test blocks, differences among blocks satisfy tolerance limits. For the other two levels of the scale where tests were performed, the differences for one set of measurements in each case fails to satisfy the tolerance criteria. 
In summary, the NIST measurements indicate that the differences among blocks of different manufacturers are greater than the tolerance limits for standardized test blocks as specified in ASTM Standard E 18-89a in several instances. These same measurements also indicate that many of the blocks do not satisfy uniformity requirements for standardized test blocks. The lack of hardness test block stability for many of the HRB and HR3OT test blocks is significant and should be targeted for future consideration.

\section{Acknowledgement}

Appreciation is expressed to Richard J. Fields and Samuel R. Low, III, both of the NIST Mechanical Properties and Performance Group, for technical advice.

\section{Disclaimer}

The use of certain commercial equipment for the intercomparison study does not imply recommendation or endorsement by NIST, nor does it imply that these products are the best available for the purpose.

\section{$\underline{\text { References }}$}

1. Standard Test Methods for Rockwell Hardness and Rockwell Superficial Hardness of Metallic Materials, Designation E 18-89a, American Society for Testing and Materials, Vol. 03.01,1989.

2. Metallic materials - Hardness test - Calibration of standardized blocks to be used for Rockwell hardness testing machines (scales A - B - C - D - E $\mathrm{F}-\mathrm{G}-\mathrm{H}-\mathrm{K}$, International (ISO) Standard 674-1988-12-01, 1988.

3. British Standard Method for Rockwe11 Hardness Test, Part 1 . Testing of metals, B.S. 891: Part 1: 1962.

4. Giulio Barbato, Sergio Desogus and Raffaello Levi, Design and Performance of a Deadweight Standard Rockwel1 Hardness Testing Machine, Journal of Testing and Evaluation, Vol. 6, No. 4, American Society for Testing and Materials, 1978. 
Table 1. Basic Diamond Indenter Geometry Specifications
ASTM
E 18-89a
ISO
$674-1988$
BCS
BS $891-1989$

Cone angle

$$
\begin{array}{ll} 
& 120^{\circ} \\
+ & 0.35^{\circ}
\end{array}
$$

$120^{\circ}$

$\pm 0.10^{\circ}$

$120^{\circ}$

$\pm 0.35^{\circ}$

Tip radius

$0.200 \mathrm{~mm}$
$\pm 0.010 \mathrm{~mm}$

$0.200 \mathrm{~mm}$
$+0.005 \mathrm{~mm}$

$0.200 \mathrm{~mm}$

$\pm 0.010 \mathrm{~mm}$ 
Table 2. Results of NIST Hardness Measurements on Nomina1ly 25 HRC Test Blocks

\begin{tabular}{|c|c|c|c|c|c|c|c|c|c|c|c|}
\hline \multirow{2}{*}{ Block } & \multirow[t]{2}{*}{ Series } & \multicolumn{6}{|c|}{ Measurements } & \multirow[t]{2}{*}{ Avg } & \multirow{2}{*}{$\begin{array}{l}\text { Assigned } \\
\text { Value }\end{array}$} & \multirow{2}{*}{$\begin{array}{c}\text { Difference } \\
\text { Manufact/NIST }\end{array}$} & \multirow[t]{2}{*}{ Range } \\
\hline & & 1 & 2 & 3 & 4 & 5 & 6 & & & & \\
\hline \multirow[t]{5}{*}{$25 \cdot 1$} & $112-1$ & 24.3 & 24.6 & 24.6 & 24.3 & 24.2 & & 24.40 & 24.6 & -0.20 & 0.4 \\
\hline & $B C S-1$ & 24.1 & 24.4 & 24.1 & 24.3 & 24.2 & & 24.22 & & -0.38 & 0.3 \\
\hline & $112-2$ & 25.4 & 25.1 & 25.0 & 25.2 & 25.4 & & 25.22 & & +0.62 & 0.4 \\
\hline & BCS - 2 & 25.5 & 25.2 & 25.2 & 25.4 & 25.3 & & 25.32 & & +0.72 & 0.3 \\
\hline & MANUFACT & 24.7 & 24.6 & 24.6 & 24.6 & 24.6 & 24.5 & 24.60 & & & 0.2 \\
\hline \multirow[t]{5}{*}{$25-2$} & $112-1$ & 23.6 & 22.4 & 21.5 & 25.0 & 25.1 & & 23.52 & 25.0 & -1.48 & 3.6 \\
\hline & $B C S-1$ & 25.0 & 22.2 & 25.1 & 24.0 & 22.5 & & 23.76 & & .1 .24 & 2.9 \\
\hline & $112-2$ & 26.4 & 23.3 & 26.6 & 25.2 & 23.2 & & 24.94 & & -0.06 & 3.4 \\
\hline & $B C S-2$ & 26.0 & 23.2 & 25.5 & 25.7 & 23.3 & & 24.74 & & -0.26 & 2.8 \\
\hline & MANUFACT & 25.5 & 25.0 & 25.1 & 25.2 & 24.5 & 24.7 & 25.00 & & & 1.0 \\
\hline \multirow[t]{5}{*}{$25-3$} & $112-1$ & 22.8 & 22.5 & 22.8 & 22.9 & 22.9 & & 22.78 & 23.8 & -0.99 & 0.4 \\
\hline & $B C S-1$ & 22.9 & 22.8 & 23.2 & 22.9 & 22.8 & & 22.92 & & -0.85 & 0.4 \\
\hline & $112-2$ & 23.8 & 24.0 & 24.2 & 24.2 & 24.0 & & 24.04 & & +0.27 & 0.4 \\
\hline & $B C S \cdot 2$ & 24.0 & 24.1 & 23.9 & 24.1 & 24.1 & & 24.04 & & +0.27 & 0.2 \\
\hline & MANUFACT & 23.9 & 23.8 & 23.7 & 23.8 & 23.7 & 23.7 & 23.77 & & & 0.2 \\
\hline \multirow[t]{5}{*}{$25-4$} & $112-1$ & 24.4 & 24.9 & 23.8 & 24.1 & 24.3 & & 24.30 & 25.6 & -1.28 & 1.1 \\
\hline & $B C S-1$ & 24.1 & 24.9 & 24.6 & 24.7 & 24.1 & & 24.48 & & -1.10 & 0.8 \\
\hline & $112-2$ & 25.8 & 26.5 & 25.1 & 26.0 & 26.1 & & 25.90 & & +0.32 & 1.4 \\
\hline & - BCS - 2 & 25.5 & 26.1 & 25.2 & 25.7 & 25.9 & & 25.68 & & +0.10 & 0.9 \\
\hline & MANUFACT & 25.8 & 25.5 & 25.5 & 25.5 & 25.8 & 25.4 & 25.58 & & & 0.3 \\
\hline \multirow[t]{5}{*}{$25-5$} & $112-1$ & 25.6 & 25.9 & 25.9 & 25.9 & 26.0 & & 25.86 & 26.2 & -0.39 & 0.4 \\
\hline & $B C S-1$ & 25.6 & 25.6 & 25.8 & 25.6 & 25.4 & & 25.60 & & -0.65 & 0.4 \\
\hline & $122-2$ & 27.2 & 26.8 & 27.2 & 27.2 & 27.3 & & 27.14 & & +0.89 & 0.5 \\
\hline & BCS -2 & 26.6 & 27.0 & 26.6 & 26.5 & 26.7 & & 26.68 & & +0.43 & 0.4 \\
\hline & MANUFACT & 26.4 & 26.1 & 26.1 & 26.4 & 26.1 & 26.4 & 26.25 & & & 0.3 \\
\hline \multirow[t]{5}{*}{$25-6$} & $112-1$ & 26.0 & 26.5 & 25.8 & 25.9 & 26.1 & & 26.06 & 26.9 & -0.84 & 0.7 \\
\hline & $3 C S-1$ & 26.1 & 26.4 & 26.2 & 26.1 & 26.0 & & 26.16 & & -0.74 & 0.4 \\
\hline & $112-2$ & 27.3 & 28.0 & 27.7 & 27.8 & 27.6 & & 27.68 & & +0.78 & 0.7 \\
\hline & BCS - 2 & 27.4 & 27.2 & 27.3 & 27.7 & 27.1 & & 27.34 & & +0.44 & 0.6 \\
\hline & MANUFACT & 27.0 & 26.8 & 27.0 & 27.0 & 26.8 & 26.8 & 26.90 & & & 0.2 \\
\hline \multirow[t]{5}{*}{$25-7$} & $112-1$ & 20.7 & 20.9 & 20.6 & 20.8 & 20.6 & & 20.72 & 21.6 & -0.91 & 0.3 \\
\hline & BCS - 1 & 20.7 & 20.9 & 20.4 & 20.5 & 20.6 & & 20.62 & & -1.01 & 0.5 \\
\hline & $112-2$ & 22.3 & 22.5 & 22.2 & 22.6 & 22.3 & & 22.38 & & +0.75 & 0.4 \\
\hline & BCS - 2 & 21.7 & 22.0 & 21.9 & 21.4 & 21.5 & & 21.70 & & +0.07 & 0.6 \\
\hline & MANUFACT & 21.7 & 21.7 & 21.6 & 21.4 & 21.7 & 21.7 & 21.63 & & & 0.3 \\
\hline
\end{tabular}


Table 3. Results of NIST Hardness Measurements on Nominally 45 HRC Test Blocks

Block Series

45-1 112-1

BCS - 1

112-2

BCS - 2

MANUFACT

45-2 $112-1$

BCS - 1

112-2

BCS - 2

MANUFACT

45-3 112-1

BCS - 1

112-2

BCS - 2

MANUFACT

$45-4 \quad 112-1$

BCS - 1

112-2

BCS - 2

MANUFACT

45-5 112-1

BCS - 1

112- 2

BCS - 2

MANUFACT

$45-6 \quad 112-1$

BCS - 1

112- 2

BCS - 2

MANUFACT

$45-7 \quad 112-1$

BCS - 1

112- 2

BCS - 2

MANUFACT

$1 \quad 2 \begin{array}{lllll}\text { Measurements } \\ & 3 & 4 & 5 & 6\end{array}$

Avg Assigned Difference Range Value Manufact/NIST

$\begin{array}{llllll}44.8 & 45.0 & 44.7 & 44.8 & 44.7 & \\ 44.6 & 44.8 & 44.6 & 44.6 & 44.7 & \\ 45.5 & 46.0 & 45.9 & 45.7 & 45.7 & \\ 45.6 & 45.8 & 45.8 & 45.6 & 45.6 & \\ 44.9 & 45.0 & 45.0 & 45.0 & 45.1 & 45.0\end{array}$

$\begin{array}{lllll}44.9 & 44.8 & 45.1 & 45.3 & 45.2 \\ 45.1 & 45.3 & 45.0 & 45.0 & 45.2\end{array}$

$\begin{array}{lllll}46.0 & 46.0 & 46.1 & 46.1 & 46.1\end{array}$

$\begin{array}{llllll}46.0 & 46.0 & 46.0 & 46.0 & 46.0\end{array}$

$\begin{array}{lllll}46.0 & 46.4 & 46.0 & 46.5 & 46.4\end{array}$

$\begin{array}{llllll}43.7 & 43.5 & 43.3 & 43.5 & 43.5\end{array}$

$\begin{array}{llllll}43.4 & 43.4 & 43.6 & 43.7 & 43.5\end{array}$

$\begin{array}{lllll}44.3 & 44.3 & 44.5 & 44.6 & 44.4\end{array}$

$\begin{array}{llllll}44.6 & 44.6 & 44.6 & 44.5 & 44.5\end{array}$

$\begin{array}{llllll}44.6 & 44.4 & 44.5 & 44.4 & 44.6\end{array}$

$\begin{array}{lllll}45.6 & 45.2 & 45.4 & 45.2 & 45.5\end{array}$

$\begin{array}{lllll}46.1 & 46.1 & 46.1 & 45.7 & 45.7\end{array}$

$\begin{array}{lllll}46.6 & 46.8 & 46.7 & 47.3 & 47.2\end{array}$

$\begin{array}{llllll}46.4 & 46.7 & 46.5 & 46.9 & 46.8\end{array}$

$\begin{array}{llllll}45.9 & 45.8 & 45.8 & 46.1 & 46.0\end{array}$

$\begin{array}{lllll}42.6 & 43.6 & 44.0 & 44.2 & 44.0\end{array}$

$\begin{array}{llllll}44.7 & 44.1 & 44.4 & 44.5 & 43.7\end{array}$

$\begin{array}{lllll}45.4 & 45.5 & 45.4 & 45.6 & 45.1\end{array}$

$\begin{array}{lllll}45.4 & 45.2 & 45.4 & 45.4 & 45.7\end{array}$

$\begin{array}{lllll}45.1 & 45.1 & 44.9 & 45.0 & 44.9\end{array}$

$\begin{array}{llllll}45.6 & 45.7 & 45.6 & 45.6 & 45.8\end{array}$

$\begin{array}{llllll}46.2 & 46.0 & 46.0 & 46.1 & 46.1\end{array}$

$\begin{array}{lllll}46.8 & 46.6 & 47.2 & 47.4 & 47.3\end{array}$

$\begin{array}{lllll}46.8 & 46.5 & 46.8 & 46.9 & 46.8\end{array}$

$\begin{array}{llllll}46.8 & 46.8 & 46.7 & 46.9 & 46.8\end{array}$

$\begin{array}{lllll}39.4 & 39.4 & 39.5 & 39.2 & 39.3\end{array}$

$\begin{array}{lllll}39.2 & 39.5 & 39.4 & 39.4 & 39.2\end{array}$

$\begin{array}{lllll}40.5 & 40.8 & 40.3 & 40.5 & 40.3\end{array}$

$\begin{array}{lllll}40.1 & 40.2 & 40.1 & 40.3 & 40.0\end{array}$

$\begin{array}{lllllll}40.4 & 40.5 & 40.6 & 40.3 & 40.4 & 40.4 & 40.43\end{array}$

45.0

45.06

45.12

46.06

46.00

$46.2 \quad 46.25$

43.50

43.52

44.42

44.56

$44.4 \quad 44.48$

46.3

45.38

45.94

46.92

46.66

$46.0 \quad 45.93$

45.66

46.08

47.06

46.76

46.80

39.36

39.34

40.48

40.14

46.8

0.72

$+0.26$

$-0.04$

$-1.32$

$+0.40$

$+0.42$

$-0.55$

$+0.01$

$+0.99$

$+0.73$

0.3

0.2

0.5

0.2

0.2

0.5

0.3

0.1

0.0

0.5

0.4

0.3

0.3

0.1

0.2

0.4

0.4

0.7

0.5

0.3

1.6

1.0

0.5

0.5

0.2

0.2

0.2

0.8

0.4

0.2

40.4

$-1.07$

0.3

$-1.09$

0.3

$+0.05$

0.5

$-0.29$

0.3

0.3

$\begin{array}{rlr} & 43.68 & 45.0 \\ & 44.28 & \\ & 45.40 \\ & 45.42 \\ 45.0 \quad 45.00\end{array}$


Table 4. Results of NIST Hardness Measurements on Nominally 63 HRC Test Blocks

\begin{tabular}{|c|c|c|c|c|c|c|c|c|c|c|c|}
\hline \multirow[t]{2}{*}{ Block } & \multirow[t]{2}{*}{ Series } & \multicolumn{6}{|c|}{ Measurements } & \multirow[t]{2}{*}{ Avg } & \multirow{2}{*}{$\begin{array}{l}\text { Assigned } \\
\text { Value }\end{array}$} & \multirow{2}{*}{$\begin{array}{c}\text { Difference } \\
\text { Manufact/NIST }\end{array}$} & \multirow[t]{2}{*}{ Range } \\
\hline & & 1 & 2 & 3 & 4 & 5 & 6 & & & & \\
\hline \multirow{5}{*}{$63-1$} & $112-1$ & 63.1 & 62.9 & 63.0 & 62.9 & 63.3 & & 63.04 & 63.2 & -0.18 & 0.4 \\
\hline & BCS - 1 & 63.4 & 63.2 & 63.5 & 63.5 & 63.4 & & 63.40 & & +0.18 & 0.3 \\
\hline & $112-2$ & 63.5 & 63.6 & 63.8 & 63.7 & 63.8 & & 63.68 & & +0.46 & 0.3 \\
\hline & BCS -2 & 64.0 & 64.1 & 64.1 & 64.1 & 64.1 & & 64.08 & & +0.86 & 0.1 \\
\hline & MANUFACT & 63.3 & 63.1 & 63.2 & 63.2 & 63.3 & 63.2 & 63.22 & & & 0.2 \\
\hline \multirow[t]{5}{*}{$63-2$} & $112 \cdot 1$ & 63.0 & 61.7 & 62.9 & 62.8 & 62.5 & & 62.58 & 63.1 & -0.52 & 1.3 \\
\hline & BCS -1 & 63.2 & 62.4 & 62.9 & 63.1 & 63.0 & & 62.92 & & -0.18 & 0.8 \\
\hline & $112-2$ & 63.8 & 62.6 & 63.6 & 63.8 & 63.4 & & 63.44 & & +0.34 & 1.2 \\
\hline & BCS -2 & 63.7 & 62.9 & 63.9 & 63.8 & 63.9 & & 63.64 & & +0.54 & 1.0 \\
\hline & MANUFACT & 63.1 & 63.5 & 63.0 & 63.0 & 63.0 & 63.0 & 63.10 & & & 0.5 \\
\hline \multirow[t]{5}{*}{$63-3$} & $112-1$ & 62.6 & 62.7 & 62.5 & 62.5 & 62.5 & & 62.56 & 63.0 & -0.44 & 0.2 \\
\hline & $B C S-1$ & 63.1 & 63.0 & 63.0 & 63.0 & 63.0 & & 63.02 & & +0.02 & 0.1 \\
\hline & $112-2$ & 63.3 & 63.3 & 63.3 & 63.2 & 63.3 & & 63.28 & & +0.28 & 0.1 \\
\hline & BCS -2 & 63.7 & 63.7 & 63.7 & 63.8 & 63.9 & & 63.76 & & +0.76 & 0.2 \\
\hline & MANUFACT & 63.0 & 63.0 & 63.0 & 62.9 & 63.0 & 63.1 & 63.00 & & & 0.2 \\
\hline \multirow[t]{5}{*}{$63-4$} & $112 \cdot 1$ & 62.6 & 62.7 & 62.9 & 63.0 & 62.9 & & 62.82 & 63.0 & -0.23 & 0.4 \\
\hline & BCS - 1 & 63.6 & 63.5 & 63.8 & 63.8 & 63.8 & & 63.70 & & +0.65 & 0.3 \\
\hline & $112-2$ & 64.0 & 64.0 & 63.9 & 64.1 & 63.9 & & 63.98 & & +0.93 & 0.2 \\
\hline & BCS -2 & 64.1 & 64.3 & 64.2 & 64.3 & 64.3 & & 64.24 & & +1.19 & 0.2 \\
\hline & MANUFACT & 63.0 & 63.1 & 63.1 & 63.0 & 63.0 & 63.1 & 63.05 & & & 0.1 \\
\hline \multirow[t]{5}{*}{$63-5$} & $112-1$ & 62.5 & 62.6 & 62.8 & 63.1 & 63.2 & & 62.84 & 63.5 & -0.66 & 0.7 \\
\hline & $B C S-1$ & 63.6 & 63.6 & 63.6 & 63.6 & 63.7 & & 63.62 & & +0.12 & 0.1 \\
\hline & $112-2$ & 64.3 & 64.0 & 64.0 & 64.3 & 64.1 & & 64.14 & & +0.64 & 0.3 \\
\hline & BCS -2 & 64.4 & 64.4 & 64.3 & 64.5 & 64.3 & & 64.38 & & +0.88 & 0.2 \\
\hline & MANUFACT & VAIUES & $S$ NOT & AVAILA & $3 L E$ & & & & & & \\
\hline \multirow[t]{5}{*}{63.6} & $112-1$ & 61.9 & 61.9 & 62.0 & 62.1 & 62.2 & & 62.02 & 62.5 & -0.50 & 0.3 \\
\hline & $B C S \cdot 1$ & 62.3 & 62.3 & 62.3 & 62.3 & 62.4 & & 62.32 & & -0.20 & 0.1 \\
\hline & $112-2$ & 63.2 & 63.1 & 63,2 & 63.2 & 63.2 & & 63.18 & & +0.66 & 0.1 \\
\hline & $B C S \cdot 2$ & 63.2 & 63.2 & 63.1 & 63.2 & 63.2 & & 63.18 & & +0.66 & 0.1 \\
\hline & MANUFACT & 62.5 & 62.5 & 62.5 & 62.5 & 62.5 & 62.6 & 62.52 & & & 0.1 \\
\hline \multirow[t]{5}{*}{$63-7$} & $112-1$ & 59.6 & 59.6 & 59.6 & 59.7 & 59.4 & & 59.58 & 60.6 & -1.05 & 0.3 \\
\hline & $B C S-1$ & 60.0 & 60.3 & 60.2 & 60.1 & 60.2 & & 60.16 & & -0.47 & 0.3 \\
\hline & $112-2$ & 60.5 & 60.6 & 60.3 & 60.2 & 60.3 & & 60.38 & & -0.25 & 0.4 \\
\hline & $B C S-2$ & 60.8 & 60.7 & 60.6 & 60.5 & 60.7 & & 60.66 & & +0.03 & 0.3 \\
\hline & MANUFACT & 60.6 & 60.5 & 60.6 & 60.7 & 60.7 & 60.7 & 60.63 & & & 0.2 \\
\hline
\end{tabular}


Table 5. Results of IMGC Hardness Measurements on Nominally 25 HRC Test Blocks

\begin{tabular}{|c|c|c|c|c|c|c|c|c|c|c|c|}
\hline \multirow[t]{2}{*}{ Block } & \multirow[t]{2}{*}{ Series } & \multicolumn{6}{|c|}{ Measurements* } & \multirow[t]{2}{*}{ Avg } & \multirow{2}{*}{$\begin{array}{l}\text { Assigned } \\
\text { Value }\end{array}$} & \multirow{2}{*}{$\begin{array}{c}\text { Difference } \\
\text { Manufact/NIST }\end{array}$} & \multirow[t]{2}{*}{ Range } \\
\hline & & 1 & 2 & 3 & 4 & 5 & 6 & & & & \\
\hline \multirow[t]{3}{*}{$25-1$} & IMGC 112 & 25.2 & 25.3 & 24.8 & 25.0 & 25.0 & & 25.06 & 24.6 & +0.46 & 0.5 \\
\hline & IMGC C15 & 25.0 & 25.1 & 25.0 & 24.8 & 24.8 & & 24.94 & & +0.34 & 0.3 \\
\hline & MANUFACT & 24.7 & 24.6 & 24.6 & 24.6 & 24.6 & 24.5 & 24.60 & & & 0.2 \\
\hline \multirow[t]{3}{*}{$25-3$} & IMGC 112 & 23.8 & 23.4 & 23.7 & 23.6 & 23.7 & & 23.64 & 23.8 & -0.13 & 0.4 \\
\hline & IMGC C15 & 22.6 & 23.2 & 23.4 & 23.5 & 23.6 & & 23.26 & & -0.51 & 0.4 \\
\hline & MANUFACT & 23.9 & 23.8 & 23.7 & 23.8 & 23.7 & 23.7 & 23.77 & & & 0.2 \\
\hline \multirow[t]{3}{*}{$25-7$} & IMGC 112 & 21.0 & 21.6 & 21.5 & 21.6 & 21.6 & & 21.46 & 21.6 & -0.17 & 0. \\
\hline & IMGC C15 & 21.3 & 21.5 & 21.4 & 21.3 & 21.4 & & 21.38 & & -0.25 & 0 \\
\hline & MANUFACT & 21.7 & 21.7 & 21.6 & 21.4 & 21.7 & 21.7 & 21.63 & & & 0.3 \\
\hline
\end{tabular}

*The reported results of the individual IMGC hardness measurements ranged from whole HRC units to $0.001 \mathrm{HRC}$ unit. The values presented in this table have been rounded to the nearest 0.1 HRC unit. 
Table 6. Results of IMGC Hardness Measurements on Nominally 45 HRC Test Blocks

\begin{tabular}{|c|c|c|c|c|c|c|c|c|c|c|c|}
\hline \multirow[t]{2}{*}{ Block } & \multirow[t]{2}{*}{ Series } & \multicolumn{6}{|c|}{ Measurements* } & \multirow[t]{2}{*}{ Avg } & \multirow{2}{*}{$\begin{array}{l}\text { Assigned } \\
\text { Value }\end{array}$} & \multirow{2}{*}{$\begin{array}{c}\text { Difference } \\
\text { Manufact/NIST }\end{array}$} & \multirow[t]{2}{*}{ Rang } \\
\hline & & 1 & 2 & 3 & 4 & 5 & 6 & & & & \\
\hline \multirow[t]{3}{*}{$45-1$} & IMGC 112 & 45.7 & 45.8 & 45.8 & 45.6 & 45.7 & & 45.72 & 45.0 & +0.72 & 0.2 \\
\hline & IMGC C15 & 45.6 & 45.8 & 45.6 & 45.4 & 45.6 & - & 45.60 & & +0.60 & 0.4 \\
\hline & MANUFACT & 44.9 & 45.0 & 45.0 & 45.0 & 45.1 & 45.0 & 45.00 & & & 0.2 \\
\hline \multirow[t]{3}{*}{$45-3$} & IMGC 112 & 44.5 & 44.5 & 44.7 & 44.7 & 44.7 & & 44.62 & 44.5 & +0.14 & 0.2 \\
\hline & IMGC C15 & 44.3 & 44.2 & 44.5 & 44.4 & 44.5 & & 44.38 & & -0.10 & 0.3 \\
\hline & MANUFACT & 44.6 & 44.4 & 44.5 & 44.4 & 44.6 & 44.4 & 44.48 & & & 0.2 \\
\hline \multirow[t]{3}{*}{$45-7$} & IMGC 112 & 40.2 & 40.4 & 40.5 & 40.5 & 40.4 & & 40.40 & 40.4 & -0.03 & 0 . \\
\hline & IMGC C15 & 39.9 & 40.1 & 40.0 & 40.0 & 40.2 & & 40.04 & & -0.39 & 0. \\
\hline & MANUFACT & 40.4 & 40.5 & 40.6 & 40.3 & 40.4 & 40.4 & 40.43 & & & 0 \\
\hline
\end{tabular}

*The reported results of the individual IMGC hardness measurements ranged from whole HRC units to 0.001 HRC unit. The values presented in this table have been rounded to the nearest 0.1 HRC unit. 
Table 7. Results of IMGC Hardness Measurements on Nominally 63 HRC Test Blocks

\begin{tabular}{|c|c|c|c|c|c|c|c|c|c|c|c|}
\hline \multirow[t]{2}{*}{ Block } & \multirow[t]{2}{*}{ Series } & \multicolumn{6}{|c|}{ Measurements* } & \multirow[t]{2}{*}{ Avg } & \multirow{2}{*}{$\begin{array}{l}\text { Assigned } \\
\text { Value }\end{array}$} & \multirow{2}{*}{$\begin{array}{c}\text { Difference } \\
\text { Manufact/NIST }\end{array}$} & \multirow[t]{2}{*}{ Range } \\
\hline & & 1 & 2 & 3 & 4 & 5 & 6 & & & & \\
\hline \multirow[t]{3}{*}{$63-1$} & IMGC 112 & 64.0 & 64.0 & 64.1 & 64.1 & 64.2 & & 64.08 & 63.2 & +0 & 0.2 \\
\hline & IMGC C15 & 64.5 & 64.4 & 64.3 & 64.2 & 64.3 & & 64.34 & & +1.11 & 0.3 \\
\hline & MANUFACT & 63.3 & 63.1 & 63.2 & 63.2 & 63.3 & 63.2 & 63.22 & & & 0.2 \\
\hline \multirow[t]{3}{*}{$3-3$} & IMGC 112 & 63.9 & 63.7 & 63.9 & 63.8 & 63.8 & & 63.82 & 63.0 & +0.82 & 0.1 \\
\hline & IMGC C15 & 63.9 & 64.0 & 64.0 & 63.9 & 63.9 & & 63.94 & & +0.94 & 0.1 \\
\hline & MANUFACT & 63.0 & 63.0 & 63.0 & 62.9 & 63.0 & 63.1 & 63.00 & & & 0.2 \\
\hline \multirow[t]{3}{*}{$3-7$} & IMGC 112 & 60.7 & 60.7 & 60.8 & 60.8 & 60.7 & & 60.74 & 60.6 & +0.11 & 0.1 \\
\hline & IMGC C15 & 60.8 & 60.9 & 60.8 & 60.9 & 60.8 & & 60.84 & & +0.21 & 0.1 \\
\hline & MANUFACT & 60.6 & 60.5 & 60.6 & 60.7 & 60.7 & 60.7 & 60.63 & & & 0.2 \\
\hline
\end{tabular}

*The reported results of the individual IMGC hardness measurements ranged from whole HRC units to 0.001 HRC unit. The values presented in this table have been rounded to the nearest 0.1 HRC unit. 
Table 8. Results of NIST Hardness Measurements on Nominally 30 HRB Test Blocks

Block Series

30-2 A1

C1

C2

C3

MANUFACT

$30-3 \mathrm{AI}$

C1

$\mathrm{C} 2$

C3

MANUFACT

$30-4$ A.1

C1

- $\mathrm{C} 2$

C3

MANUFACT

$30-5 \quad A 1$

C1

C2

C3

MANUFACT

30-6 A.1

C1

C2

C3

MANUFACT

$30-7 \quad A 1$

C1 2

C3

MANUFACT*

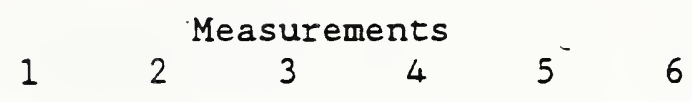

$\begin{array}{lllll}43.3 & 43.9 & 43.7 & 43.7 & 44.0 \\ 43.6 & 44.2 & 42.3 & 43.2 & 43.7 \\ 43.2 & 42.8 & 42.6 & 43.0 & 42.8 \\ 43.5 & 44.2 & 44.0 & 43.8 & 43.8 \\ 39.8 & 39.8 & 39.6 & 40.2 & 40.2\end{array}$

$\begin{array}{lllll}39.8 & 39.8 & 39.6 & 40.2 & 40.2\end{array}$

$\begin{array}{llllll}36.5 & 37.0 & 36.9 & 36.0 & 36.8\end{array}$

$\begin{array}{lllll}35.7 & 37.3 & 36.8 & 35.4 & 36.3\end{array}$

$\begin{array}{lllll}35.3 & 36.0 & 36.0 & 36.4 & 35.3\end{array}$

$\begin{array}{lllll}36.1 & 37.5 & 37.9 & 37.9 & 38.1\end{array}$

$\begin{array}{lllll}33.1 & 33.3 & 33.6 & 33.3 & 32.9\end{array}$

$\begin{array}{lllll}45.0 & 34.0 & 33.6 & 32.8 & 33.2\end{array}$

$\begin{array}{lllll}43.0 & 33.5 & 32.3 & 31.9 & 31.3\end{array}$

$\begin{array}{lllll}35.6 & 32.9 & 32.3 & 32.2 & 32.2\end{array}$

$\begin{array}{lllll}37.1 & 34.4 & 32.5 & 33.3 & 33.2\end{array}$

Values not available

$\begin{array}{lllll}47.4 & 46.7 & 47.4 & 47.1 & 47.4\end{array}$

$\begin{array}{llllll}47.0 & 48.5 & 47.2 & 48.0 & 48.3\end{array}$

$\begin{array}{llllll}47.1 & 48.0 & 46.4 & 47.6 & 47.2\end{array}$

$\begin{array}{llllll}47.9 & 49.1 & 48.8 & 48.6 & 48.6\end{array}$

$\begin{array}{llllll}45.7 & 45.7 & 45.5 & 45.9 & 46.0\end{array}$

$\begin{array}{llllll}40.2 & 40.5 & 40.3 & 40.6 & 40.1\end{array}$

$\begin{array}{lllll}41.0 & 40.9 & 40.9 & 40.8 & 41.2\end{array}$

$\begin{array}{lllll}40.8 & 40.3 & 40.4 & 41.2 & 41.0\end{array}$

$\begin{array}{lllll}41.8 & 41.6 & 41.9 & 42.1 & 42.5\end{array}$

$\begin{array}{lllll}37.9 & 37.6 & 37.8 & 37.5 & 38.1\end{array}$

$\begin{array}{lllll}32.6 & 33.5 & 32.5 & 32.8 & 32.8\end{array}$

$\begin{array}{lllll}33.6 & 34.5 & 33.8 & 34.0 & 33.5\end{array}$

$\begin{array}{lllll}33.4 & 33.6 & 34.0 & 33.9 & 33.6\end{array}$

$\begin{array}{lllll}33.6 & 34.4 & 33.7 & 34.0 & 33.8\end{array}$

$\begin{array}{lllll}34.1 & 34.2 & 34.0 & 34.6 & 34.6\end{array}$

$\begin{array}{lllll}34.0 & 34.1 & 34.1 & 34.3 & 34.7\end{array}$
Avg Assigned
Value $\begin{gathered}\text { Difference } \\ \text { Manufact/NIST }\end{gathered}$ Range

$\begin{array}{llll}43.72 & 39.9 & +3.82 & 0.7 \\ 43.40 & & +3.50 & 1.9 \\ 42.88 & & +2.98 & 0.6 \\ 43.86 & & +3.96 & 0.7 \\ 39.90 & & & 0.6\end{array}$

$39.8 \quad 39.90$

36.64

36.30

35.80

37.50

33.3

$+3.36$

$+3.02$

$+2.52$

$+4.22$

$33.5 \quad 33.28$

35.72

31.2

34.40

33.04

34.10

47.20

47.80

47.26

48.60

46.145 .82

45.8

$+1.98$

$+4.52$

$+3.20$

$+1.84$

$+2.90$

1.0

1.9

1.1

2.0

0.7

12.2

11.7

3.4

4.6

40.34

40.96

40.74

41.98

$38.1 \quad 37.83$

37.8

$+2.51$

$+3.13$

$+2.91$

$+4.15$

0.7

$+1.44$

1.5

1.6

$+2.78$

1. 2

0.6

32.84

34.3

$-1.43$

$-0.39$

$-0.57$

$-0.37$

0.5

0.4

0.9

0.9

0.6

33.70

33.90

34.27

\section{0}

1.0

0.6

0.8

0.7

*Ten measurements made by manufacturer 
Table 9. Results of NIST Hardness Measurements on Nominally 60 HRB Test Blocks

Block Series

$60-1$ A1

C1

C2

C3

MANUFACT

$60-2$ A1

C1

$\mathrm{C} 2$

\section{C3}

MANUFACT

60-3 AI

C1

C2

C3

MANUFACT

$60.4 \quad$ A1

C1

C2

C3

MANUFACT

60-5 A.

C1

$\mathrm{C} 2$

C3

MANUFACT

60-6 A1

C1

$\mathrm{C} 2$

C3

MANUFACT

60-7 A.

C1

C2

C3

MANUFACT $*$

$$
1 \quad 2 \begin{array}{lllll}
\text { Measurements } \\
& 3 & 4 & 5 & 6
\end{array}
$$

$\begin{array}{lllll}61.0 & 61.0 & 61.4 & 61.0 & 61.4\end{array}$

$\begin{array}{lllll}61.3 & 61.8 & 62.0 & 61.9 & 61.8\end{array}$

$\begin{array}{lllll}61.2 & 61.2 & 61.7 & 61.3 & 61.4\end{array}$

$\begin{array}{lllll}61.9 & 62.3 & 62.6 & 61.8 & 62.2\end{array}$

$\begin{array}{lllll}59.0 & 58.5 & 58.7 & 58.5 & 58.5\end{array}$

$\begin{array}{lllll}68.2 & 67.4 & 68.3 & 67.9 & 68.7\end{array}$

$\begin{array}{lllll}67.6 & 67.2 & 68.1 & 68.1 & 68.2\end{array}$

$\begin{array}{lllll}67.5 & 67.4 & 67.4 & 67.9 & 67.9\end{array}$

$\begin{array}{lllll}67.4 & 68.0 & 68.2 & 67.8 & 67.8\end{array}$

$\begin{array}{lllll}66.0 & 65.9 & 66.1 & 66.1 & 66.0\end{array}$

$\begin{array}{lllll}60.1 & 60.3 & 59.8 & 59.7 & 60.2\end{array}$

$\begin{array}{lllll}60.0 & 60.8 & 59.9 & 60.3 & 60.3\end{array}$

$\begin{array}{lllll}60.3 & 59.6 & 59.6 & 60.0 & 58.8\end{array}$

$\begin{array}{llllll}61.1 & 61.6 & 60.6 & 60.5 & 61.2\end{array}$

$\begin{array}{lllll}59.0 & 59.5 & 60.3 & 59.7 & 59.0\end{array}$

$\begin{array}{lllll}62.3 & 61.3 & 60.3 & 60.6 & 60.8\end{array}$

$\begin{array}{lllll}60.2 & 59.7 & 60.8 & 60.9 & 60.7\end{array}$

$\begin{array}{lllll}60.1 & 60.2 & 59.8 & 59.6 & 60.2\end{array}$

$\begin{array}{lllll}61.1 & 61.2 & 60.9 & 61.8 & 60.6\end{array}$

Values not available

$\begin{array}{lllll}64.5 & 65.2 & 64.4 & 64.6 & 64.6\end{array}$

$\begin{array}{lllll}64.6 & 65.6 & 64.5 & 64.8 & 64.7\end{array}$

$\begin{array}{lllll}64.3 & 65.2 & 64.4 & 64.4 & 64.2\end{array}$

$\begin{array}{lllll}64.5 & 65.7 & 64.4 & 65.4 & 65.5\end{array}$

$\begin{array}{lllll}62.8 & 62.9 & 63.0 & 62.8\end{array}$

63.3

$\begin{array}{lllll}64.9 & 64.5 & 64.4 & 64.1 & 65.4\end{array}$

$\begin{array}{lllll}65.3 & 64.2 & 64.4 & 64.7 & 64.8\end{array}$

$\begin{array}{lllll}64.9 & 64.2 & 64.5 & 64.2 & 63.9\end{array}$

$\begin{array}{lllll}65.7 & 65.1 & 65.3 & 65.0 & 66.5\end{array}$

$\begin{array}{lllll}62.1 & 62.3 & 62.4 & 62.6 & 62.3\end{array}$

$\begin{array}{lllll}62.5 & 63.0 & 62.5 & 62.9 & 62.7\end{array}$

$\begin{array}{lllll}62.3 & 62.4 & 62.2 & 62.3 & 62.1\end{array}$

$\begin{array}{lllll}62.3 & 62.5 & 62.2 & 62.5 & 62.2\end{array}$

$\begin{array}{lllll}62.5 & 62.9 & 62.6 & 62.9 & 62.7\end{array}$

$\begin{array}{llllll}62.4 & 62.4 & 62.6 & 62.6 & 62.6\end{array}$

$\begin{array}{lllll}62.4 & 62.5 & 62.5 & 62.6 & 62.7\end{array}$
Avg Assigned Value

Difference Range Manufact/NIST

61.16

61.7 .6

61.36

62.16

$58.1 \quad 58.55$

58.6

$+2.61$

$+3.21$

$+2.81$

$+3.61$

0.4

0.7

0.5

0.8

0.9

$\begin{array}{rrrrr} & 68.10 & 66.0 & +2.12 & 1.3 \\ & 67.84 & & +1.86 & 1.0 \\ & 67.62 & & +1.64 & 0.5 \\ & 67.84 & & +1.86 & 0.8 \\ 65.8 & 65.98 & & & 0.3 \\ & & & & \\ & 60.02 & 59.6 & +0.42 & 0.6 \\ & 60.26 & & +0.66 & 0.9 \\ & 59.66 & & +0.06 & 1.5 \\ & 61.00 & & +1.40 & 1.1 \\ 60.1 & 59.60 & & & 1.3\end{array}$

61.06

60.46

60.2

$+0.86$

$+0.26$

$-0.22$

$+0.92$

2. 0

59.98

61.12

64.66

64.84

64.50

65.10

63.4

63.03

63.0

$+1.63$

$+1.81$

$+1.47$

$+2.07$

1.2

0.6

1. 2

64.66

64.68

64.34

65.52

$62.1 \quad 62.30$

62.3

$+2.36$

$+2.38$

$+2.04$

$+3.22$

0.8

1.1

1.0

1.3

0.6

62.72

62.5

$+0.19$

$-0.27$

$-0.19$

$+0.19$

62.72

62.53
1.3

1. 1

1. 0

1.5

0.5

0.5

0.3

0.3

0.4

0.3

$*$ Ten measurements made by manufacturer 
Table 10. Results of NIST Hardness Measurements on Nominally 93 HRB Test Blocks

Block Series

$93-1$ A1

C1

$\mathrm{C2}$

C3

MANUFACT

$93-2$ AI

C1

$\mathrm{C} 2$

$\mathrm{C3}$

MANUFACT

$93-3 \quad$ AI

$\mathrm{Cl}$

C2

C3

MANUEACT

$93-4 \quad$ Al

C1

$\mathrm{C2}$

C3

MANUFACT

$93 \cdot \xi$ AI

$\mathrm{CI}$

C2

$\mathrm{C} 3$

MANUFACT

A1

C1

C2

$\mathrm{C3}$

MANUFACT

AI

C1

C2

C3

MANUFACT*

$1 \quad 2 \begin{array}{lllll}\text { Measurements } & & & \\ & 3 & 4 & 5 & 6\end{array}$

$\begin{array}{lllll}94.6 & 94.4 & 94.6 & 94.5 & 95.1\end{array}$

$\begin{array}{lllll}95.2 & 94.4 & 95.1 & 94.6 & 95.4\end{array}$

$\begin{array}{lllll}95.1 & 94.2 & 94.9 & 95.4 & 95.0\end{array}$

$\begin{array}{lllll}95.4 & 93.9 & 95.3 & 95.2 & 95.4\end{array}$

$\begin{array}{lllll}93.7 & 94.1 & 94.0 & 93.7 & 93.2\end{array}$

$\begin{array}{lllll}93.9 & 92.0 & 93.8 & 94.0 & 93.9\end{array}$

$\begin{array}{lllll}94.1 & 92.4 & 94.0 & 94.1 & 94.0\end{array}$

$\begin{array}{lllll}93.4 & 92.7 & 94.1 & 94.1 & 94.0\end{array}$

$\begin{array}{lllll}94.1 & 92.8 & 93.9 & 93.8 & 93.9\end{array}$

$\begin{array}{lllll}92.9 & 92.2 & 92.2 & 92.7 & 92.7\end{array}$

$\begin{array}{lllll}96.3 & 95.9 & 96.3 & 95.6 & 95.9\end{array}$

$\begin{array}{lllll}96.1 & 96.0 & 96.2 & 5.7 & 95.7\end{array}$

$\begin{array}{lllll}95.9 & 95.5 & 96.0 & 96.1 & 95.7\end{array}$

$\begin{array}{lllll}95.4 & 95.7 & 96.3 & 95.5 & 95.9\end{array}$

$\begin{array}{lllll}95.7 & 95.8 & 95.9 & 95.8 & 95.9\end{array}$

$\begin{array}{lllll}94.7 & 94.9 & 94.9 & 94.9 & 95.0\end{array}$

$\begin{array}{lllll}94.6 & 95.0 & 94.8 & 94.8 & 94.6\end{array}$

$\begin{array}{lllll}94.5 & 94.8 & 94.7 & 94.6 & 94.6\end{array}$

$\begin{array}{lllll}94.7 & 94.8 & 94.8 & 95.1 & 95.0\end{array}$

Values not available

$\begin{array}{lllll}87.6 & 87.7 & 87.2 & 87.7 & 87.5\end{array}$

$\begin{array}{llllll}88.1 & 87.6 & 87.3 & 87.6 & 87.8\end{array}$

$\begin{array}{llllll}88.4 & 88.4 & 88.0 & 87.3 & 87.5\end{array}$

$\begin{array}{llllll}88.1 & 88.2 & 87.9 & 87.4 & 88.7\end{array}$

$\begin{array}{lllll}86.8 & 87.0 & 86.5 & 86.5 & 86.4\end{array}$

$\begin{array}{lllll}90.6 & 90.8 & 90.9 & 90.9 & 90.9\end{array}$

$\begin{array}{lllll}90.7 & 90.8 & 90.9 & 91.0 & 91.0\end{array}$

$\begin{array}{lllll}91.1 & 90.3 & 90.9 & 90.7 & 90.9\end{array}$

$\begin{array}{lllll}91.0 & 90.9 & 91.1 & 91.2 & 90.8\end{array}$

$\begin{array}{lllll}89.5 & 89.5 & 89.5 & 89.6 & 89.4\end{array}$

$\begin{array}{lllll}94.3 & 94.6 & 94.7 & 94.6 & 94.5\end{array}$

$\begin{array}{lllll}94.9 & 95.0 & 94.7 & 94.5 & 94.4\end{array}$

$\begin{array}{lllll}94.6 & 94.5 & 94.9 & 94.6 & 94.7\end{array}$

$\begin{array}{lllll}93.8 & 94.1 & 94.0 & 94.0 & 94.2\end{array}$

$\begin{array}{lllll}93.6 & 94.1 & 94.0 & 94.2 & 94.2\end{array}$

$\begin{array}{lllll}94.0 & 94.1 & 94.1 & 94.1 & 94.1\end{array}$
Avg Assigned
Value $\begin{gathered}\text { Difference RanufactNIST } \\ \end{gathered}$

94.64

94.94

94.92

95.04

93.5 .93 .70

93.52

93.72

93.66

93.70

$92.9 \quad 92.60$

$$
93.7
$$

$+0.94$

0.7

$+1.24$

$+1.22$

$+1.34$

92.6

$+0.92$

$+1.02$

$+1.06$

$+1.10$

96.00

95.94

95.84

95.76

$96.0 \quad 95.85$

95.9

$+0.15$

$+0.09$

$-0.01$

$-0.09$

94.88

94.76

94.64

94.88

94.0

$+0.88$

$+0.76$

$+0.64$

$+0.88$

1.0

1. 2

1.5

0.9

2.0

1.7

1.4

1. 3

0.7

87.54

86.7

$+0.87$

0.5

87.68

87.92

88.06

$86.8 \quad 86.67$

90.82

90.88

90.78

91.00

$89.7 \quad 89.53$

89.5

$+1.29$

$+1.35$

$+1.25$

$+1.47$

0.7

0.5

0.6

0.9

0.3

$+1.25$

$+1.39$

0.3

0.4

0.3

0.4

94.54

94.70

94.66

94.02

94.0

$+0.49$

$+0.65$

$+0.61$

$-0.03$

94.05
0.8

1.1

1. 3

0.5

0.3

0.3

0.8

0.4

0.3

0.4

0.6

0.4

0.4

0.6

*Ten measurements made by manufacturer 
Table 11. Results of NIST Hardness Measurements on Nominally 46 HR3ON Test Blocks

\begin{tabular}{|c|c|c|c|c|c|c|c|c|c|c|c|}
\hline \multirow[t]{2}{*}{ Block } & \multirow[t]{2}{*}{ Series } & \multicolumn{6}{|c|}{ Measurements } & \multirow[t]{2}{*}{ Avg } & \multirow{2}{*}{$\begin{array}{l}\text { Assigned } \\
\text { Value }\end{array}$} & \multirow{2}{*}{$\begin{array}{c}\text { Difference } \\
\text { Manufact/NIST }\end{array}$} & \multirow[t]{2}{*}{ Range } \\
\hline & & 1 & 2 & 3 & 4 & 5 & 6 & & & & \\
\hline \multirow[t]{4}{*}{$46-1$} & $B C S$ & 44.0 & 43.2 & 45.6 & 44.8 & 44.0 & & 44.32 & 46.4 & -2.06 & 2.4 \\
\hline & $112-1$ & 43.7 & 43.9 & 44.5 & 44.1 & 44.3 & & 44.10 & & -2.28 & 0.8 \\
\hline & $112-2$ & 40.8 & 42.2 & 43.3 & 43.3 & 43.3 & & 42.58 & & -3.80 & 2.5 \\
\hline & MANUFACT & 45.9 & 46.2 & 46.5 & 46.5 & 46.6 & 46.6 & 46.38 & & & 0.7 \\
\hline \multirow[t]{4}{*}{$46-2$} & BCS & 44.1 & 45.2 & 44.2 & 44.8 & 44.3 & & 44.52 & 47.5 & -3.02 & 1.1 \\
\hline & $112-1$ & 44.3 & 45.4 & 44.3 & 44.4 & 44.6 & & 44.60 & & -2.94 & 1.1 \\
\hline & $112-2$ & 44.7 & 44.4 & 43.6 & 43.9 & 44.2 & & 44.16 & & -3.38 & 1.1 \\
\hline & MANUFACT & 47.3 & 47.5 & 47.8 & 47.8 & 47.3 & & 47.54 & & & 0.5 \\
\hline \multirow[t]{4}{*}{$46-3$} & $\mathrm{BCS}$ & 42.3 & 40.9 & 42.4 & 43.1 & 42.5 & & 42.24 & 44.7 & -2.43 & 2.2 \\
\hline & $112-1$ & 42.8 & 41.6 & 42.9 & 43.8 & 43.8 & & 42.98 & & -1.69 & 2.2 \\
\hline & $112-2$ & 42.3 & 41.0 & 42.1 & 43.0 & 42.7 & & 42.22 & & -2.45 & 2.0 \\
\hline & MANUFACT & 44.9 & 44.4 & 44.6 & 44.9 & 44.6 & 44.6 & 44.67 & & & 0.5 \\
\hline \multirow[t]{4}{*}{$46-4$} & $B C S$ & 44.6 & 44.9 & 44.2 & 45.6 & 44.1 & & 44.68 & 46.0 & -1.32 & 1.5 \\
\hline & $112-1$ & 44.0 & 44.9 & 44.0 & 44.8 & 44.4 & & 44.42 & & -1.58 & 0.9 \\
\hline & $112-2$ & 43.8 & 44.6 & 43.5 & 44.3 & 43.9 & & 44.02 & & -1.98 & 1.1 \\
\hline & MANUFACT & 45.9 & 46.0 & 46.1 & 46.0 & 46.1 & 45.9 & 46.00 & & & 0.2 \\
\hline \multirow[t]{4}{*}{$46-5$} & $B C S$ & 43.6 & 44.7 & 45.6 & 45.3 & 46.1 & & 45.06 & 46.5 & -1.42 & 2.5 \\
\hline & $112-1$ & 45.3 & 46.2 & 45.2 & 46.2 & 46.7 & & 45.92 & & -0.56 & 1.5 \\
\hline & $112-2$ & 45.6 & 45.5 & 45.5 & 45.3 & 45.8 & & 45.54 & & -0.94 & 0.5 \\
\hline & MANUFACT & 46.5 & 46.4 & 46.6 & 46.5 & 46.5 & 46.4 & 46.48 & & & 0.2 \\
\hline \multirow[t]{4}{*}{$46-6$} & $B C S$ & 44.2 & 44.7 & 44.7 & 45.1 & 45.1 & & 44.76 & 47.7 & -2.99 & 0.9 \\
\hline & $112-1$ & 45.8 & 45.0 & 46.8 & 45.6 & 45.7 & & 45.78 & & -1.97 & 1.8 \\
\hline & $112-2$ & 45.0 & 44.0 & 45.0 & 45.4 & 45.2 & & 44.92 & & -2.83 & 0.7 \\
\hline & MANUFACT & 47.7 & 47.6 & 47.8 & 47.8 & 47.7 & 47.9 & 47.75 & & & 0.3 \\
\hline \multirow[t]{5}{*}{$46-7$} & $B C S$ & 32.7 & 32.8 & 33.0 & 32.8 & 33.1 & & 32.88 & 36.1 & -3.25 & 0.4 \\
\hline & $112-1$ & 34.1 & 34.6 & 34.3 & 34.6 & 34.6 & & 34.44 & & -1.69 & 0.5 \\
\hline & $112-2$ & 33.6 & 33.8 & 33.5 & 33.3 & 33.5 & & 33.54 & & -2.59 & 0.5 \\
\hline & MANUFACT $* *$ & 35.9 & 36.2 & 36.2 & 36.2 & 36.1 & & & & & \\
\hline & & 36.1 & 36.1 & 36.2 & 36.1 & 36.2 & & 36.13 & & & 0.3 \\
\hline
\end{tabular}

*Ten measurements made by manufacturer 
Table 12. Results of NIST Hardness Measurements on Nominally 64 HR3ON Test Blocks

Block Series

$64-1 \quad 3 C S$

$112-1$

$112-2$

MANUFACI

64-2 BCS

112- 1

$112-2$

MANUEACT

$64-3 \quad B C S$

112-1

112 - 2

MANUFACT

$34-4 \quad 3 C S$

-12- 1

112-2

MANUFACT

$64.5 \quad 3 C S$

112- 1

112-2

MANUEACT

$64-6 \quad 3 C S$

1:2-1

112-2

MANUFACT

$64-7 \quad 3 C S$

112-1

$112-2$

MANUEACT:

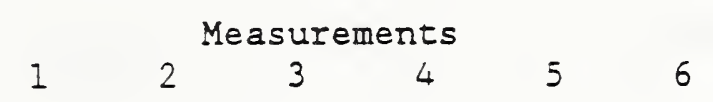

$\begin{array}{llllll}62.0 & 62.7 & 62.8 & 64.1 & 63.0\end{array}$

$\begin{array}{lllll}62.6 & 61.6 & 62.1 & 62.8 & 63.4\end{array}$

$\begin{array}{lllll}61.9 & 61.6 & 61.7 & 62.1 & 63.9\end{array}$

$\begin{array}{llllll}65.3 & 64.9 & 65.3 & 64.7 & 64.6 & 64.6\end{array}$

$65.3 \quad 65.2 \quad 65.5 \quad 65.9 \quad 65.3$

$\begin{array}{lllll}65.2 & 64.4 & 65.3 & 64.7 & 65.2\end{array}$

$\begin{array}{lllll}64.0 & 63.9 & 64.4 & 64.2 & 64.2\end{array}$

$\begin{array}{lllll}66.2 & 65.8 & 66.1 & 66.0 & 65.6\end{array}$

$\begin{array}{llllll}62.7 & 61.7 & 63.0 & 62.7 & 62.5\end{array}$

$\begin{array}{lllll}63.0 & 61.7 & 62.6 & 62.5 & 62.1\end{array}$

$\begin{array}{lllll}62.4 & 61.7 & 62.4 & 61.8 & 61.8\end{array}$

$\begin{array}{lllll}63.8 & 63.8 & 63.9 & 63.8 & 63.8\end{array}$

$\begin{array}{lllll}62.8 & 61.9 & 63.4 & 64.7 & 65.2\end{array}$

$\begin{array}{lllll}65.1 & 64.6 & 64.4 & 64.6 & 64.8\end{array}$

$\begin{array}{lllll}65.0 & 64.4 & 64.3 & 64.3 & 64.5\end{array}$

$\begin{array}{lllll}65.8 & 66.0 & 65.7 & 65.9 & 65.8\end{array}$

$\begin{array}{lllll}62.5 & 63.8 & 63.4 & 63.9 & 63.6\end{array}$

$\begin{array}{lllll}62.6 & 63.5 & 63.3 & 63.5 & 63.4\end{array}$

$\begin{array}{llllll}61.9 & 62.8 & 62.4 & 63.0 & 62.6\end{array}$

$\begin{array}{lllll}64.0 & 64.2 & 64.0 & 64.0 & 64.1\end{array}$

$\begin{array}{llllll}66.4 & 65.8 & 65.7 & 65.8 & 65.6\end{array}$

$\begin{array}{lllll}65.5 & 64.5 & 65.3 & 65.0 & 65.8\end{array}$

$\begin{array}{lllll}64.7 & 65.2 & 65.4 & 65.3 & 65.1\end{array}$

$\begin{array}{lllll}66.8 & 66.8 & 67.0 & 66.8 & 66.9\end{array}$

$\begin{array}{llllll}72.8 & 72.4 & 72.2 & 72.6 & 73.1\end{array}$

$\begin{array}{lllll}72.1 & 72.8 & 72.1 & 72.5 & 72.6\end{array}$

$\begin{array}{lllll}72.0 & 71.8 & 71.9 & 71.9 & 72.9\end{array}$

$\begin{array}{lllll}73.1 & 73.1 & 72.9 & 73.1 & 73.1\end{array}$

$\begin{array}{lllll}73.1 & 73.3 & 73.1 & 73.1 & 73.1\end{array}$

-
Avg Assigned Difference Range
Value Manufact/NIST

62.92

62.50

62.24

64.9

$-1.98$

$-2.40$

$-2.66$

2.1

1.8

64.90

$65.44 \quad 65.9$

$-0.44$

$-0.92$

$-1.74$

64.14

$65.6 \quad 65.88$

62.52

62.38

62.02

$64.0 \quad 63.85$

63.9

$-1.33$

$-1.47$

$-1.83$

2.3

0.7

63.60

64.70

65.8

$-2.23$

$-1.13$

64.50

$-1.33$

0.7

0.9

0.5

0.6

$65.8 \quad 65.83$

$$
63.44
$$

63.26

62.54

$64.1 \quad 64.07$

64.1

$-0.63$

$-0.81$

$-1.53$

1. 3

1. 3

0.7

0.2

65.86

66.9

$-1.02$

$-1.66$

.1 .74

3.3

0.7

0.7

0.3

65.22

65.14

$67.0 \quad 66.88$

72.62

72.42

72.10

73.1

$-0.48$

$-0.68$

$-1.00$

1.4

0.9

1.1

0.2

73.10
0.8

1. 3

0.7

0.2

0.9

0.7

1. 1

0.4

:Ten measurements made by manufacturer 
Table 13. Results of NIST Hardness Measurements on Nominally 80 HR30N Test Blocks

\begin{tabular}{|c|c|c|c|c|c|c|c|c|c|c|c|}
\hline \multirow[t]{2}{*}{ Block } & \multirow[t]{2}{*}{ Series } & \multicolumn{6}{|c|}{ Measurements } & \multirow[t]{2}{*}{ Avg } & \multirow{2}{*}{$\begin{array}{l}\text { Assigned } \\
\text { Value }\end{array}$} & \multirow{2}{*}{$\begin{array}{c}\text { Difference } \\
\text { Manufact/NIST }\end{array}$} & \multirow[t]{2}{*}{ Range } \\
\hline & & 1 & 2 & 3 & 4 & 5 & 6 & & & & \\
\hline \multirow[t]{4}{*}{$80-1$} & $\mathrm{BCS}$ & 80.4 & 80.0 & 80.0 & 80.5 & 80.3 & & 80.24 & 80.5 & -0.26 & 0.5 \\
\hline & $112-1$ & 79.6 & 79.7 & 79.9 & 80.1 & 79.9 & & 79.84 & & -0.66 & 0.5 \\
\hline & $112-2$ & 78.8 & 79.0 & 79.2 & 79.2 & 79.3 & & 79.10 & & -1.40 & 0.5 \\
\hline & MANUFACT & 80.5 & 80.4 & 80.6 & 80.5 & 80.4 & 80.6 & 80.50 & & & 0.2 \\
\hline \multirow[t]{4}{*}{$80-2$} & $\mathrm{BCS}$ & 80.2 & 79.9 & 82.1 & 80.3 & 82.2 & & 80.94 & 79.9 & +1.06 & 2.3 \\
\hline & $112-1$ & 80.6 & 79.9 & 80.1 & 80.2 & 80.0 & & 80.16 & & +0.28 & 0.7 \\
\hline & $112-2$ & 79.0 & 79.1 & 79.3 & 79.5 & 79.5 & & 79.28 & & -0.60 & 0.5 \\
\hline & MANUFACT & 79.8 & 80.0 & 80.0 & 80.0 & 80.0 & 79.5 & 79.88 & & & 0.5 \\
\hline \multirow[t]{4}{*}{$80-3$} & $\mathrm{BCS}$ & 80.3 & 80.2 & 80.3 & 80.1 & 80.5 & & 80.28 & 79.9 & +0.38 & 0.4 \\
\hline & $112-1$ & 79.6 & 79.7 & 79.6 & 79.6 & 79.7 & - & 79.64 & & -0.26 & 0.1 \\
\hline & $112-2$ & 79.2 & 79.6 & 79.3 & 79.4 & 79.2 & & 79.34 & & -0.56 & 0.4 \\
\hline & MANUFACT & 80.0 & 79.7 & 79.9 & 80.0 & 79.9 & 79.9 & 79.90 & & & 0.3 \\
\hline \multirow[t]{4}{*}{$80-4$} & $\mathrm{BCS}$ & 81.3 & 81.3 & 81.7 & 81.7 & 81.2 & & 81.44 & 80.9 & +0.52 & 0.5 \\
\hline & $112-1$ & 81.3 & 81.1 & 80.7 & 80.7 & 80.6 & & 80.88 & & -0.04 & 0.7 \\
\hline & $112-2$ & 80.6 & 80.6 & 80.1 & 80.8 & 80.5 & & 80.52 & & -0.40 & 0.7 \\
\hline & MANUFACT & 81.0 & 80.9 & 80.9 & 80.9 & 80.9 & 80.9 & 80.92 & & & 0.1 \\
\hline \multirow[t]{4}{*}{$80-5$} & $B C S$ & 78.2 & 80.0 & 80.5 & 81.2 & 81.2 & & 80.22 & 82.0 & -1.78 & 3.0 \\
\hline & $112-1$ & 81.4 & 81.2 & 81.1 & 81.3 & 81.3 & & 81.26 & & -0.74 & 0.3 \\
\hline & $112-2$ & 80.3 & 80.4 & 81.1 & 81.0 & 81.0 & & 80.76 & & -1.24 & 0.8 \\
\hline & MANUFACT & 82.1 & 81.9 & 81.9 & 82.1 & 82.0 & 82.0 & 82.00 & & & 0.2 \\
\hline \multirow[t]{4}{*}{$80-6$} & $B C S$ & 80.7 & 80.4 & 80.2 & 80.6 & 80.6 & & 80.50 & 80.9 & -0.43 & 0.5 \\
\hline & $112-1$ & 80.2 & 80.6 & 80.2 & 80.1 & 80.1 & & 80.24 & & -0.69 & 0.5 \\
\hline & $112-2$ & 79.4 & 79.8 & 79.8 & 79.5 & 80.0 & & 79.70 & & -1.23 & 0.6 \\
\hline & MANUFACT & 81.0 & 81.0 & 80.9 & 80.9 & 81.0 & 80.8 & 80.93 & & & 0.2 \\
\hline \multirow[t]{5}{*}{$80-7$} & $\mathrm{BCS}$ & 80.8 & 81.2 & 80.8 & 81.1 & 81.3 & & 81.04 & 81.4 & -0.35 & 0.5 \\
\hline & $112-1$ & 81.4 & 80.6 & 81.4 & 80.9 & 81.1 & & 81.08 & & -0.31 & 0.8 \\
\hline & $112-2$ & 80.1 & 80.1 & 80.7 & 80.7 & 80.3 & & 80.38 & & -1.01 & 0.6 \\
\hline & MANUFACT* & 81.3 & 81.4 & 81.5 & 81.4 & 81.4 & & & & & \\
\hline & & 81.3 & 81.3 & 81.5 & 81.3 & 81.5 & & 81.39 & & & 0.2 \\
\hline
\end{tabular}

*Ten measurements made by manufacturer 
Table 14. Results of NIST Hardness Measurements on Nominally 36 HR30T Test Blocks

\section{Biock Series}

$36.2 \quad C 1$

$\mathrm{C} 2$

C3

MANUFACT

$36-3 \quad C 1$

. $\mathrm{C2}$

C3

MANUFACI

$36-4 \quad \mathrm{Cl}$

$\mathrm{C} 2$

C3

MANUFACT

$36.5 \quad C 1$

$c 2$

C3

MANUFACT

$36-6 \quad C 1$

$\mathrm{C} 2$

C3

MANUFACT

$36-7 \quad C 1$

C2

C3

MANUFACT*

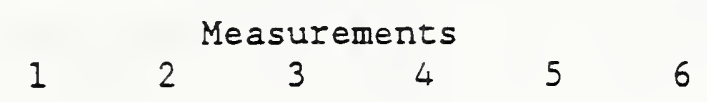

$\begin{array}{lllll}43.6 & 41.0 & 42.8 & 42.7 & 43.7\end{array}$

$\begin{array}{lllll}43.9 & 41.6 & 43.4 & 42.3 & 44.0\end{array}$

$\begin{array}{lllll}42.7 & 41.1 & 41.5 & 43.6 & 42.8\end{array}$

$\begin{array}{lllll}43.3 & 42.4 & 42.4 & 43.3\end{array}$

$\begin{array}{lllll}40.0 & 39.7 & 39.2 & 39.7 & 38.1\end{array}$

$\begin{array}{lllll}39.8 & 40.0 & 39.4 & 40.2 & 38.4\end{array}$

$\begin{array}{lllll}40.0 & 41.4 & 39.5 & 39.7 & 39.9\end{array}$

$\begin{array}{lllll}40.0 & 40.6 & 40.4 & 40.0 & 40.1\end{array}$

$\begin{array}{lllll}27.6 & 28.0 & 28.2 & 28.5 & 31.5\end{array}$

$\begin{array}{lllll}27.9 & 28.3 & 27.6 & 28.0 & 27.6\end{array}$

$\begin{array}{lllll}27.1 & 34.8 & 28.2 & 27.8 & 32.7\end{array}$

Values not available

$\begin{array}{llll}42.7 & 43.1 & 42.7 & 42.7\end{array}$

$\begin{array}{llll}42.0 & 42.2 & 41.9 & 41.7\end{array}$

42.3

42.3

$\begin{array}{lllll}43.4 & 42.3 & 42.3 & 42.9 & 43.0\end{array}$

$\begin{array}{lllll}43.8 & 44.1 & 44.1 & 43.9 & 44.0\end{array}$

$\begin{array}{lllll}42.7 & 40.6 & 42.6 & 42.3 & 43.5\end{array}$

$\begin{array}{lllll}42.5 & 42.0 & 43.2 & 41.9 & 43.0\end{array}$

$\begin{array}{lllll}41.5 & 41.8 & 41.2 & 42.9 & 41.8\end{array}$

$\begin{array}{llllll}42.6 & 42.9 & 42.6 & 42.9 & 42.8\end{array}$

$\begin{array}{lllll}41.7 & 41.4 & 41.2 & 41.3 & 41.1\end{array}$

$\begin{array}{lllll}40.7 & 40.6 & 40.3 & 40.3 & 40.6\end{array}$

$\begin{array}{lllll}40.5 & 40.8 & 38.2 & 42.3 & 42.2\end{array}$

$\begin{array}{lllll}42.8 & 42.8 & 42.7 & 43.5 & 43.6\end{array}$

$\begin{array}{lllll}42.9 & 43.0 & 43.1 & 43.3 & 43.3\end{array}$
Avg Assigned
Value Manference Range

42.76

43.04

42.34

$42.8 \quad 42.83$

$39.34 \quad 40.2$

39.56

40.10

$40.3 \quad 40.23$

28.76

27.88

30.12

$42.70 \quad 44.0$

42.02

42.78

43.98

42.34

42.52

41.84

$42.7 \quad 42.75$

30.9

$-2.14$

$-3.02$

$-0.78$

2.7

2.4

2.5

0.9

$-0.89$

$-0.67$

$-0.13$

1.9

1.8

1,9

0.6

3.9

0.7

7.7

$-1.28$

$-1.96$

$-1.20$

0.8

0.6

1.1

0.3

42.9

$-0.41$

2.9

$-0.23$

1.3

$\begin{array}{ll}-0.91 & 1.7\end{array}$

0.3

41.34

40.50

40.80

$-1.76$

$-2.60$

$-2.30$

43.10
0.6

0.4

4.1

0.9

*Ten measurements made by manufacturer 
Table 15. Results of NIST Hardness Measurements on Nominally 56 HR30T Test Blocks

\begin{tabular}{|c|c|c|c|c|c|c|c|c|c|c|c|}
\hline \multirow[t]{2}{*}{ Block } & \multirow[t]{2}{*}{ Series } & \multicolumn{6}{|c|}{ Measurements } & \multirow[t]{2}{*}{ Avg } & \multirow{2}{*}{$\begin{array}{l}\text { Assigned } \\
\text { Value }\end{array}$} & \multirow{2}{*}{$\begin{array}{l}\text { Difference } \\
\text { Manufact/NIST }\end{array}$} & \multirow[t]{2}{*}{ Range } \\
\hline & & 1 & 2 & 3 & 4 & 5 & 6 & & & & \\
\hline \multirow[t]{4}{*}{$56-1$} & $\mathrm{Cl}$ & 49.4 & 50.5 & 52.2 & 51.0 & 52.6 & & 51.14 & 52.1 & -0.98 & 3.2 \\
\hline & $\mathrm{C2}$ & 50.1 & 48.8 & 52.5 & 51.6 & 51.4 & & 50.88 & & -1.24 & 3.7 \\
\hline & C3 & 50.6 & 50.4 & 50.9 & 51.8 & 51.1 & & 50.96 & & -1.16 & 1.4 \\
\hline & MANUFACT & 52.3 & 52.3 & 51.9 & 51.9 & 52.0 & 52.3 & 52.12 & & & 0.4 \\
\hline \multirow[t]{4}{*}{$56-2$} & $\mathrm{Cl}$ & 56.8 & 56.3 & 56.1 & 57.1 & 56.8 & & 56.62 & 57.5 & -0.88 & 1.0 \\
\hline & $\mathrm{C} 2$ & 58.3 & 57.8 & 58.8 & 58.0 & 57.3 & & 58.04 & & +0.54 & 1.5 \\
\hline & C3 & 57.1 & 56.9 & 55.9 & 57.1 & 57.8 & & 56.96 & & -0.54 & 1.9 \\
\hline & MANUFACT & 57.2 & 57.2 & 57.5 & 57.7 & 57.7 & 57.7 & 57.50 & & & 0.5 \\
\hline \multirow[t]{4}{*}{$56-3$} & $\mathrm{Cl}$ & 55.2 & 56.1 & 56.2 & 56.0 & 56.6 & & 56.02 & 56.6 & -0.60 & 1.4 \\
\hline & $\mathrm{C} 2$ & 56.1 & 55.7 & 56.3 & 56.0 & 57.1 & & 56.24 & & -0.38 & 1.4 \\
\hline & C3 & 55.5 & 55.4 & 55.0 & 55.6 & 56.4 & & 55.58 & & -1.04 & 1.4 \\
\hline & MANUFACT & 56.7 & 56.6 & 56.3 & 56.6 & 56.5 & 57.0 & 56.62 & & & 0.7 \\
\hline \multirow[t]{4}{*}{$56-4$} & $\mathrm{Cl}$ & 54.5 & 55.1 & 55.3 & 55.8 & 56.3 & & 55.40 & 57.0 & -1.60 & 1.8 \\
\hline & $\mathrm{C} 2$ & 55.4 & 55.7 & 55.1 & 56.6 & 56.3 & & 55.82 & & -1.18 & 1.5 \\
\hline & C3 & 54.5 & 56.1 & 55.2 & 57.4 & 56.5 & & 55.94 & & -1.06 & 2.9 \\
\hline & MANUFACT & Values & 5 not & availa & le & & & & & & \\
\hline \multirow[t]{4}{*}{$56-5$} & $\mathrm{Cl}$ & 65.3 & 67.4 & 67.1 & 67.3 & 67.4 & & 66.90 & 68.0 & -1.15 & 2.1 \\
\hline & $\mathrm{C} 2$ & 66.4 & 67.2 & 67.0 & 67.0 & 67.0 & $\therefore$ & 66.92 & & -1.13 & 0.8 \\
\hline & C3 & 67.3 & 66.2 & 67.0 & 67.3 & 67.6 & & 67.08 & & -0.97 & 1.4 \\
\hline & MANUFACT & 67.9 & 67.9 & 68.1 & 68.2 & 68.0 & 68.2 & 68.05 & & & 0.3 \\
\hline \multirow[t]{4}{*}{$56-6$} & $\mathrm{Cl}$ & 57.5 & 57.4 & 58.8 & 57.5 & 59.7 & & 58.18 & 57.9 & +0.23 & 2.2 \\
\hline & $C 2$ & 56.6 & 57.2 & 58.4 & 57.7 & 58.8 & & 57.74 & & -0.21 & 2.2 \\
\hline & C3 & 57.8 & 57.0 & 57.0 & 57.7 & 58.1 & & 57.52 & & -0.43 & 1.1 \\
\hline & MANUFACT & 58.0 & 57.8 & 57.8 & 57.8 & 58.1 & 58.2 & 57.95 & & & 0.4 \\
\hline \multirow[t]{5}{*}{$56-7$} & $\mathrm{Cl}$ & 61.9 & 61.8 & 62.2 & 61.9 & 62.2 & & 62.00 & 62.8 & -0.84 & 0.4 \\
\hline & $\mathrm{C2}$ & 61.4 & 61.4 & 61.3 & 61.2 & 60.8 & & 61.22 & & -1.62 & 0.6 \\
\hline & C3 & 62.0 & 61.7 & 61.7 & 62.7 & 62.2 & & 62.06 & & -0.78 & 1.0 \\
\hline & MANUFACT $*$ & 62.7 & 62.8 & 62.5 & 62.7 & 62.8 & & & & & \\
\hline & & 62.6 & 63.2 & 62.7 & 63.3 & 63.1 & & 62.84 & & & 0.8 \\
\hline
\end{tabular}

$\because$ Ten measurements made by manufacturer 
Table 16. Results of NIST Hardness Measurements on Nominally 78 HR30T Test Blocks

Block Series

$78-1 \quad \mathrm{Cl}$

$\mathrm{C} 2$

C3

MANUFACT

$78-2 \mathrm{Cl}$

$\mathrm{C} 2$

C3

MANUFACT

$78-3 \quad C 1$

$\mathrm{C} 2$

C3

MANUFACT

$78-4 \quad C 1$

$\mathrm{C} 2$

C3

MANUFACT

$78-5 \mathrm{Cl}$

$\mathrm{C} 2$

C3

MANUFACT

$78.6 \mathrm{Cl}$

$\mathrm{C} 2$

C3

MANUFACT

$78-7 \mathrm{Cl}$

$\mathrm{C} 2$

C3

MANUFACT:

$$
1 \quad 2 \begin{array}{llll}
\text { Measurements } \\
3 & 4 & 5 & 6
\end{array}
$$

$\begin{array}{llllll}78.4 & 76.3 & 77.1 & 77.1 & 77.0\end{array}$

$\begin{array}{lllll}77.4 & 76.4 & 77.2 & 77.2 & 77.4\end{array}$

$\begin{array}{lllll}78.8 & 77.3 & 76.7 & 79.5 & 77.6\end{array}$

$\begin{array}{lllll}77.2 & 77.4 & 76.9 & 77.6 & 77.0\end{array}$

$\begin{array}{lllll}78.5 & 78.4 & 78.0 & 78.3 & 78.3\end{array}$

$\begin{array}{llllll}78.5 & 79.0 & 78.8 & 78.8 & 78.8\end{array}$

$\begin{array}{llllll}78.9 & 78.5 & 78.1 & 78.6 & 78.5\end{array}$

$\begin{array}{llllll}78.7 & 78.9 & 79.0 & 78.9 & 78.9\end{array}$

$\begin{array}{lllll}80.3 & 80.3 & 80.9 & 81.0 & 81.2\end{array}$

$\begin{array}{llllll}81.0 & 81.1 & 81.1 & 80.7 & 80.9\end{array}$

$\begin{array}{llllll}81.2 & 81.4 & 80.6 & 80.8 & 81.4\end{array}$

$\begin{array}{lllll}80.2 & 80.2 & 80.2 & 80.4 & 80.7\end{array}$

$\begin{array}{lllll}80.1 & 76.9 & 77.1 & 76.9 & 77.2\end{array}$

$\begin{array}{lllll}76.7 & 76.9 & 77.0 & 76.8 & 77.0\end{array}$

$\begin{array}{lllll}77.3 & 77.0 & 77.3 & 77.9 & 76.8\end{array}$

values not available

$\begin{array}{lllll}79.9 & 79.9 & 80.3 & 80.1 & 80.1\end{array}$

$\begin{array}{llllll}80.0 & 79.9 & 79.6 & 80.1 & 80.1\end{array}$

$\begin{array}{lllll}80.0 & 79.4 & 79.9 & 80.4 & 80.3\end{array}$

$\begin{array}{lllll}79.9 & 79.7 & 79.9 & 79.9 & 79.7\end{array}$

$\begin{array}{lllll}76.1 & 74.5 & 74.3 & 74.8 & 74.8\end{array}$

$\begin{array}{lllll}74.2 & 74.2 & 74.0 & 73.8 & 75.2\end{array}$

$\begin{array}{lllll}74.6 & 74.5 & 74.3 & 75.3 & 74.7\end{array}$

$\begin{array}{lllll}74.5 & 74.2 & 74.2 & 74.2 & 74.2\end{array}$

$\begin{array}{lllll}81.1 & 80.6 & 81.0 & 81.5 & 81.1\end{array}$

$\begin{array}{llllll}78.2 & 79.6 & 80.7 & 80.5 & 80.4\end{array}$

$\begin{array}{llllll}81.2 & 80.5 & 81.6 & 81.9 & 82.4\end{array}$

$\begin{array}{lllll}80.0 & 80.0 & 80.2 & 80.0 & 80.0\end{array}$

$\begin{array}{lllll}79.8 & 80.0 & 80.2 & 80.3 & 80.0\end{array}$
Avg Assigned Value Difference Range
Manufact/NIST

77.18

77.12

77.98

$76.8 \quad 77.15$

77.2

$+0.03$

$-0.03$

$+0.83$

2.1

1.0

2. 8

0.8

78.30

78.78

78.52

$\begin{array}{ll}78.8 & 78.87\end{array}$

78.9

$-0.57$

.0 .09

$-0.35$

80.74

80.96

81.08

$80.8 \quad 80.42$

77.64

76.88

77.26

77.0

$-0.12$

$+0.26$

0.5

0.5

0.8

0.3

80.4

$+0.32$

$+0.54$

$+0.66$

0.9

0.4

0.8

0.6

3.2

0.3

1.1

80.06

79.94

80.00

$\begin{array}{ll}79.8 & 79.82\end{array}$

79.8

$+0.24$

$+0.12$

$+0.18$

0.4

0.5

1. 0

0.2

74.90

74.3

$+0.65$

$+0.03$

$+0.43$

1.8

1.4

1. 0

0.3

74.25

81.06

79.88

81.52

80.0

$+1.01$

0.9

$-0.17$

2.5

$+1.47$

1.9

80.05

0.5

*Ten measurements made by manufacturer 


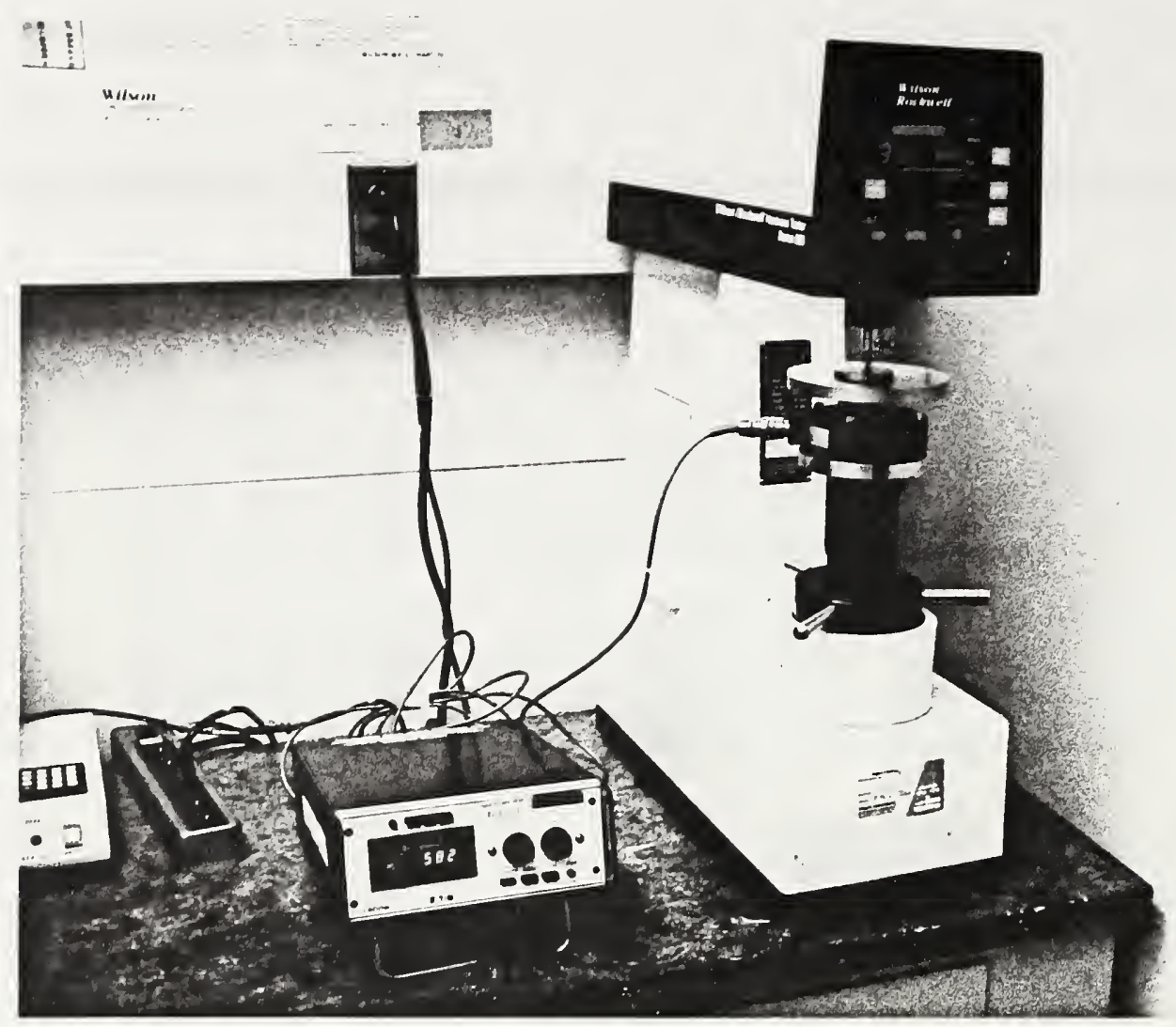

Figure 1. NIST hardness measurement set-up showing load cell and anvil in place.

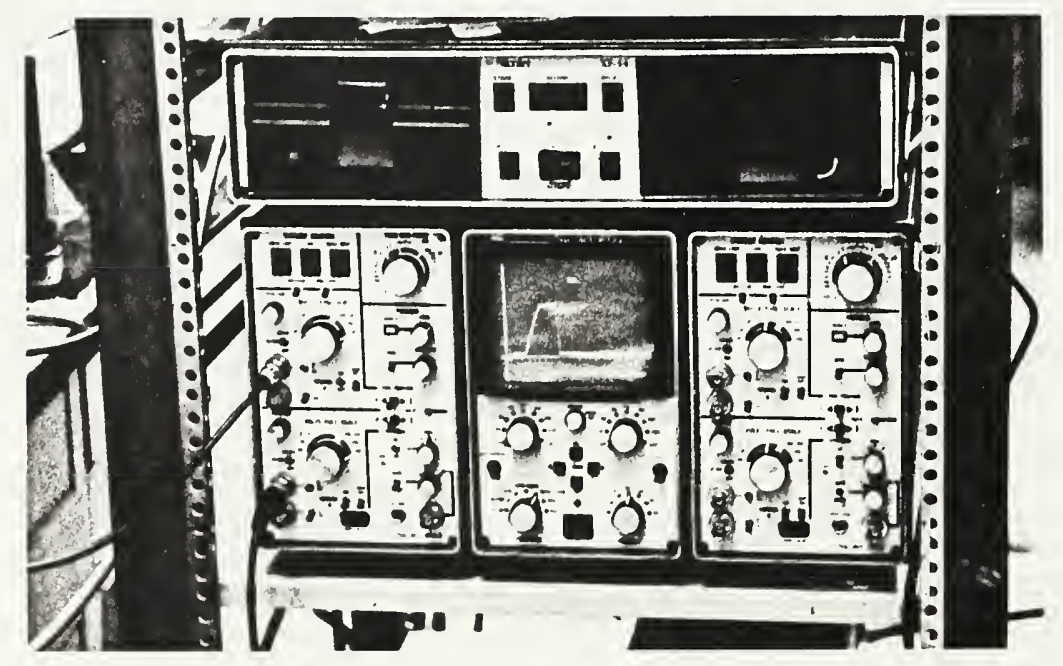

Figure 2. Recording oscilloscope. 


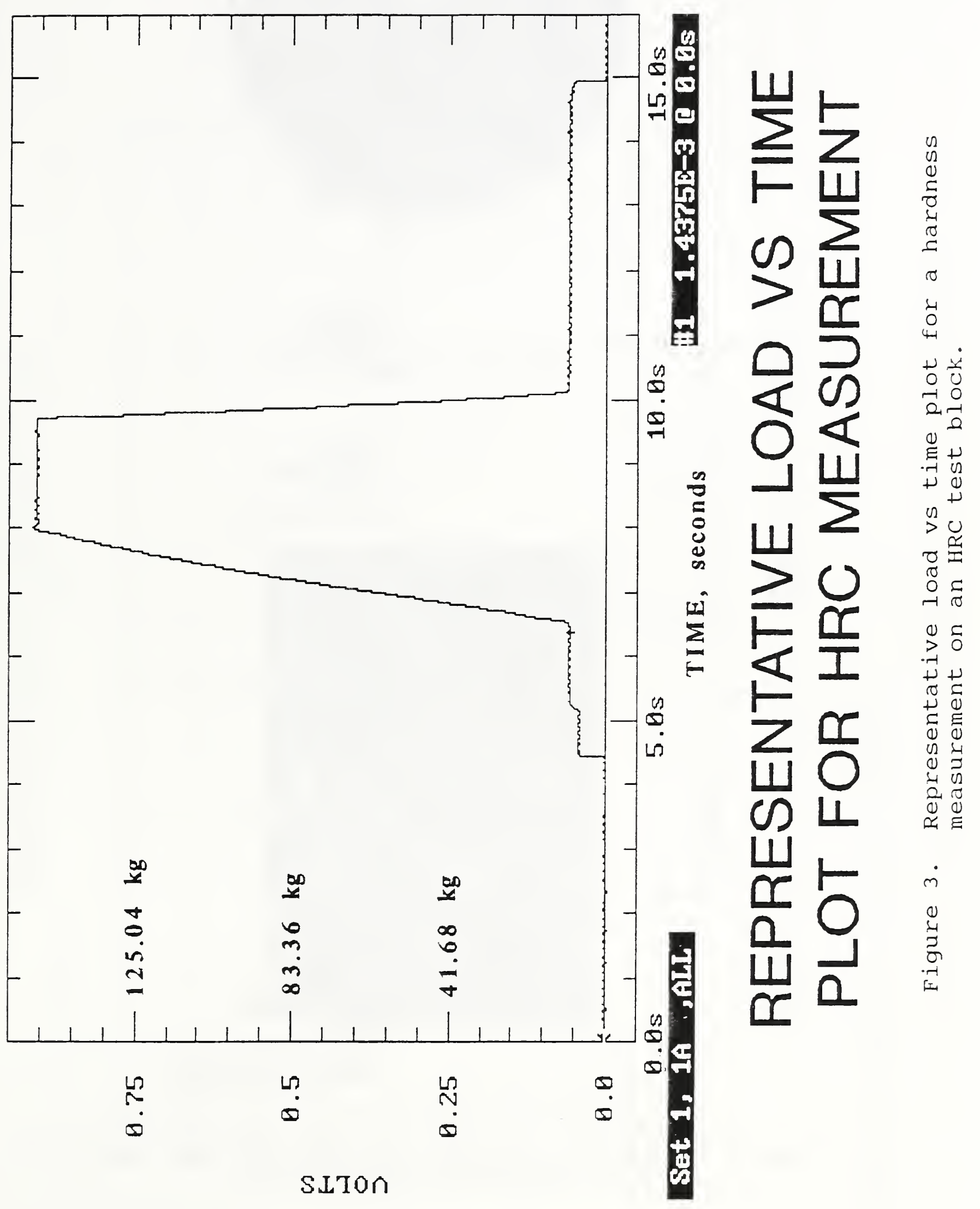




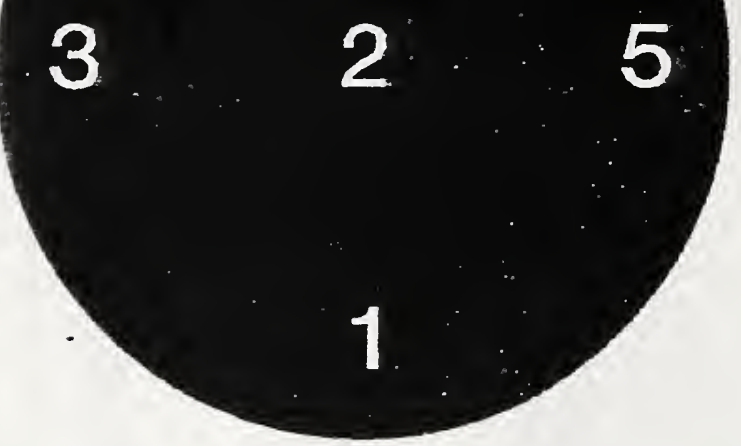

Figure 4. Pattern of measurement locations for round test blocks.

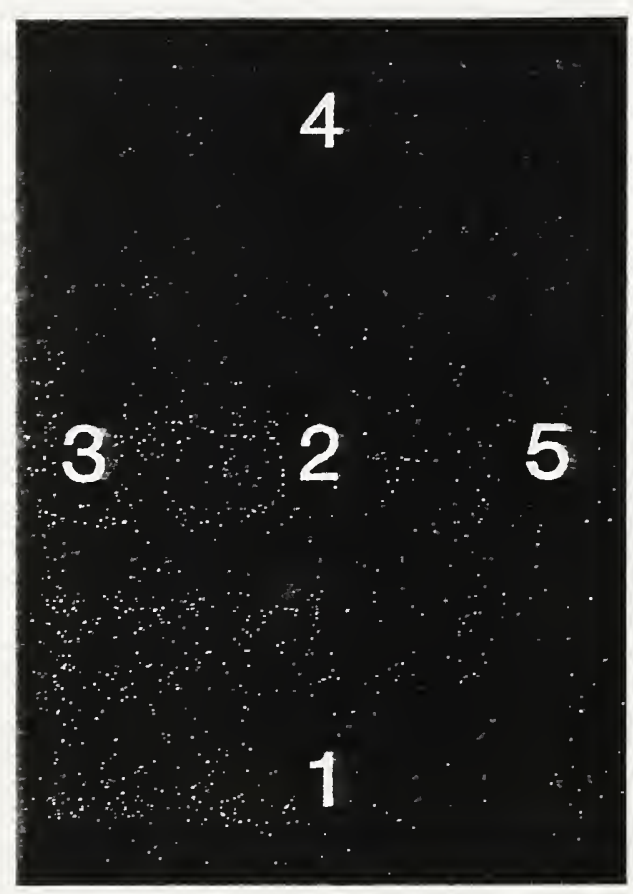

Figure 5. Pattern of measurement locations for square and rectangular test blocks. 

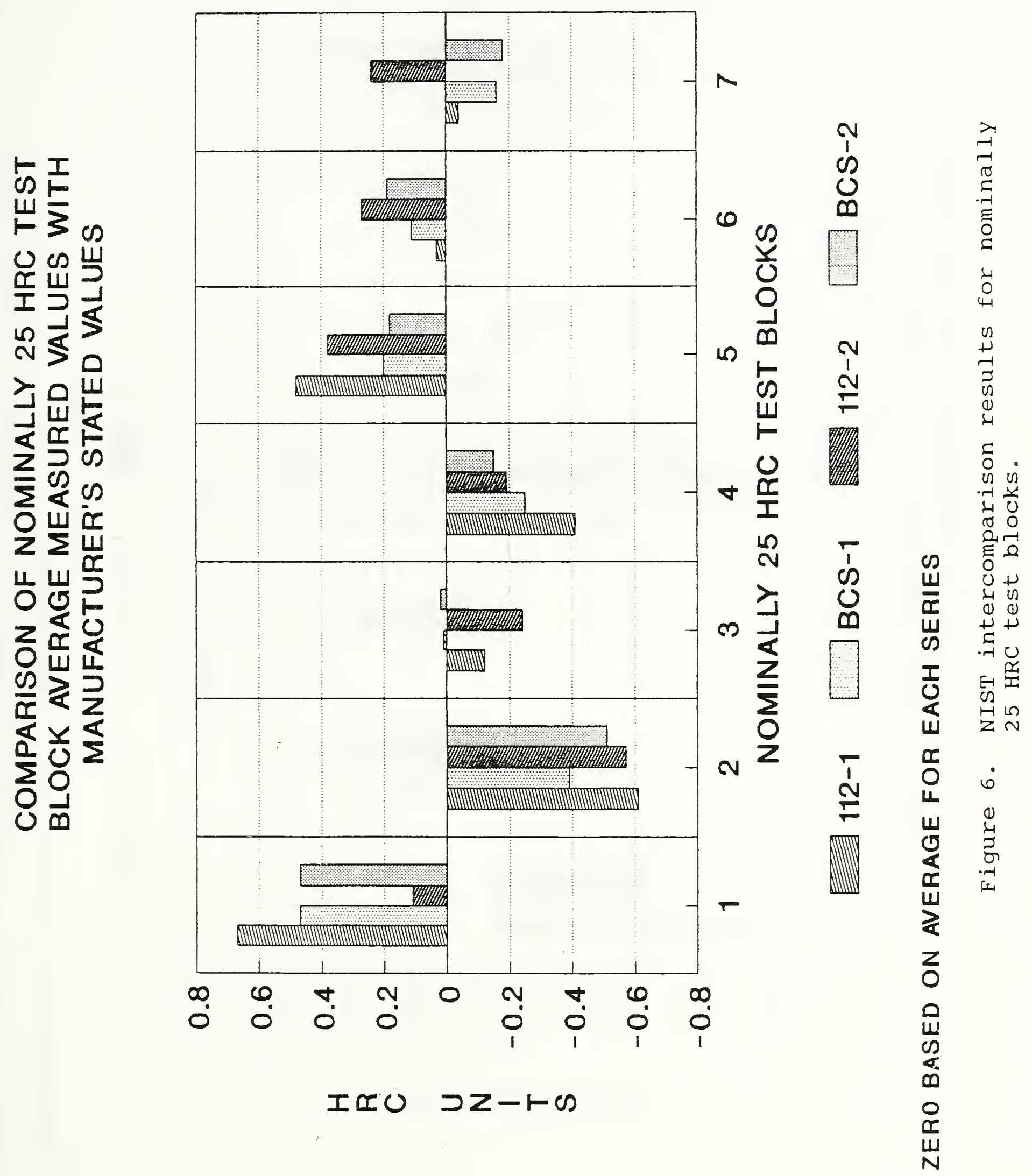

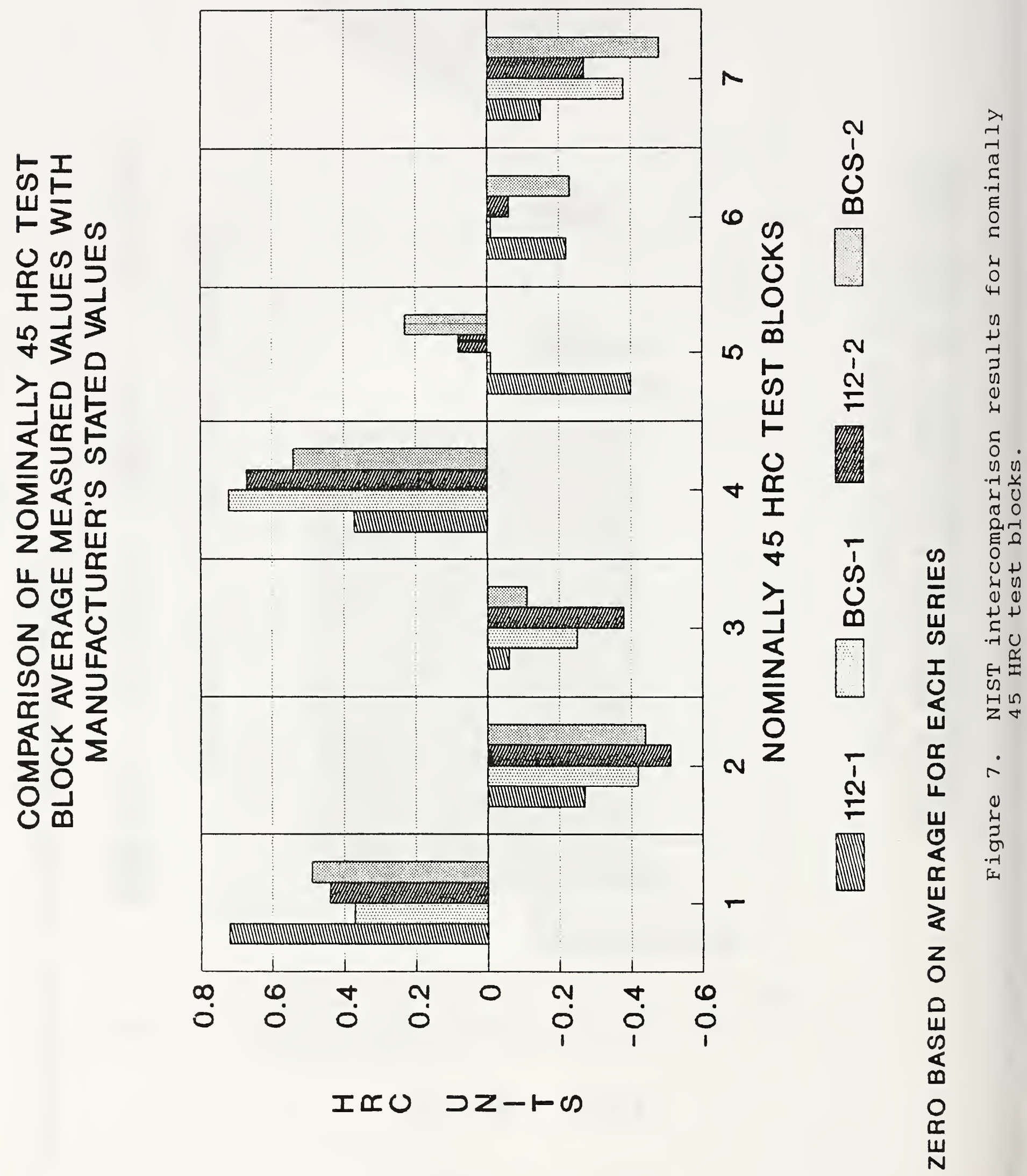


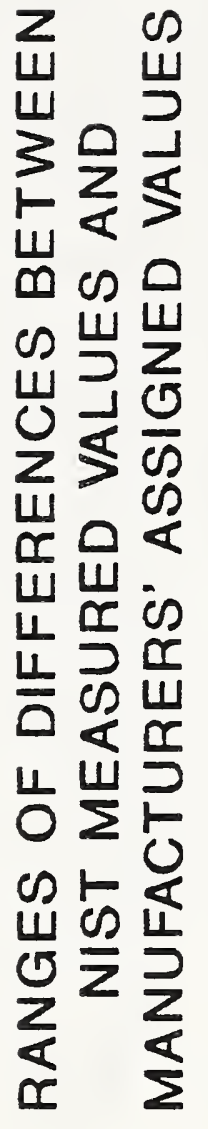

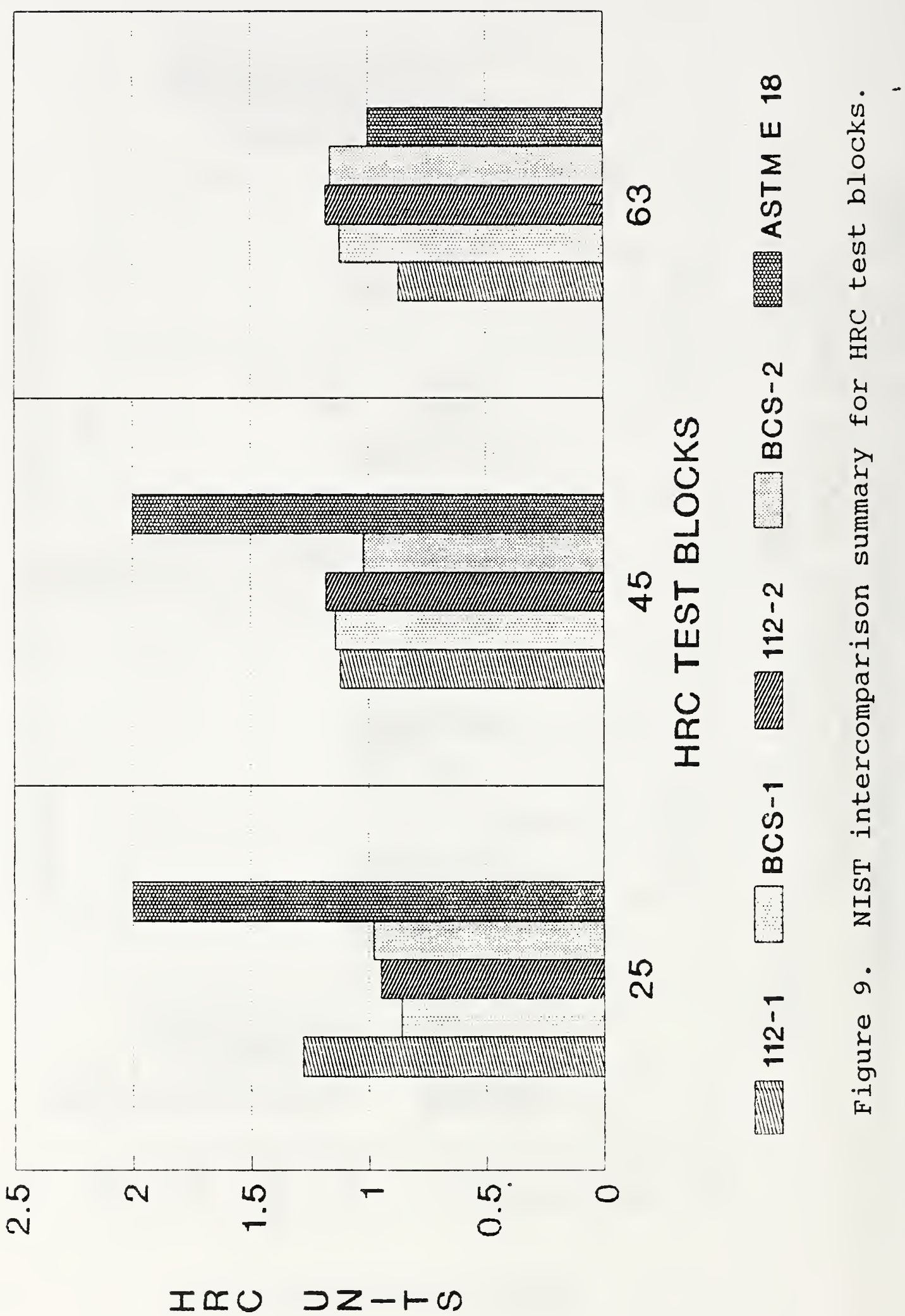




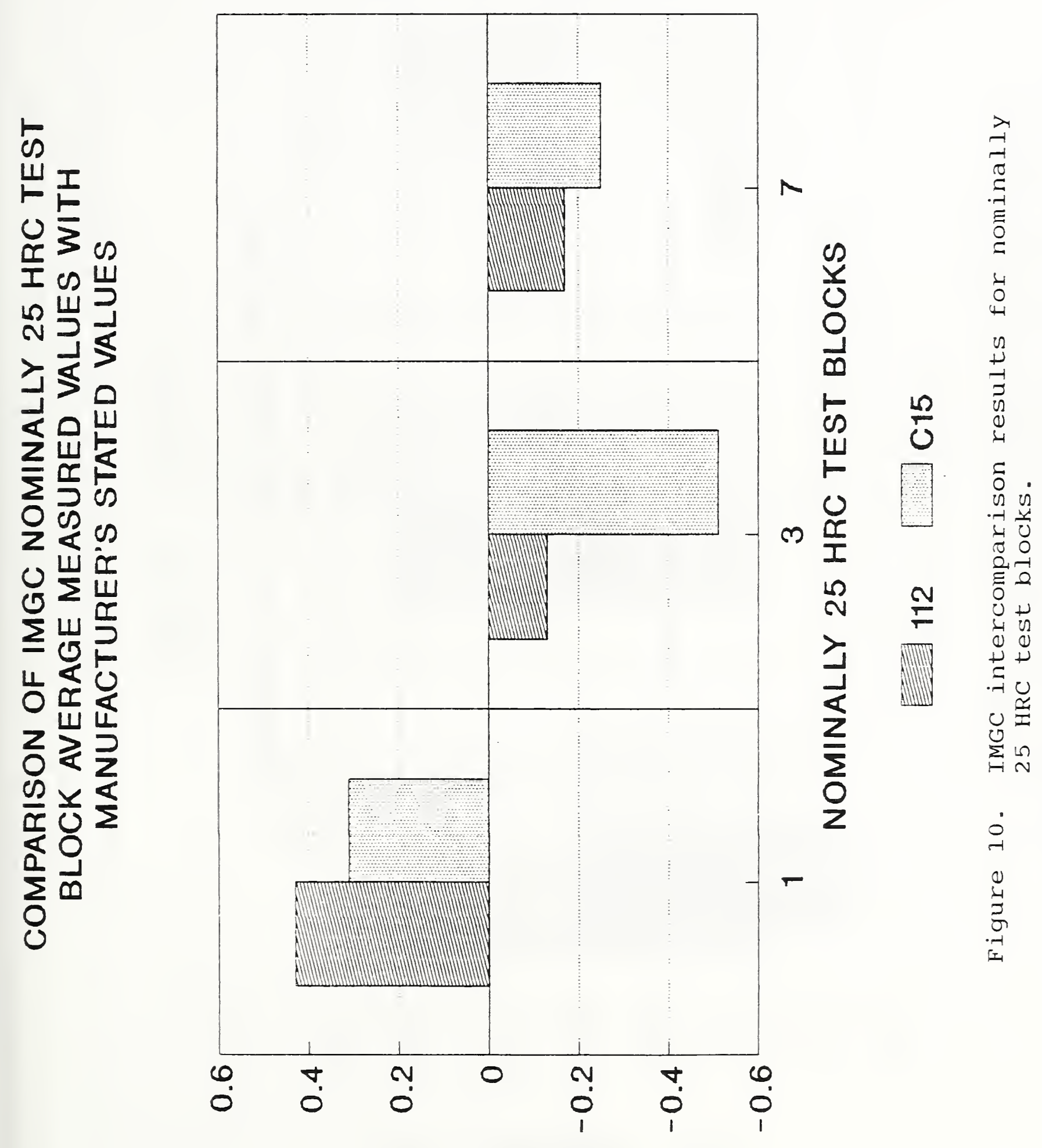

IロU つZートル 

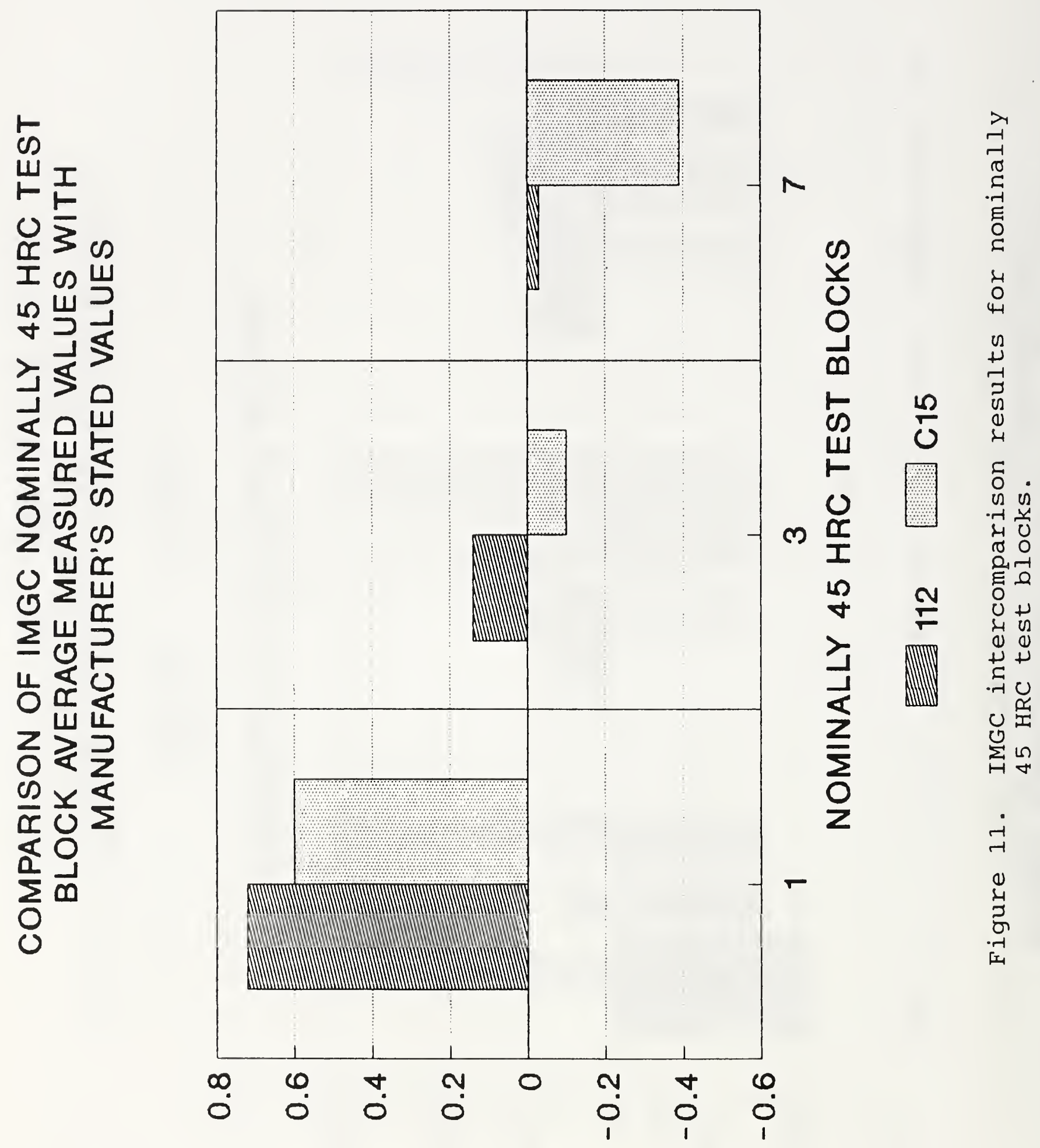

エロO コスートの 


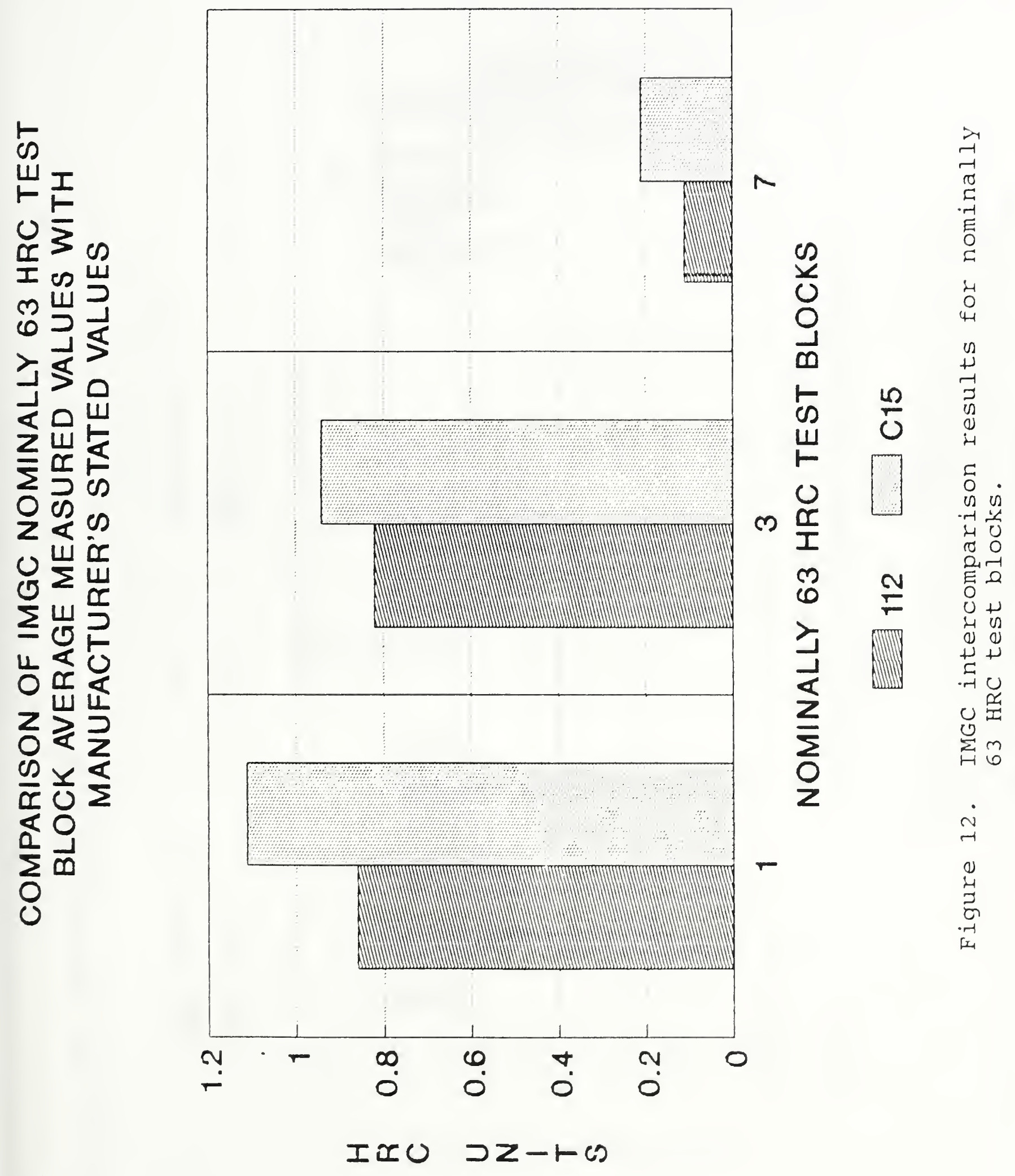



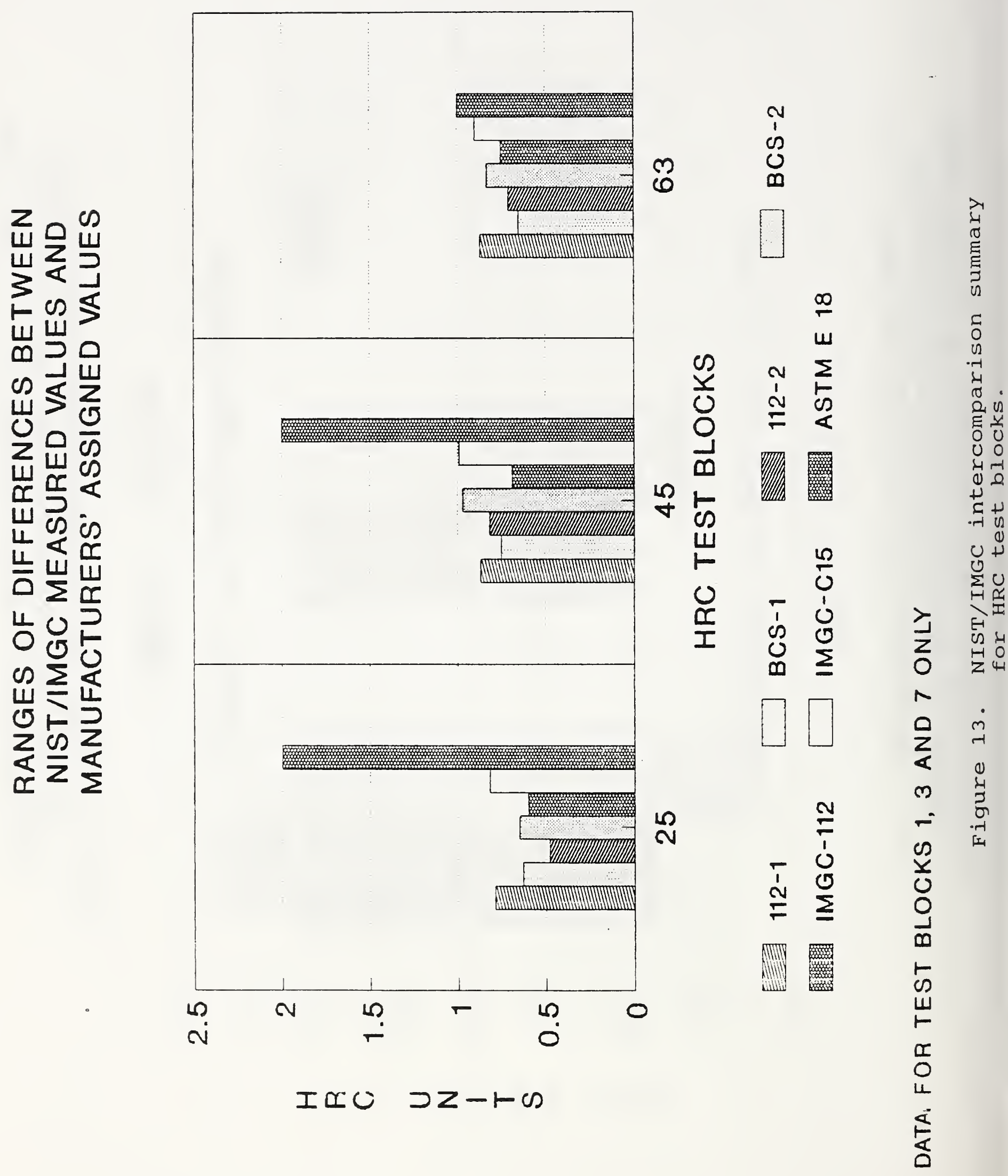

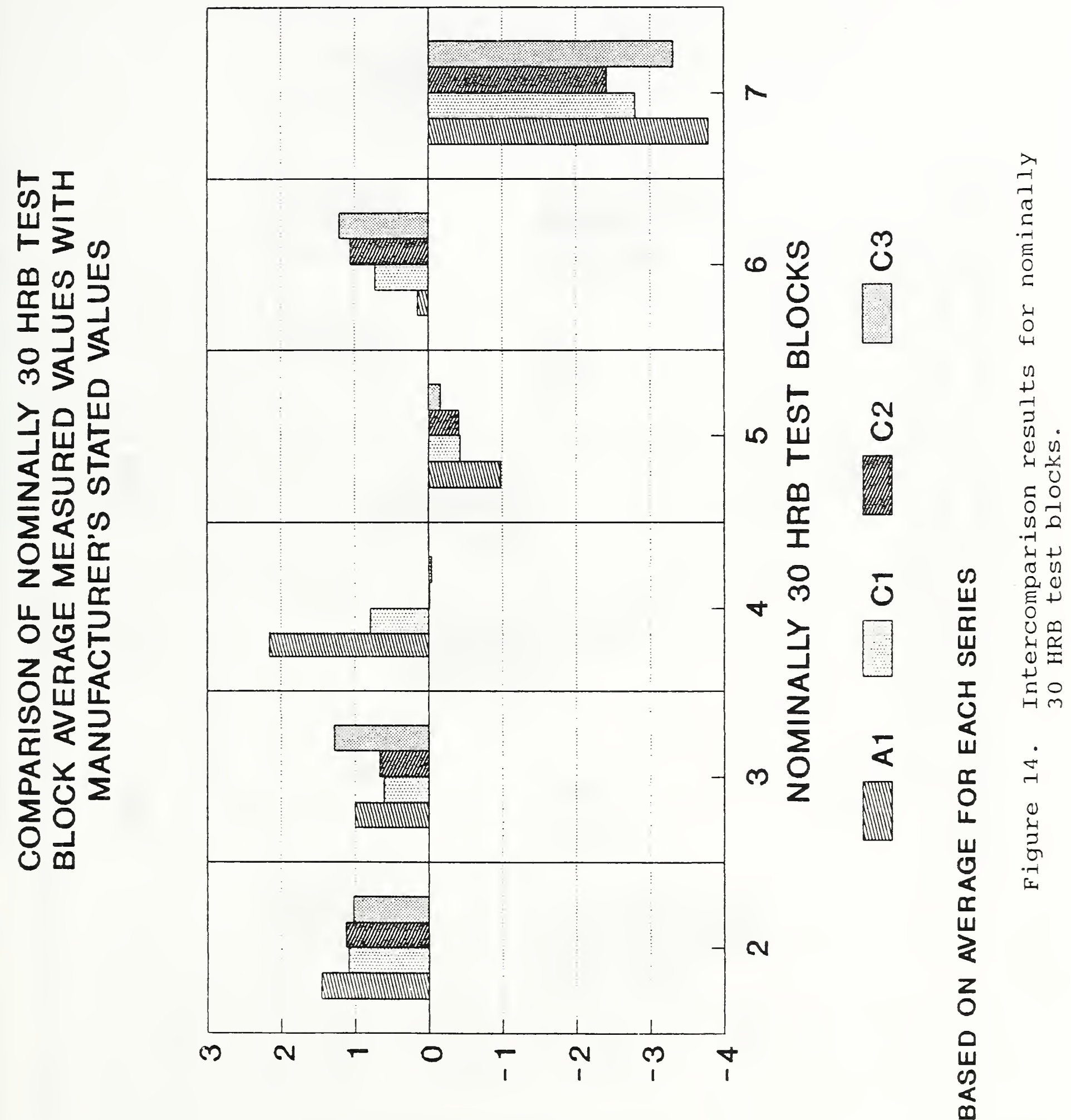

エッா つZートの 

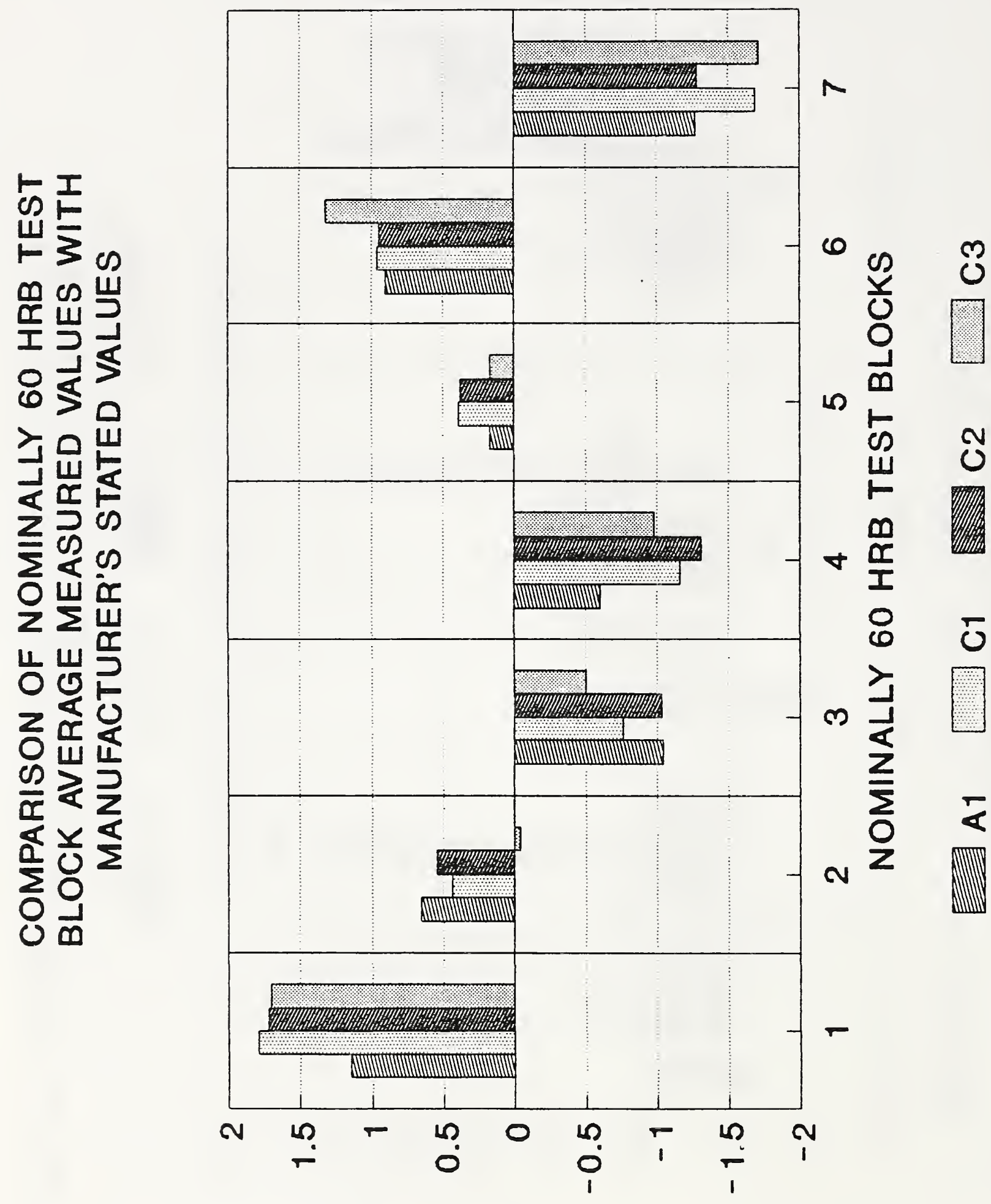

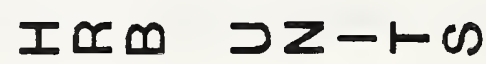



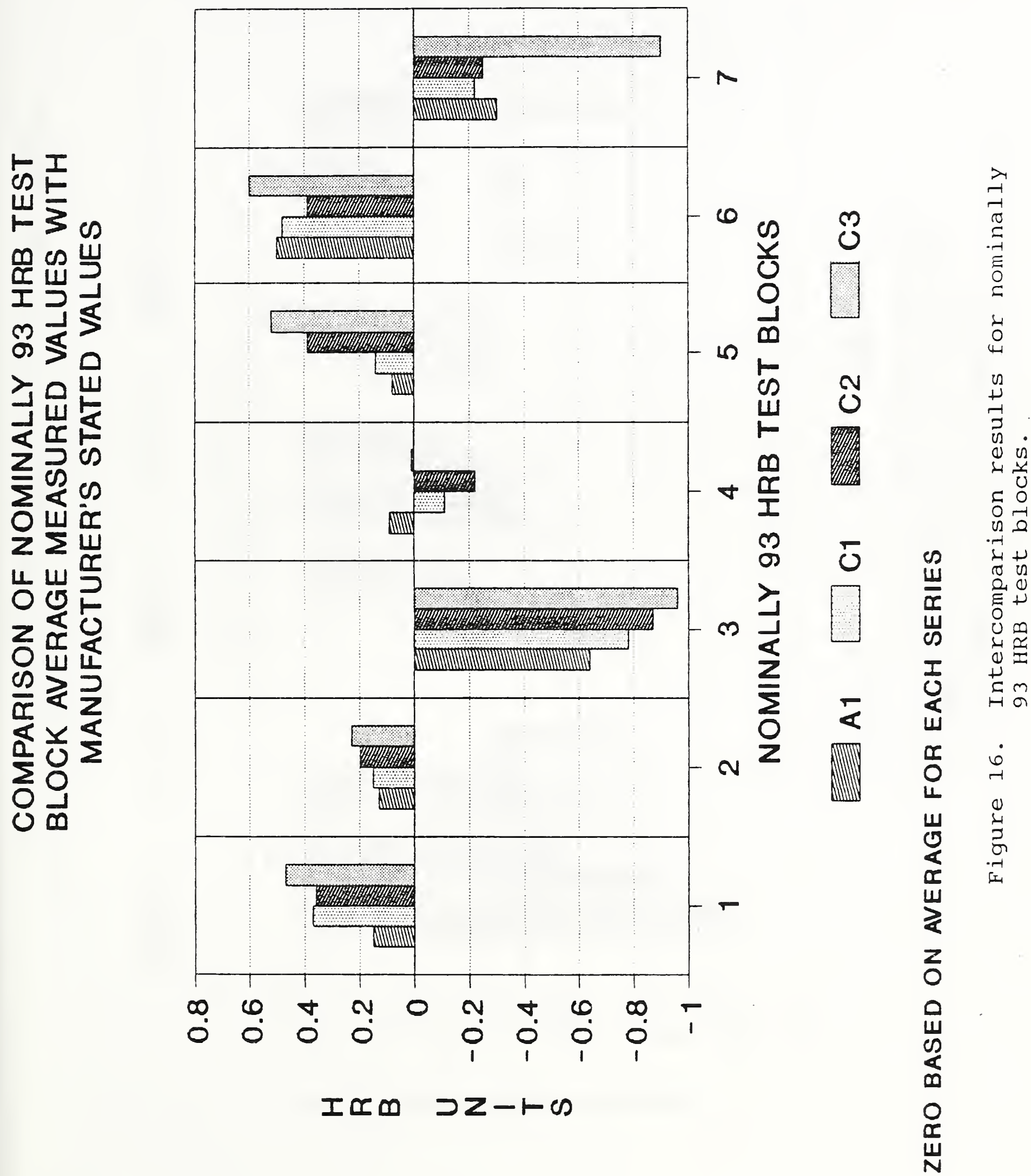


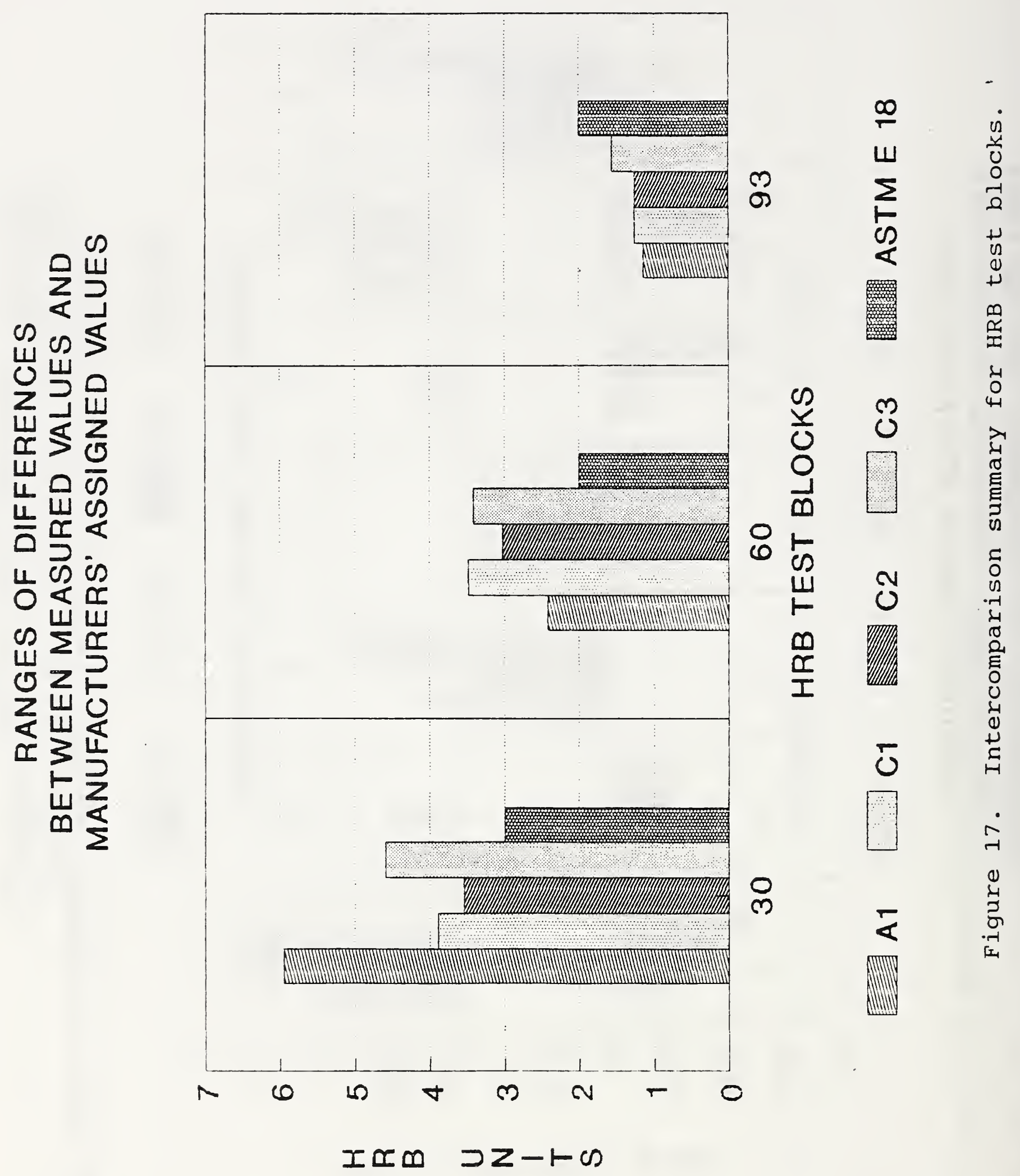



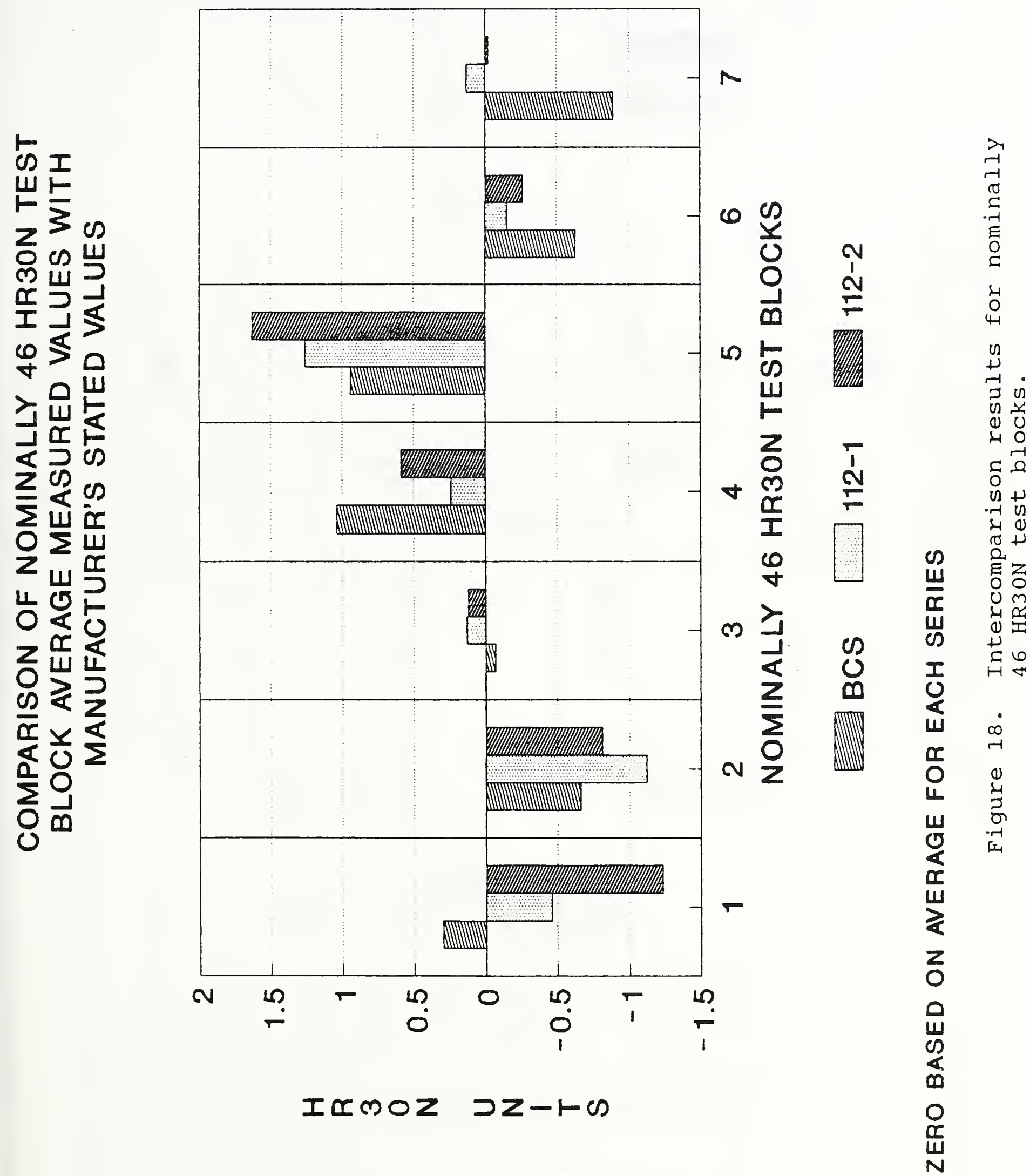

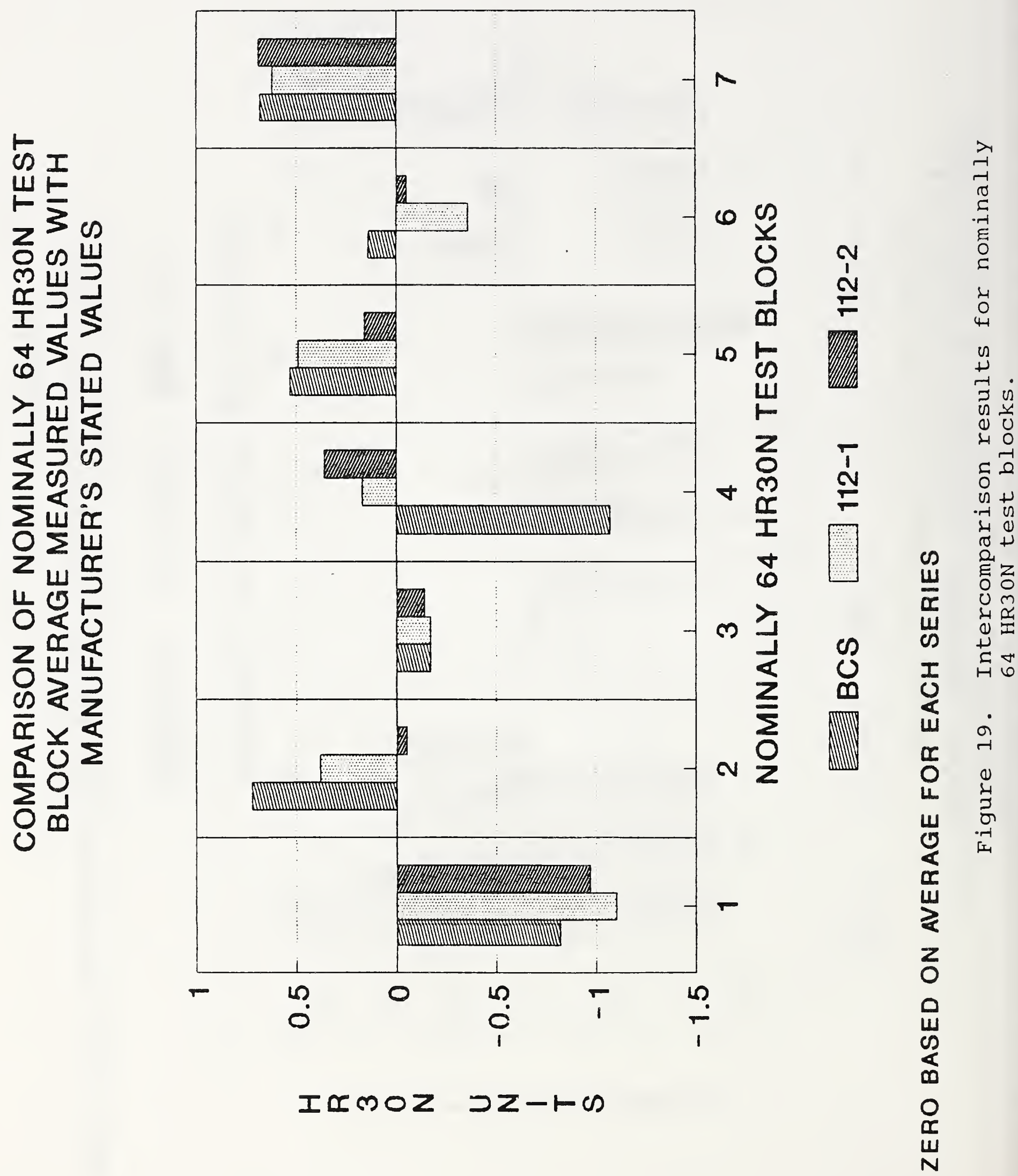

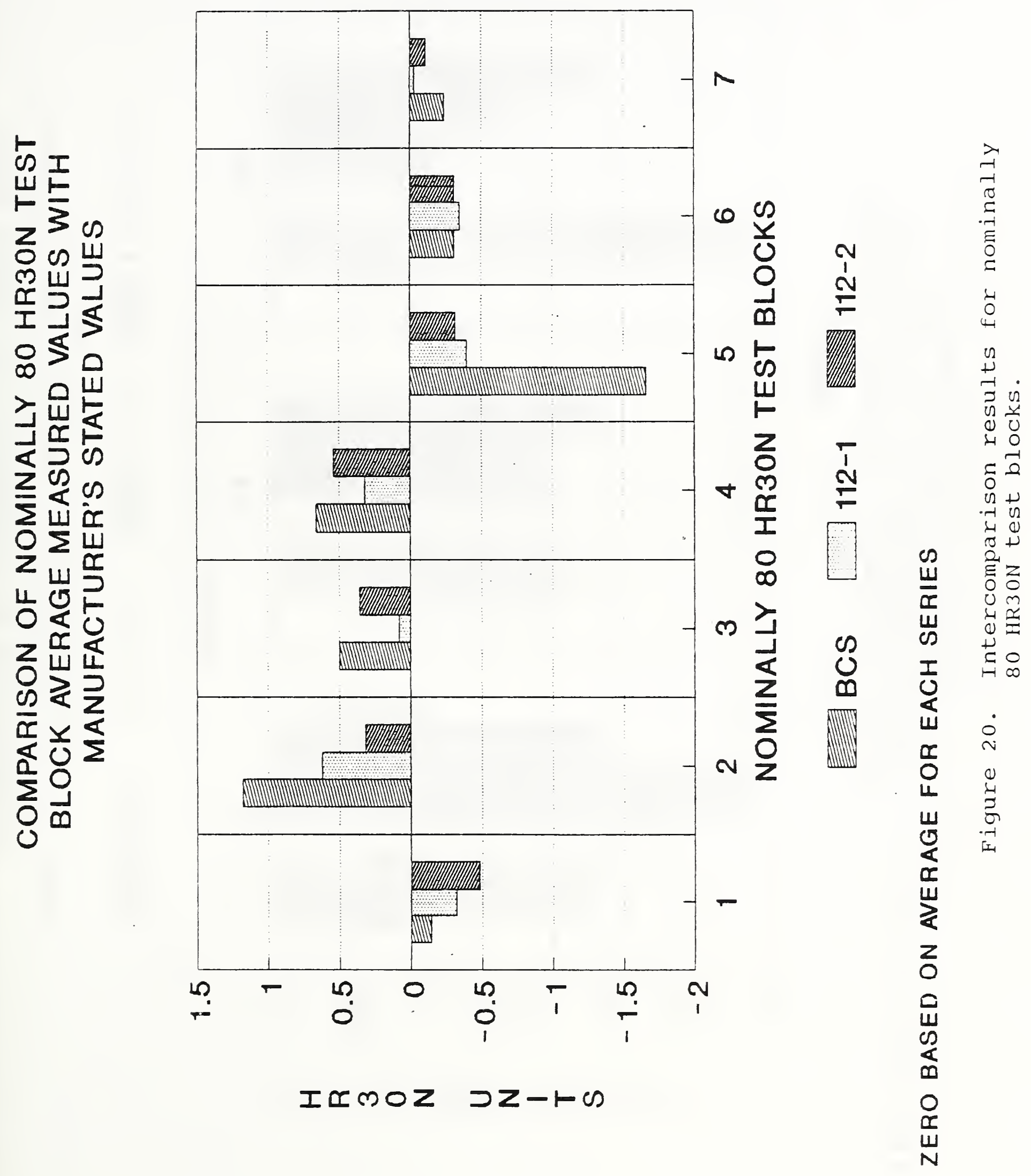

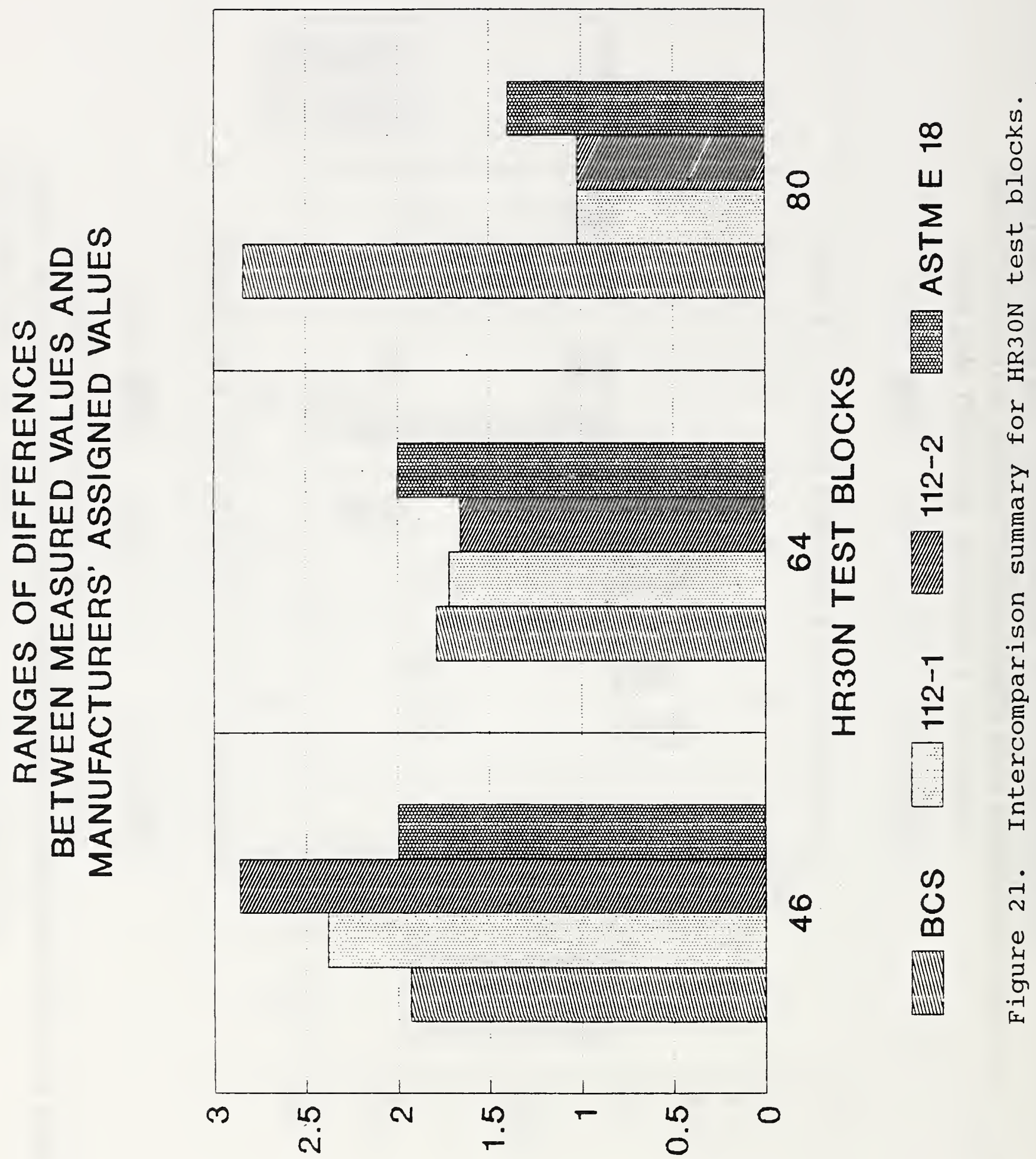

エエMOZ つZートル 


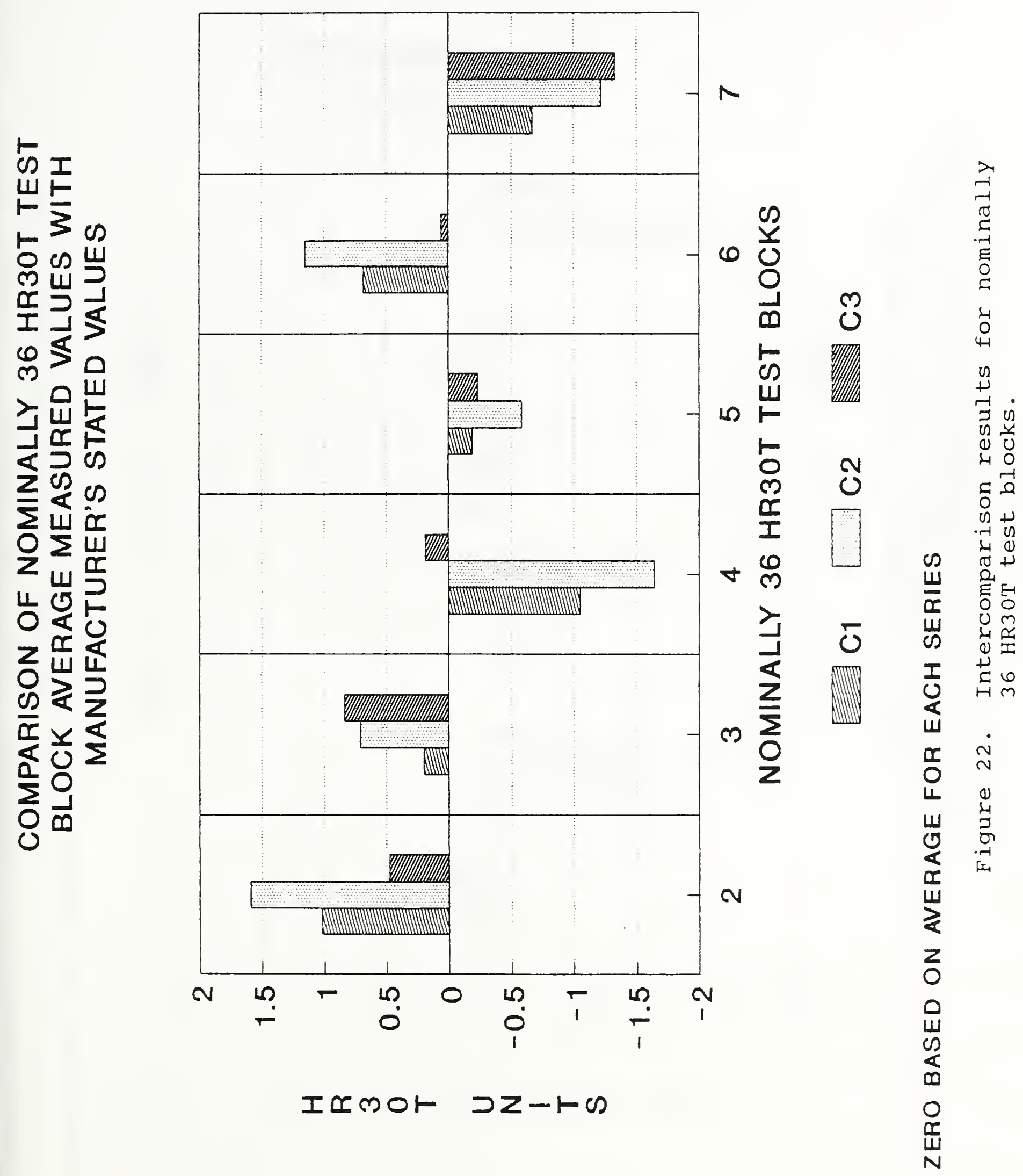



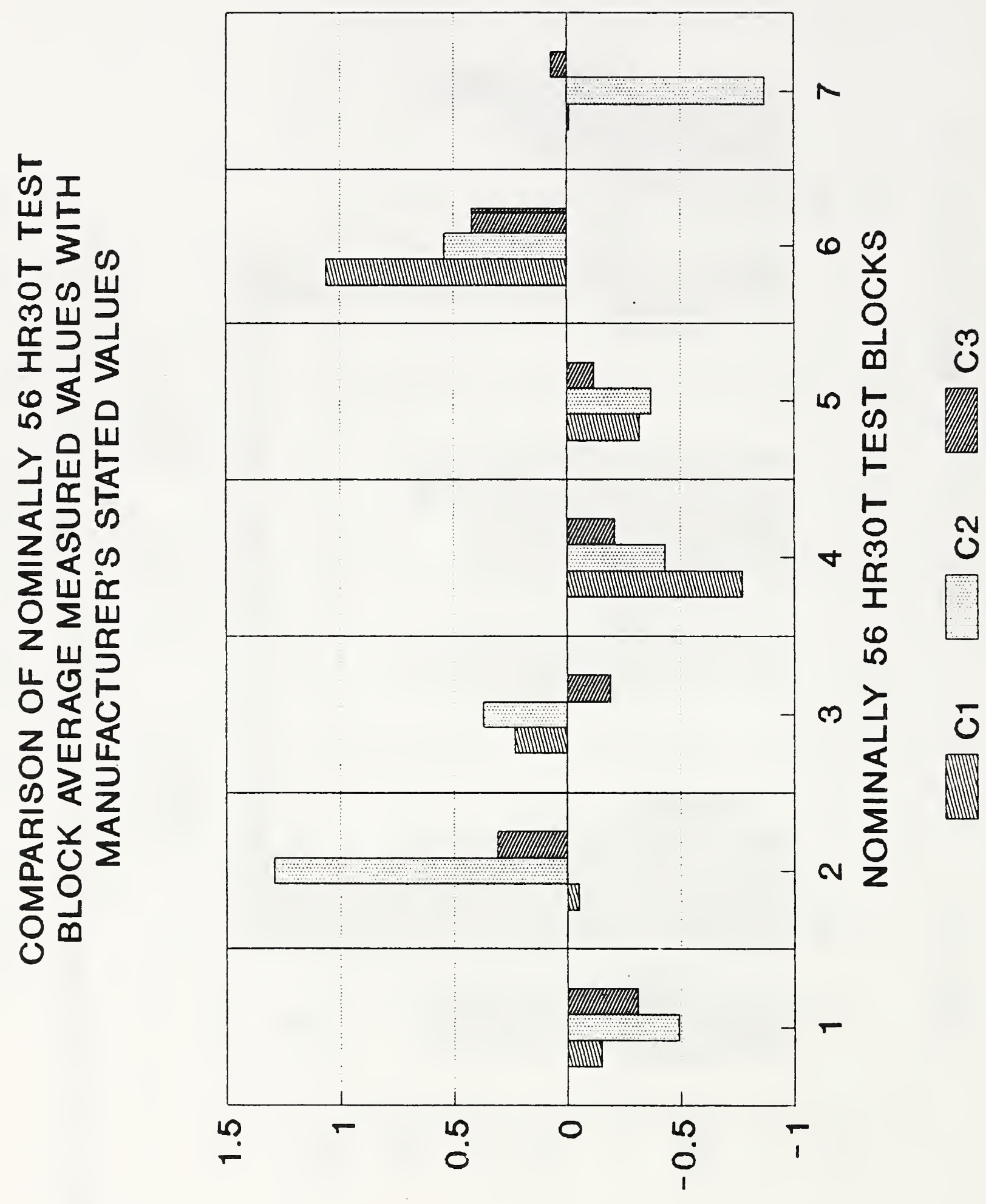

エッッ⿻上 つZートの 


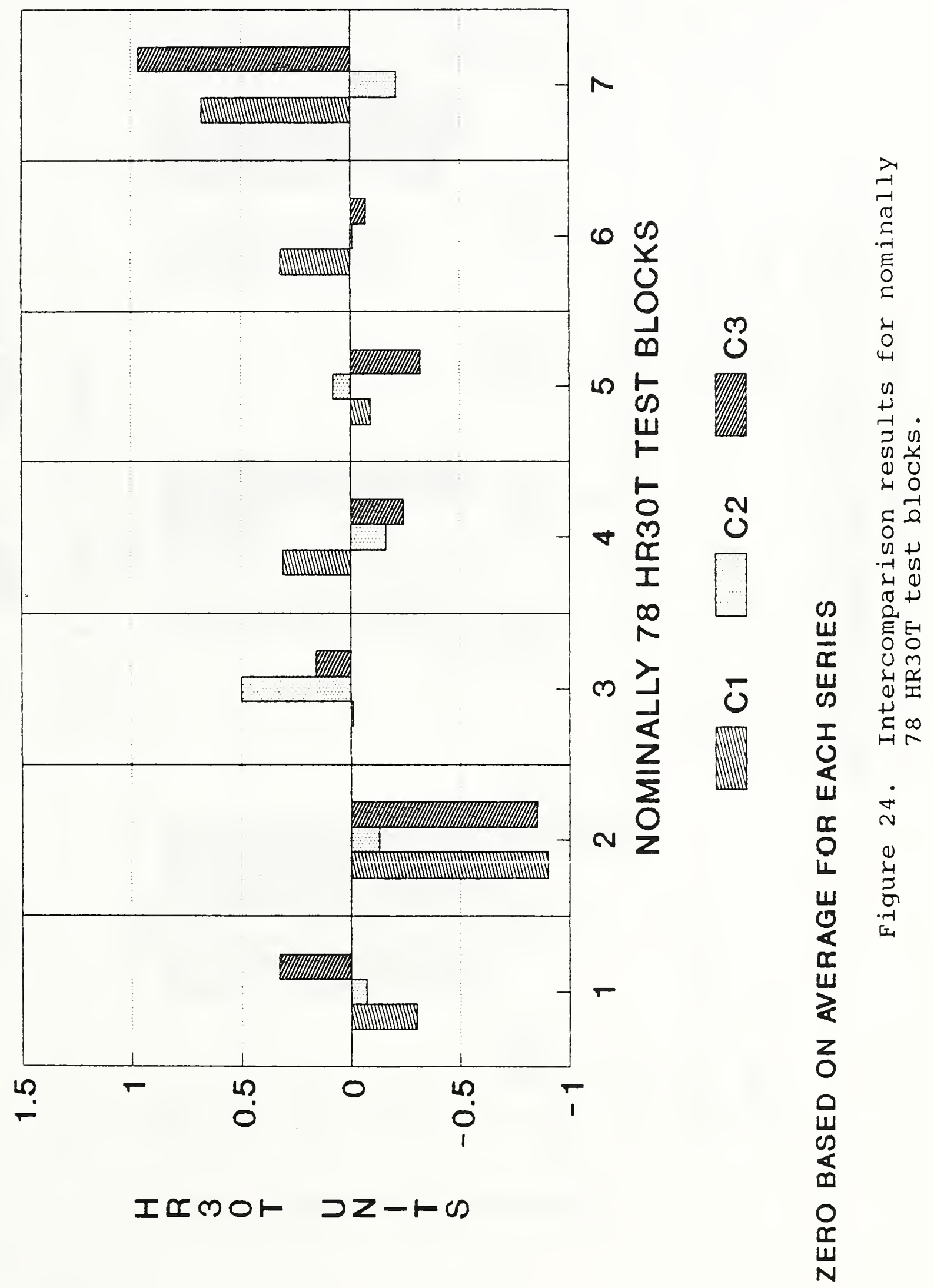




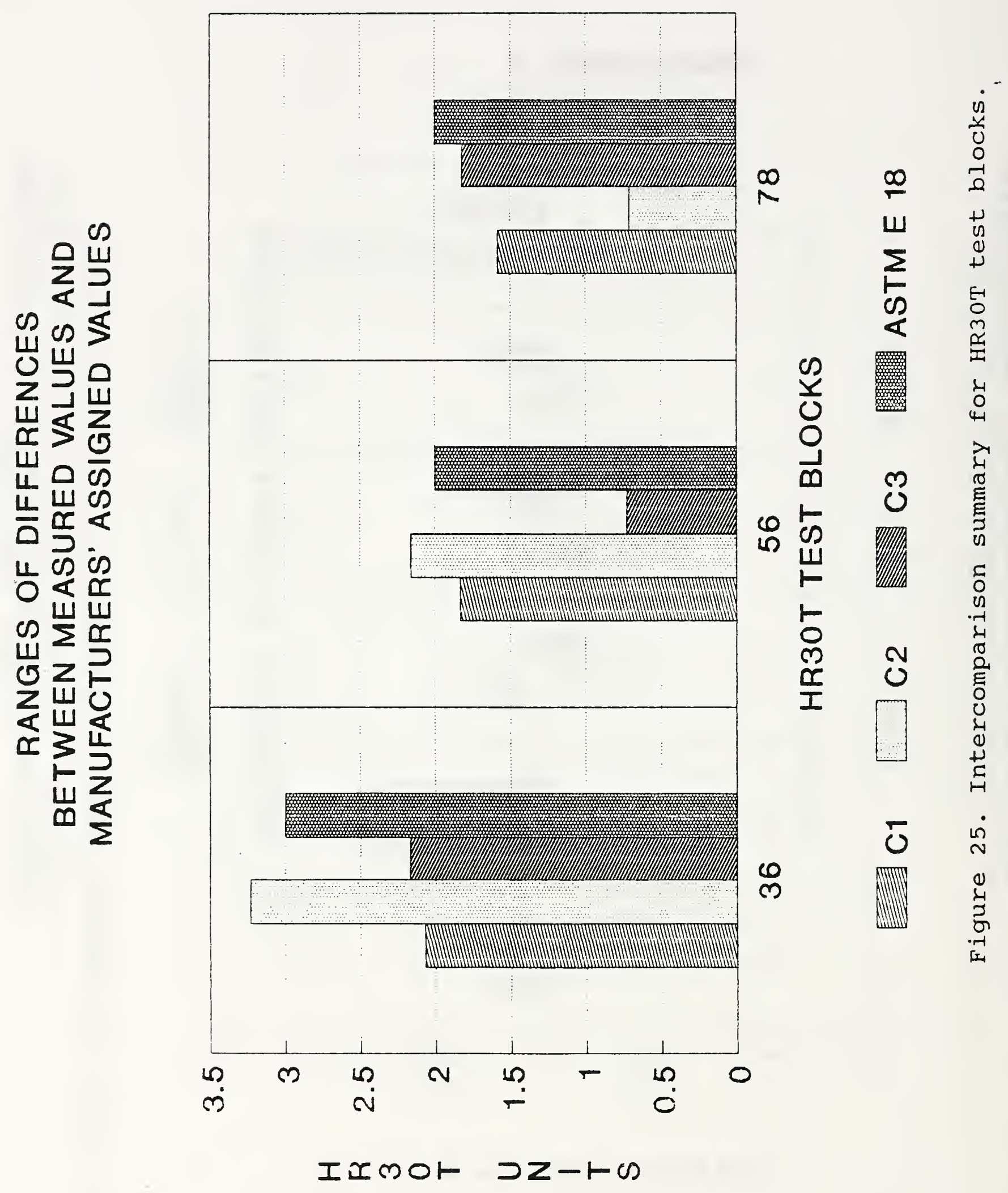




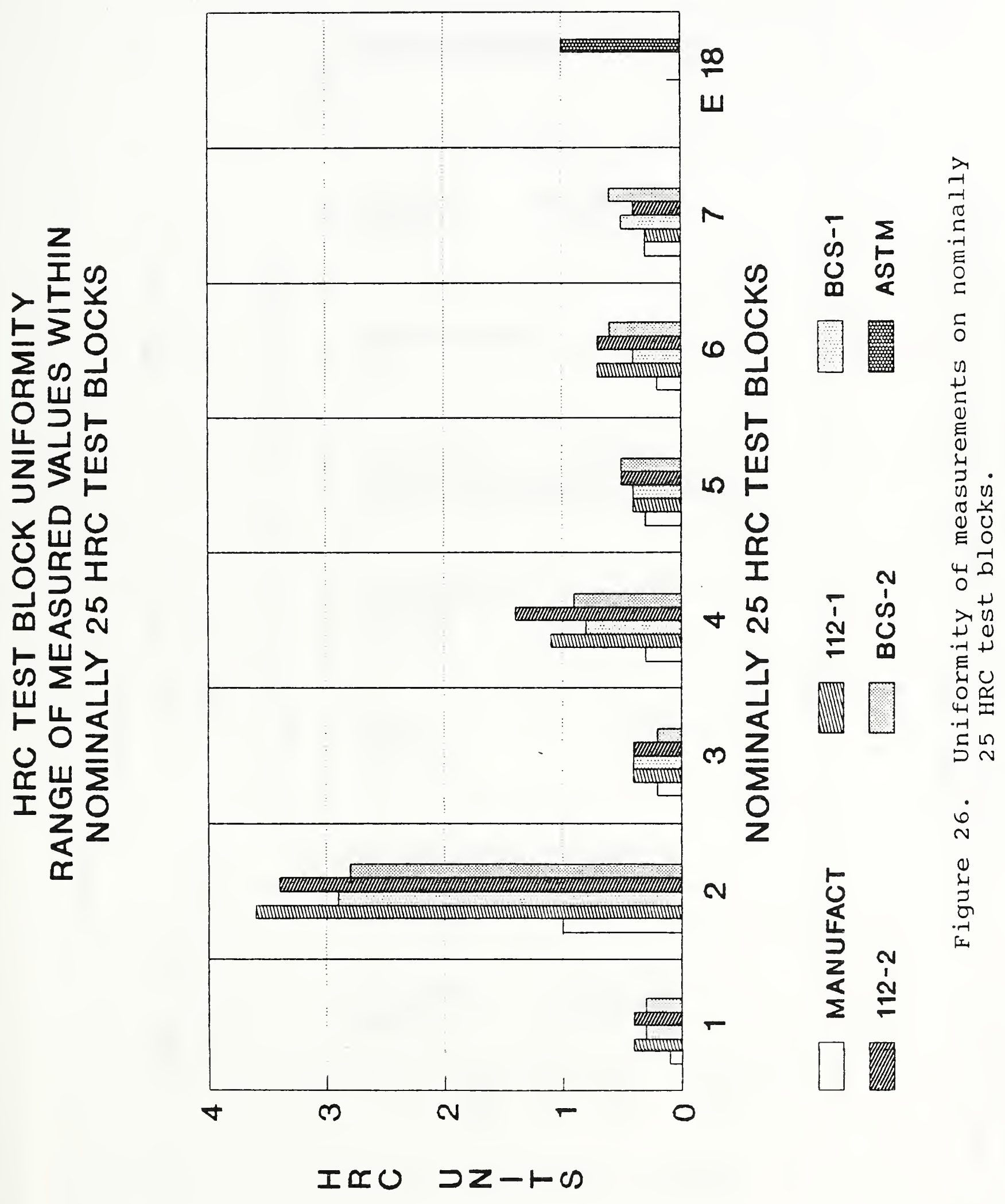




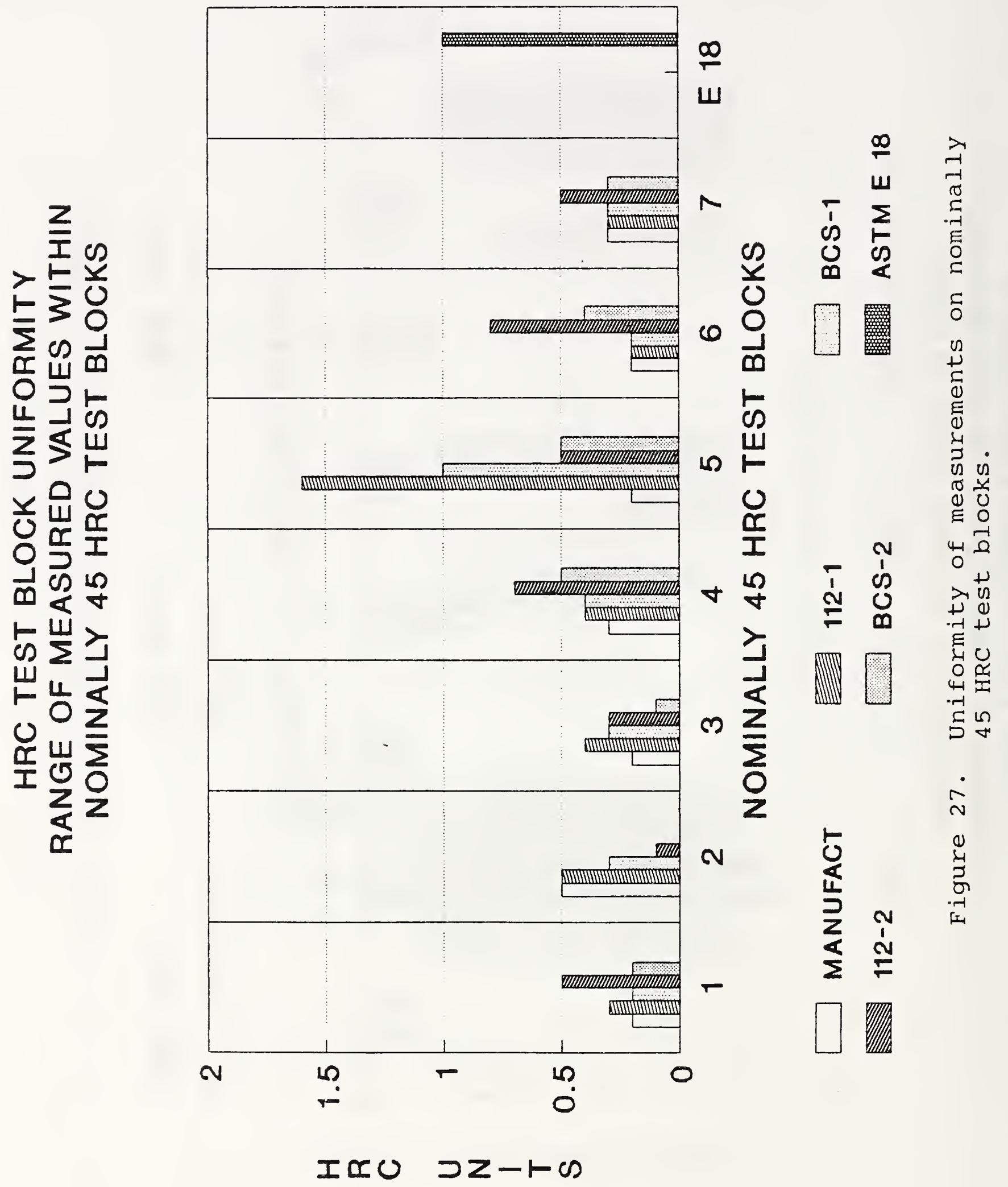



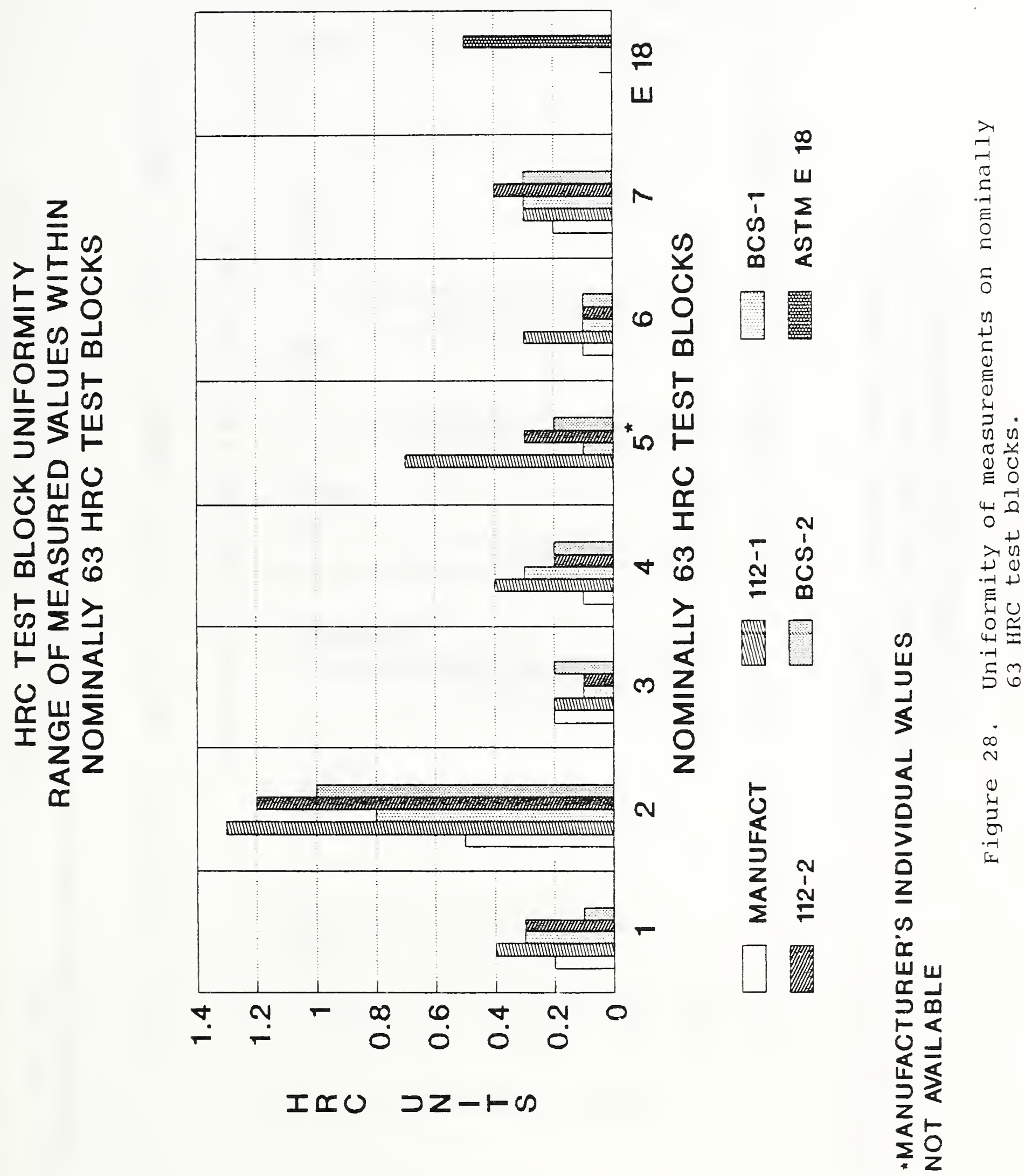

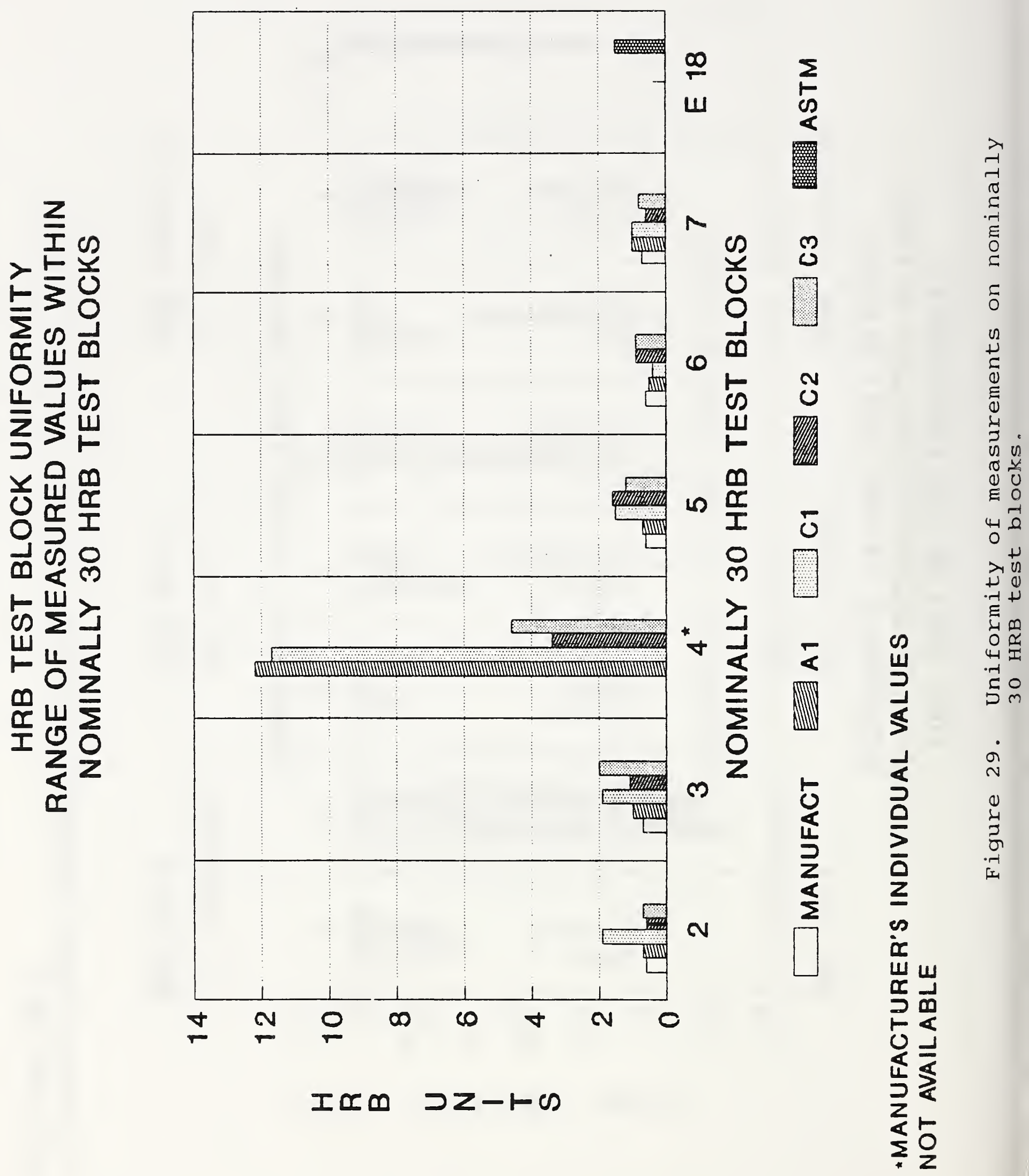


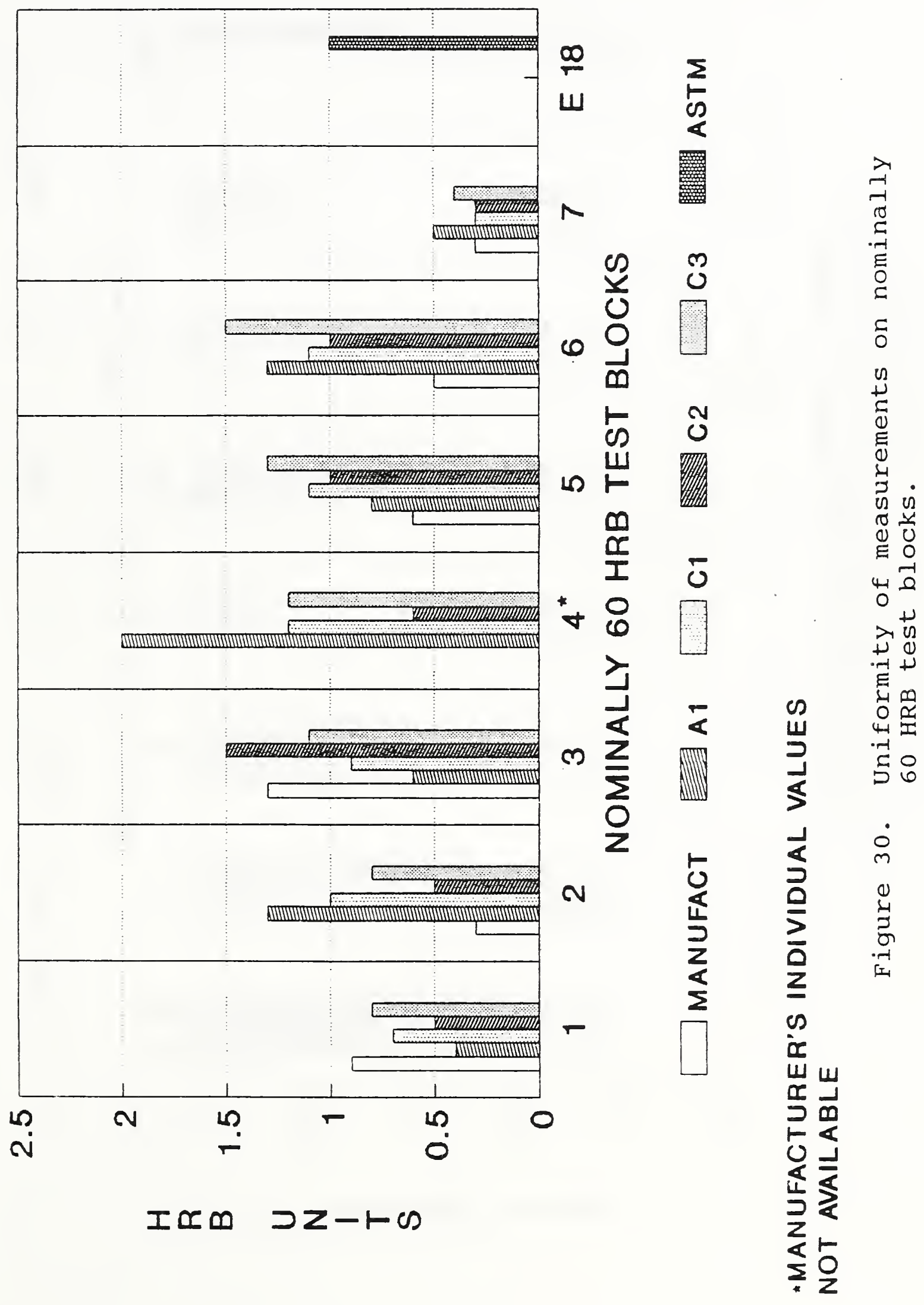



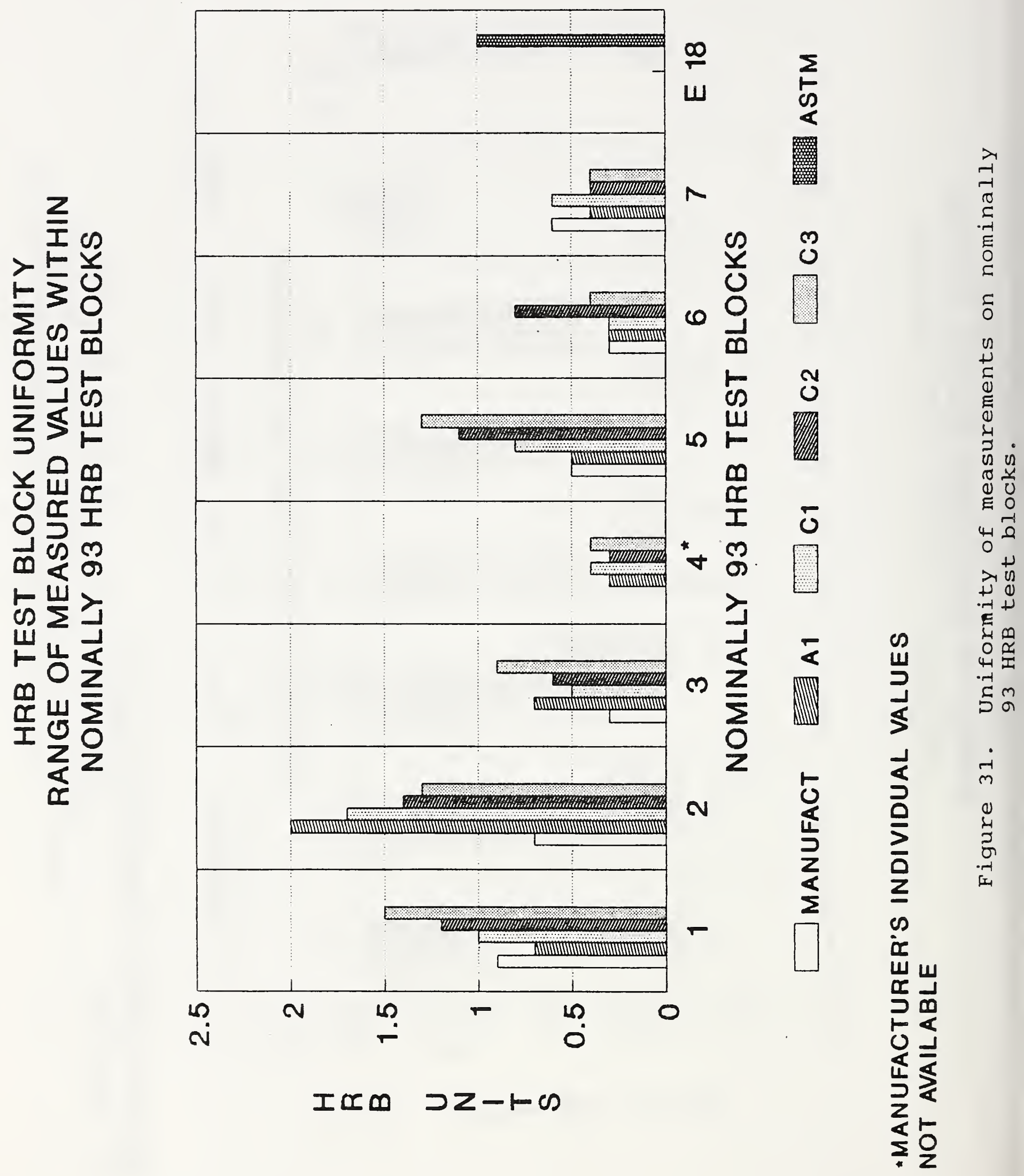


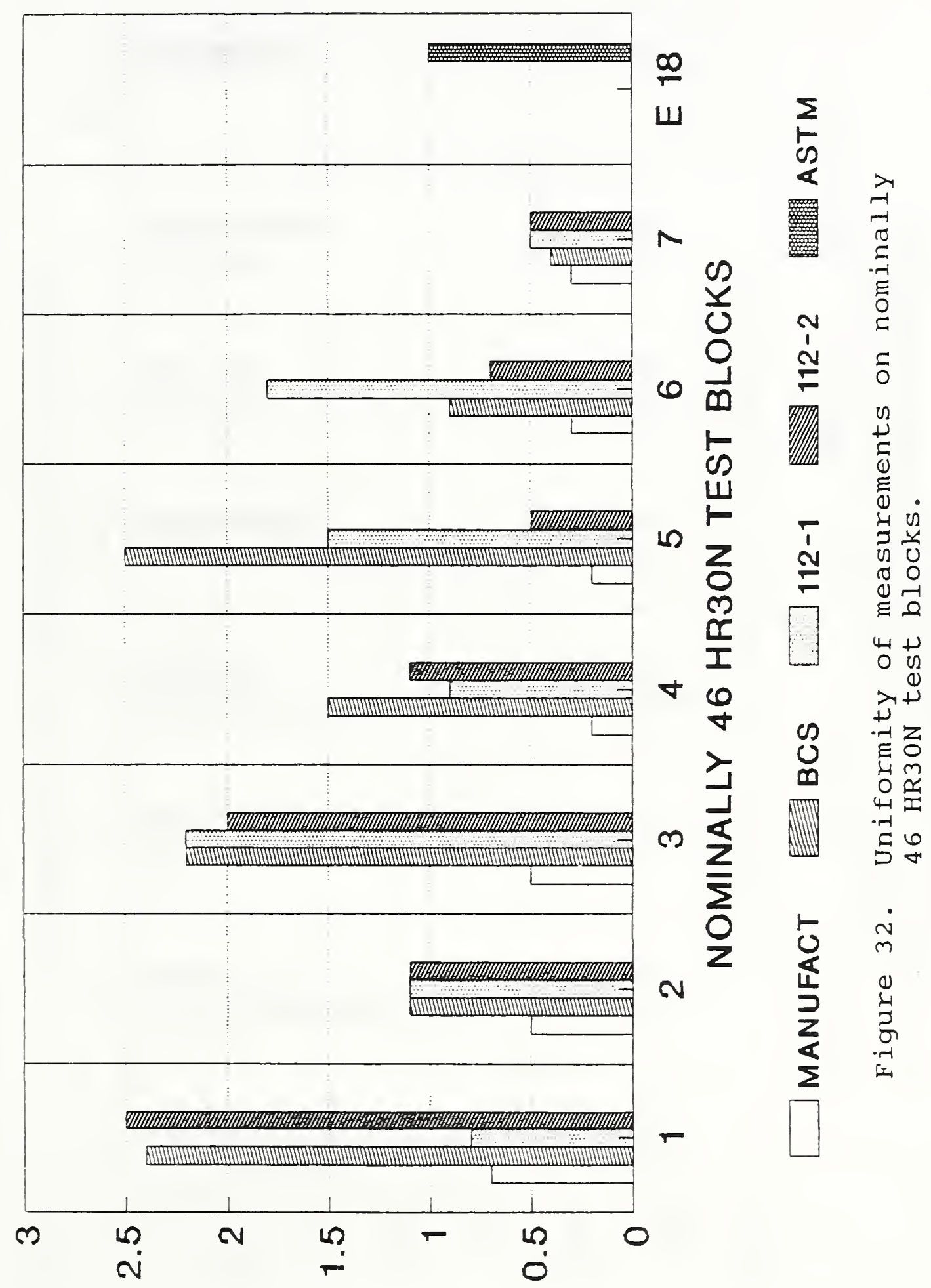

IோOZ गZートऍ 

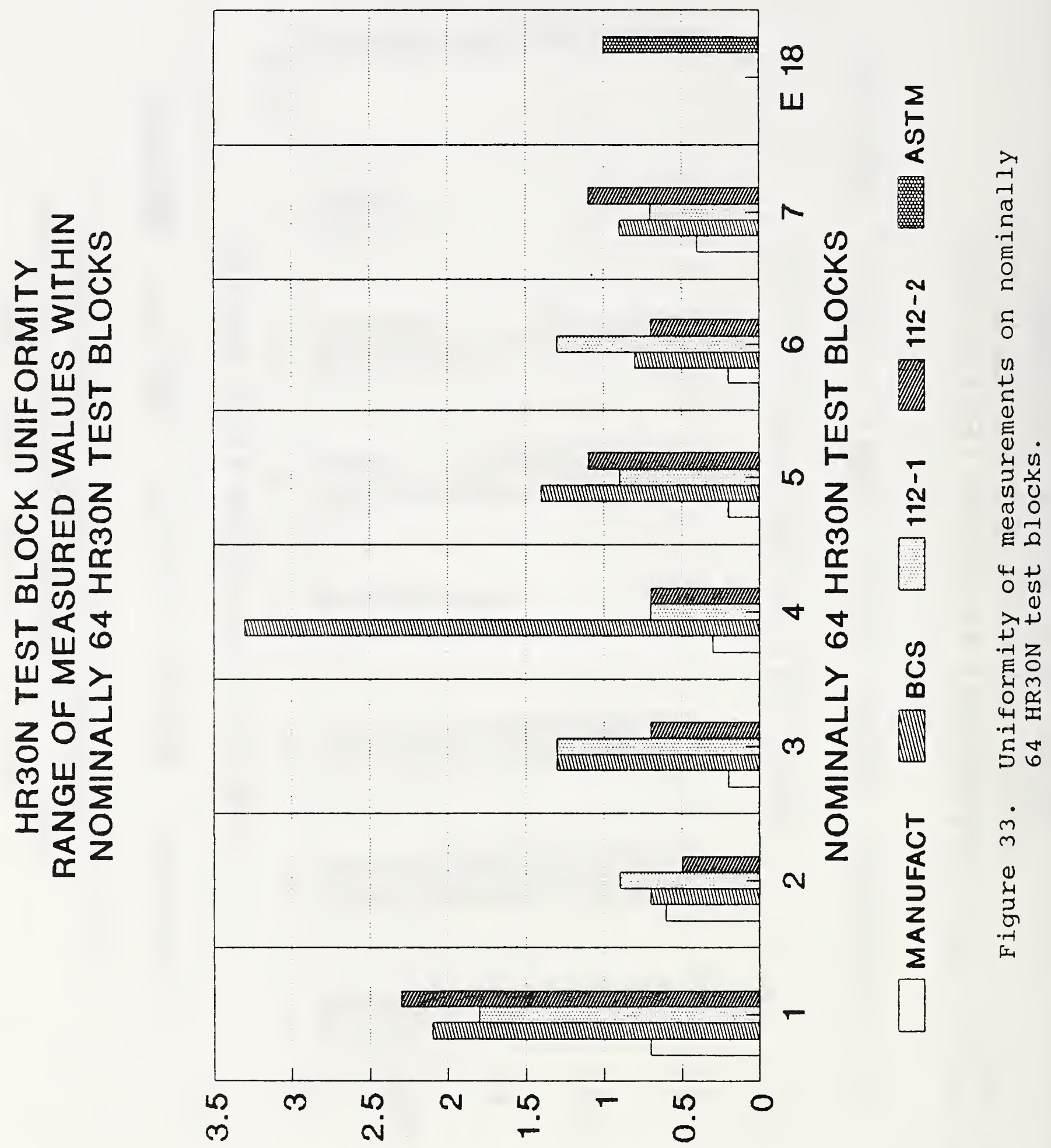

エロッ○Z गZートの 


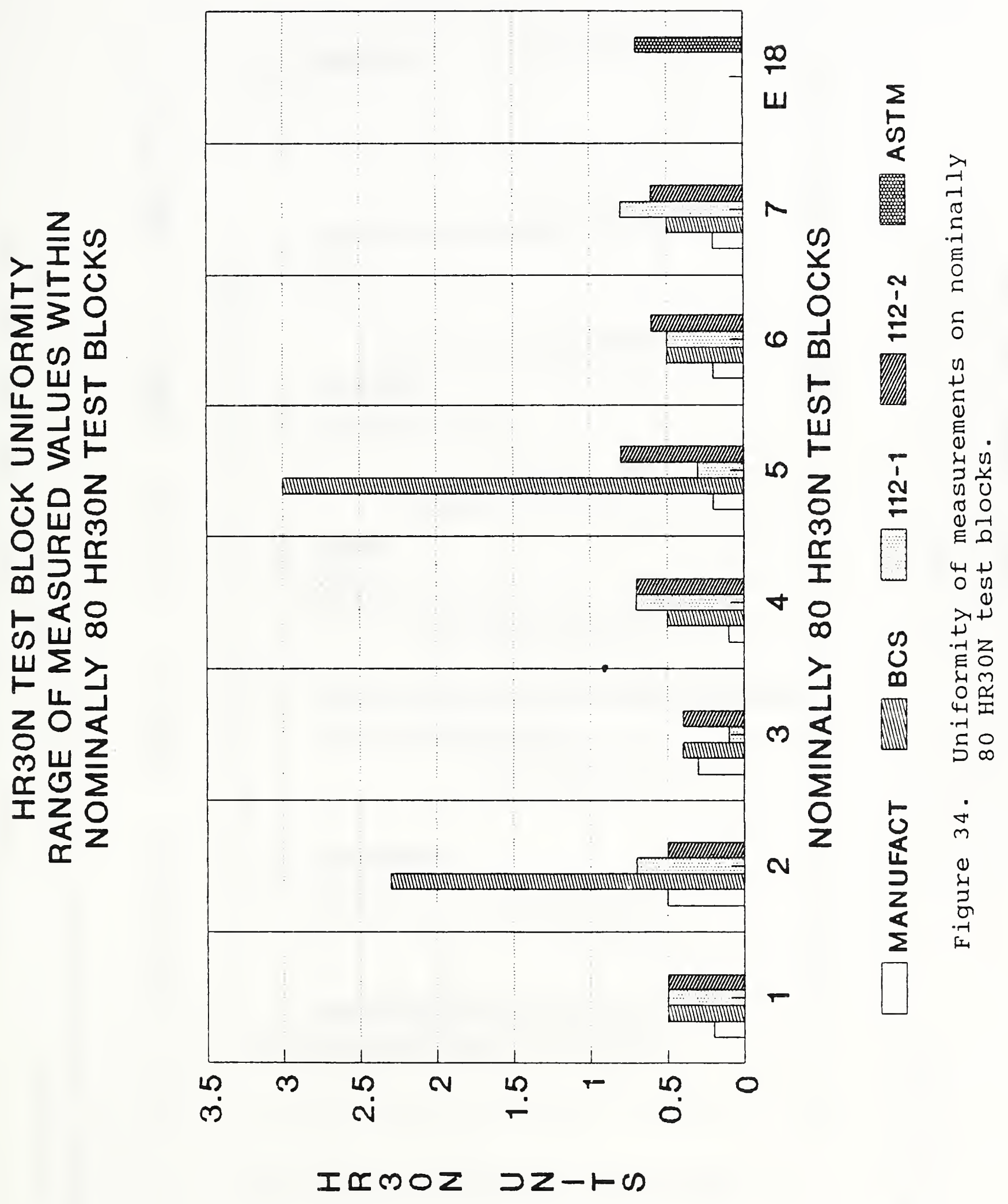




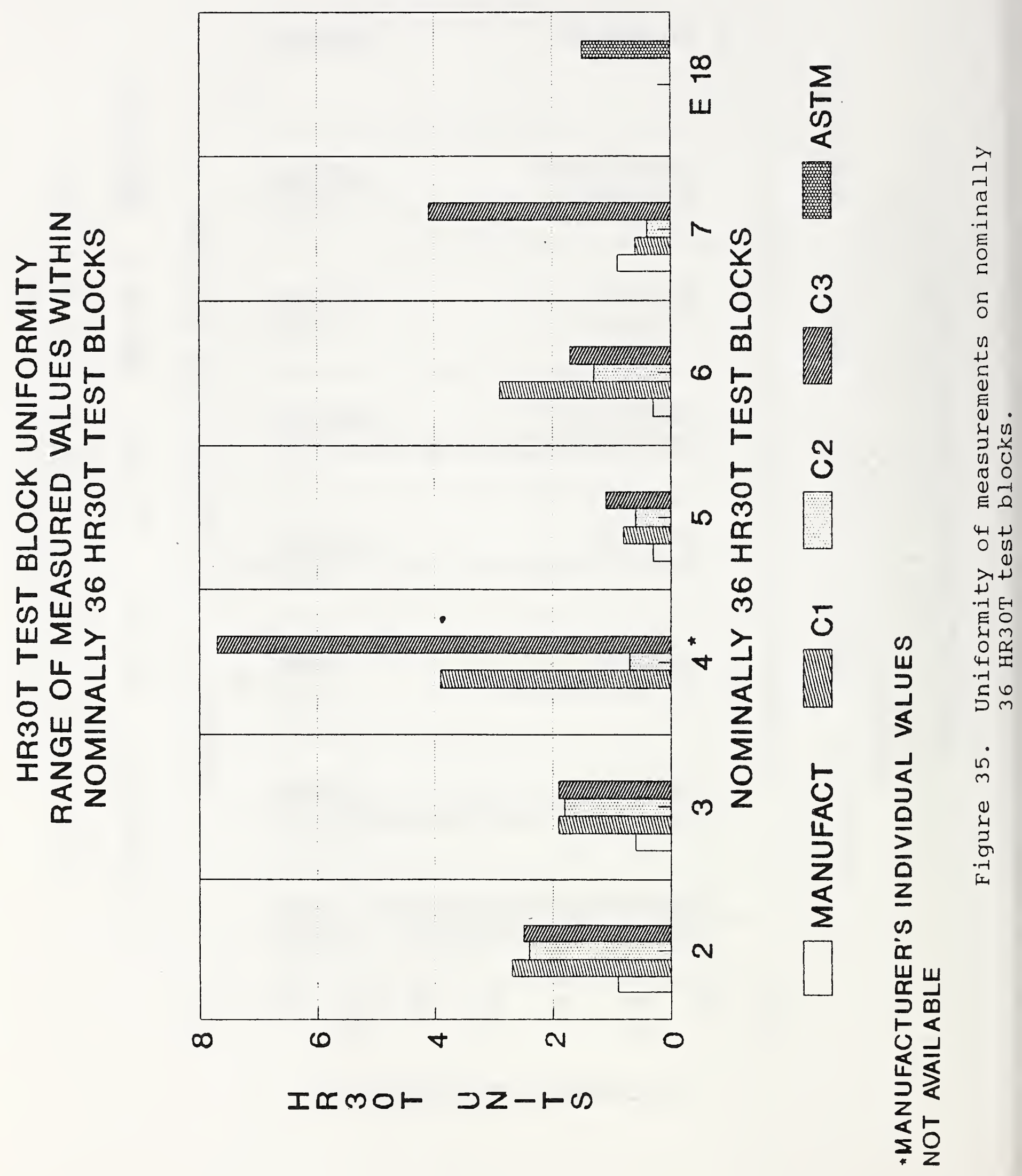




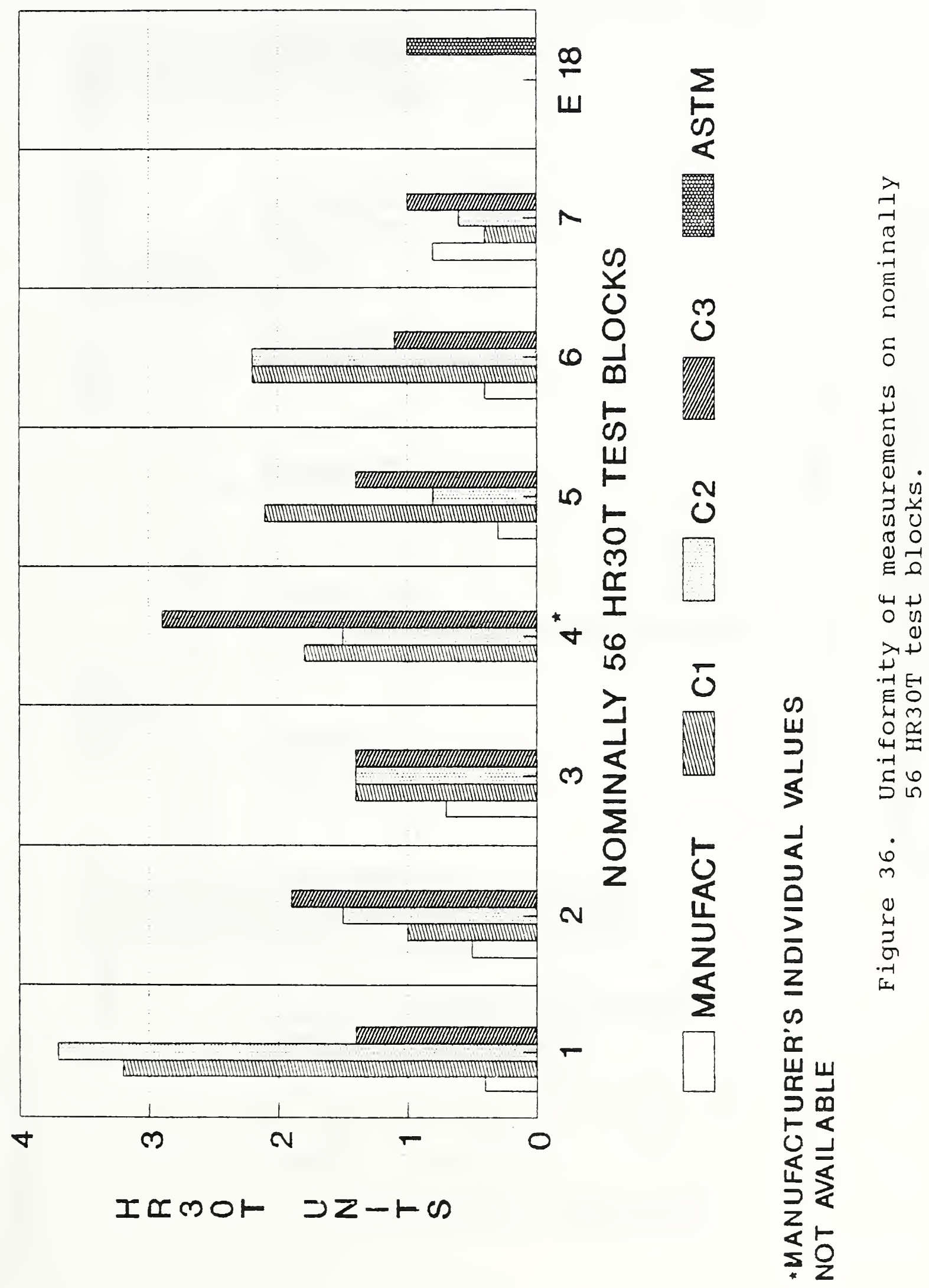



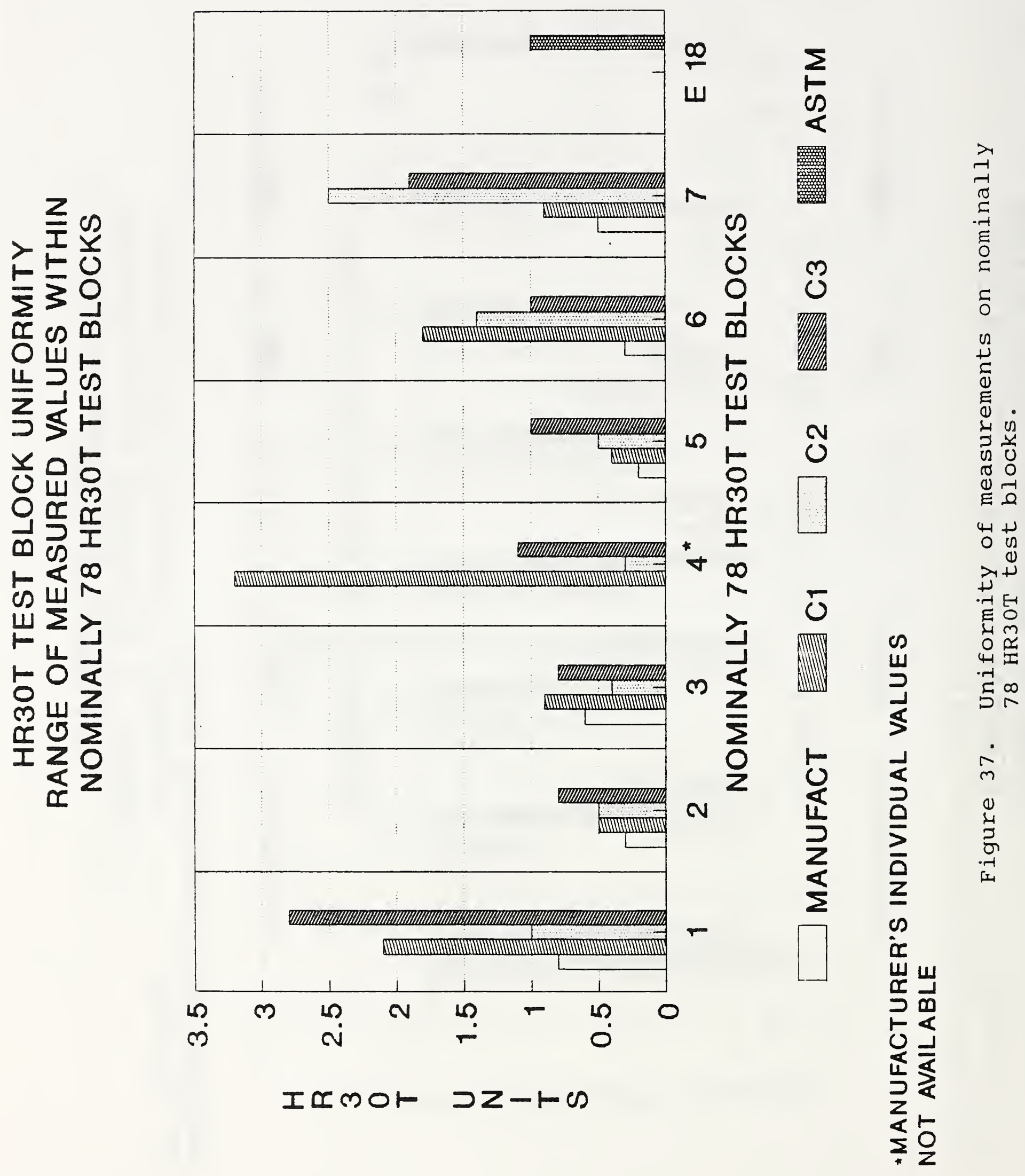


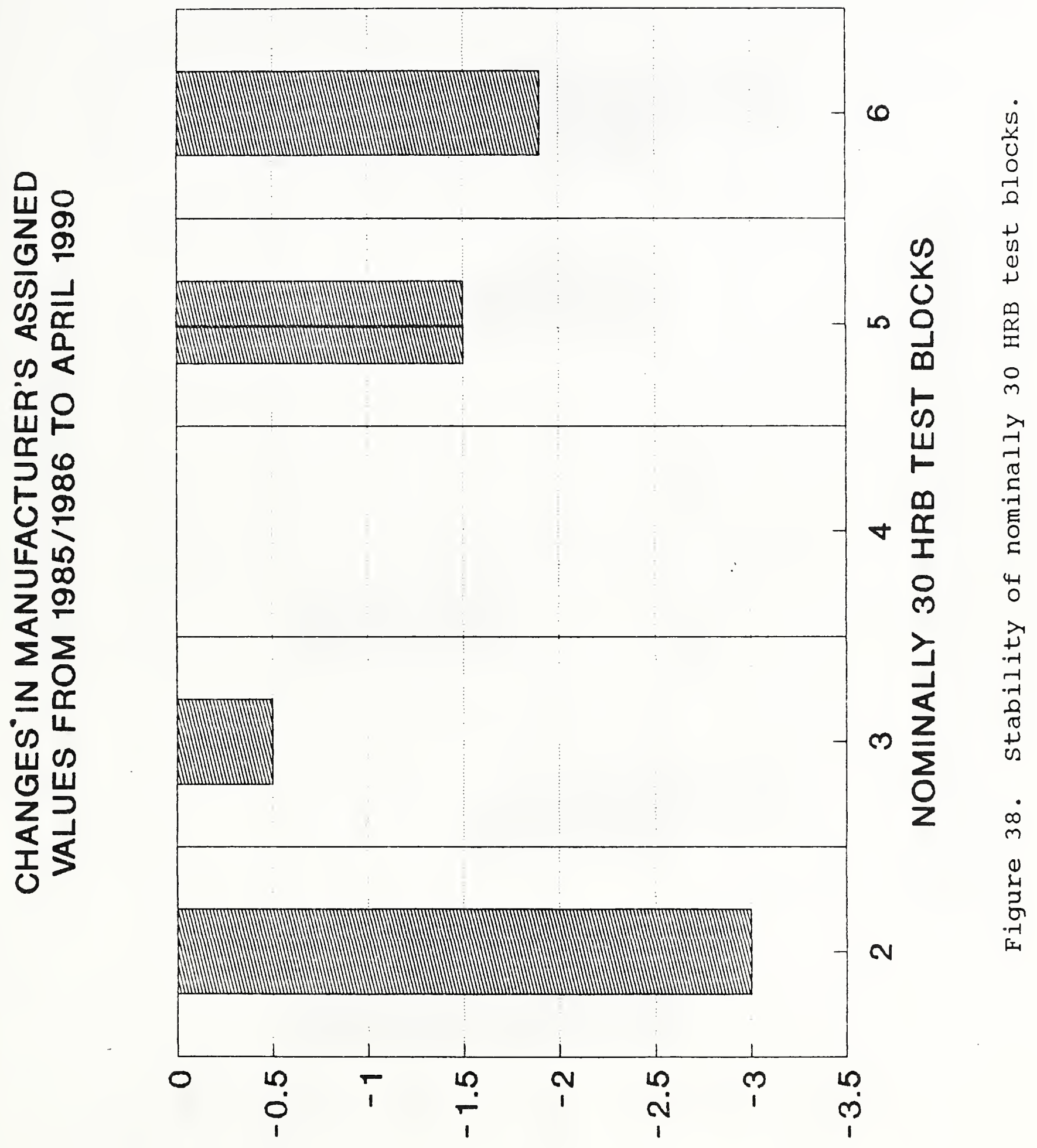

IロM つZートル 

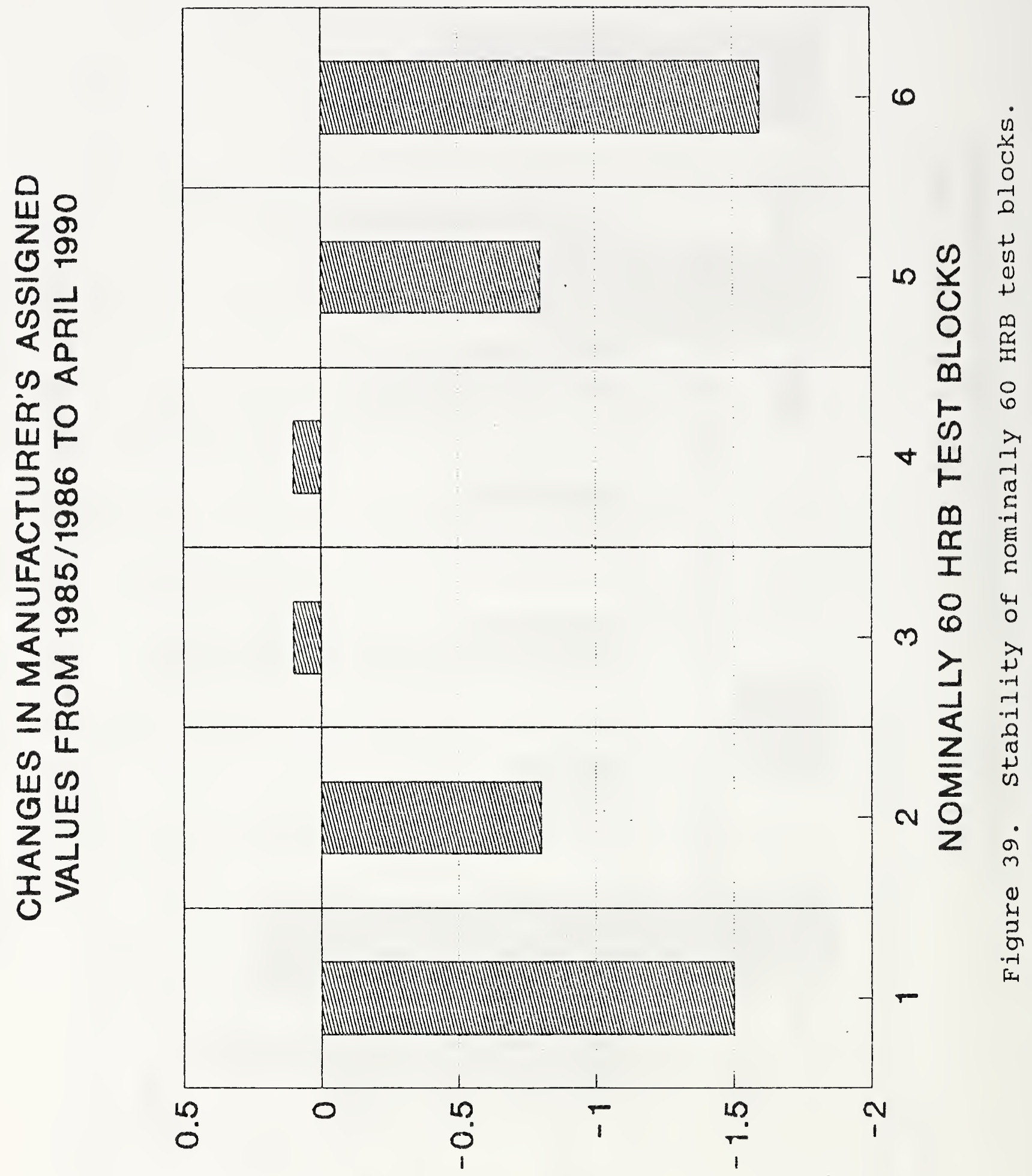

I爪® つZートの 


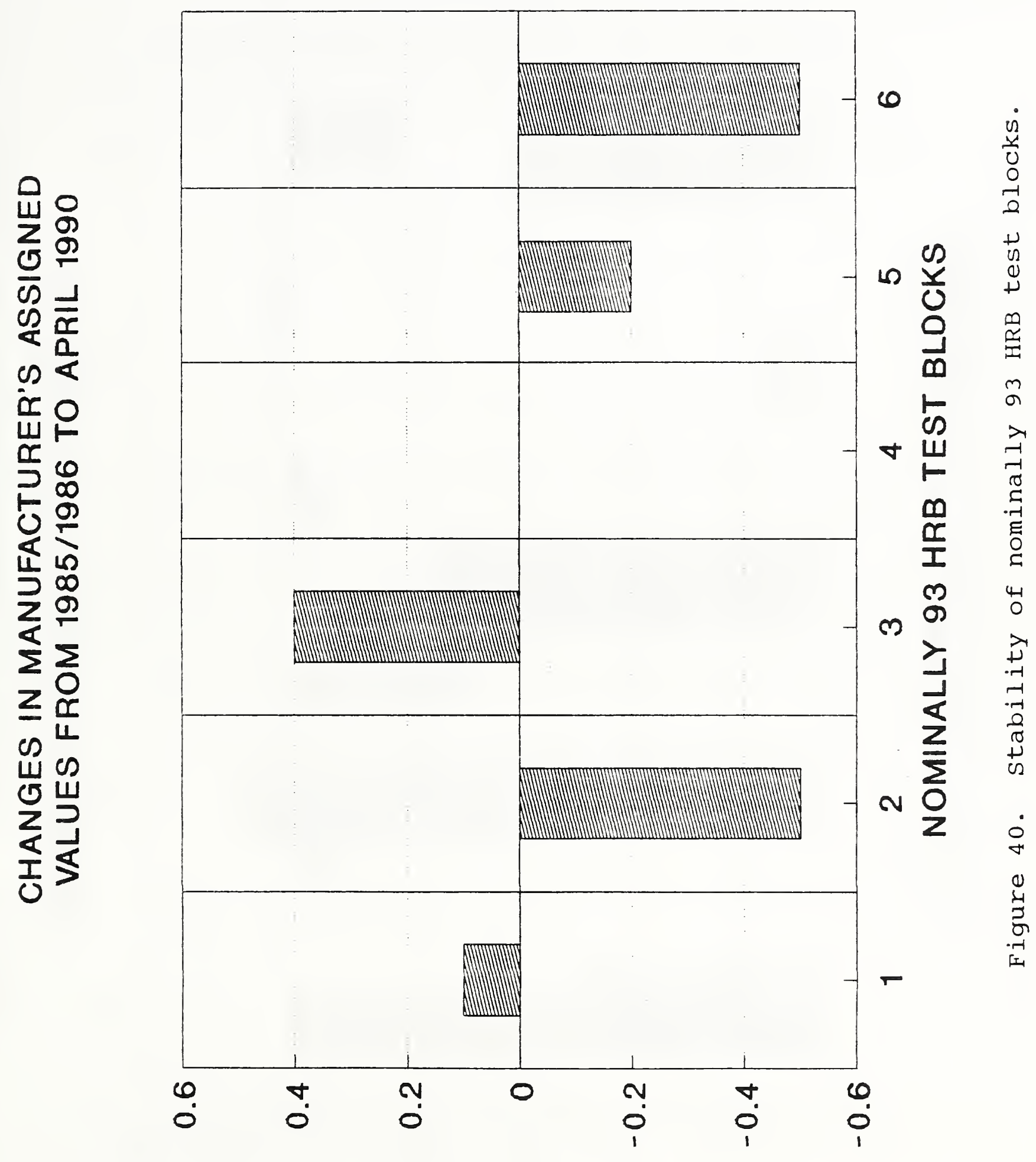

エェm つZートゥ 

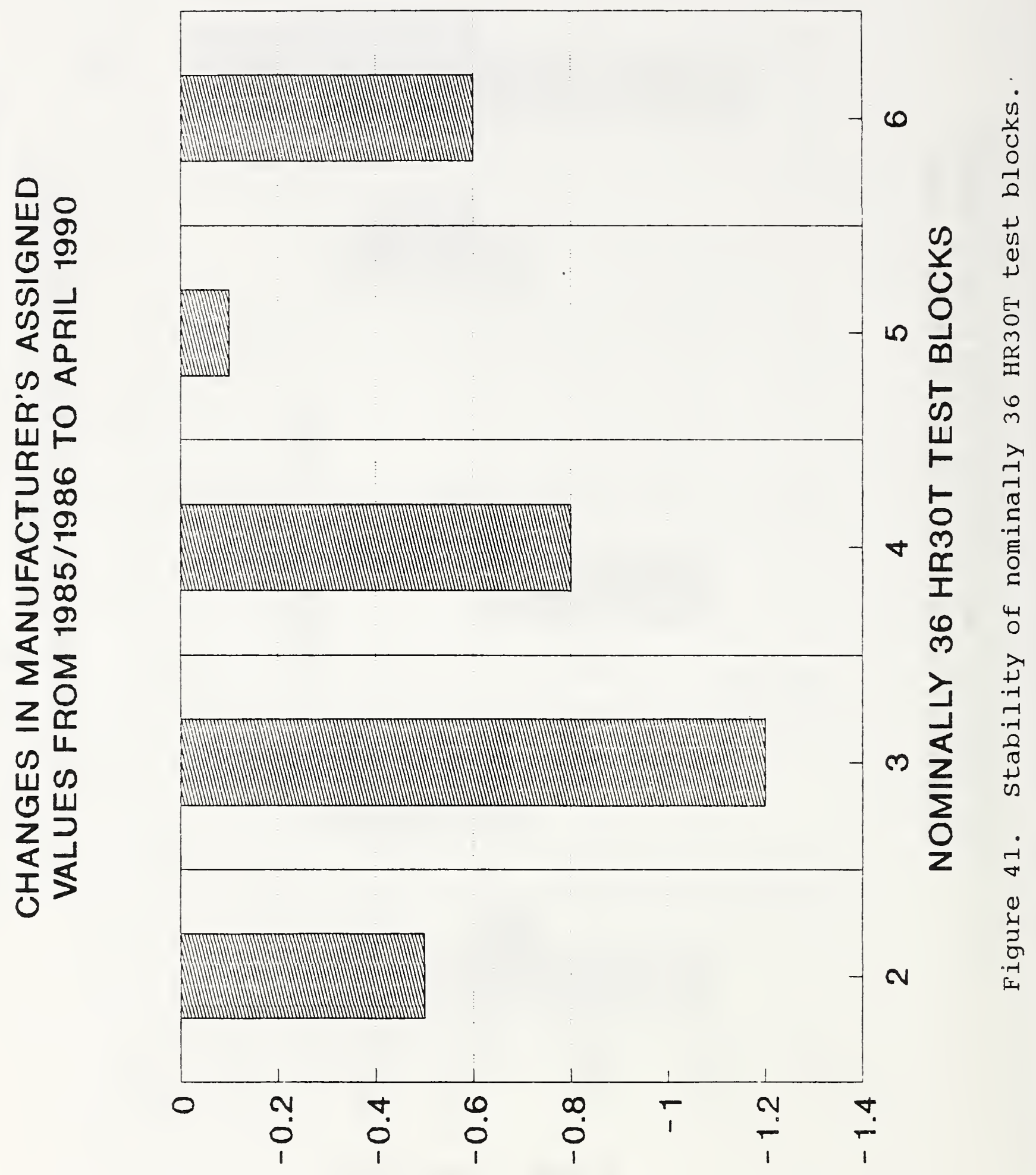

エロッOト つZートの 

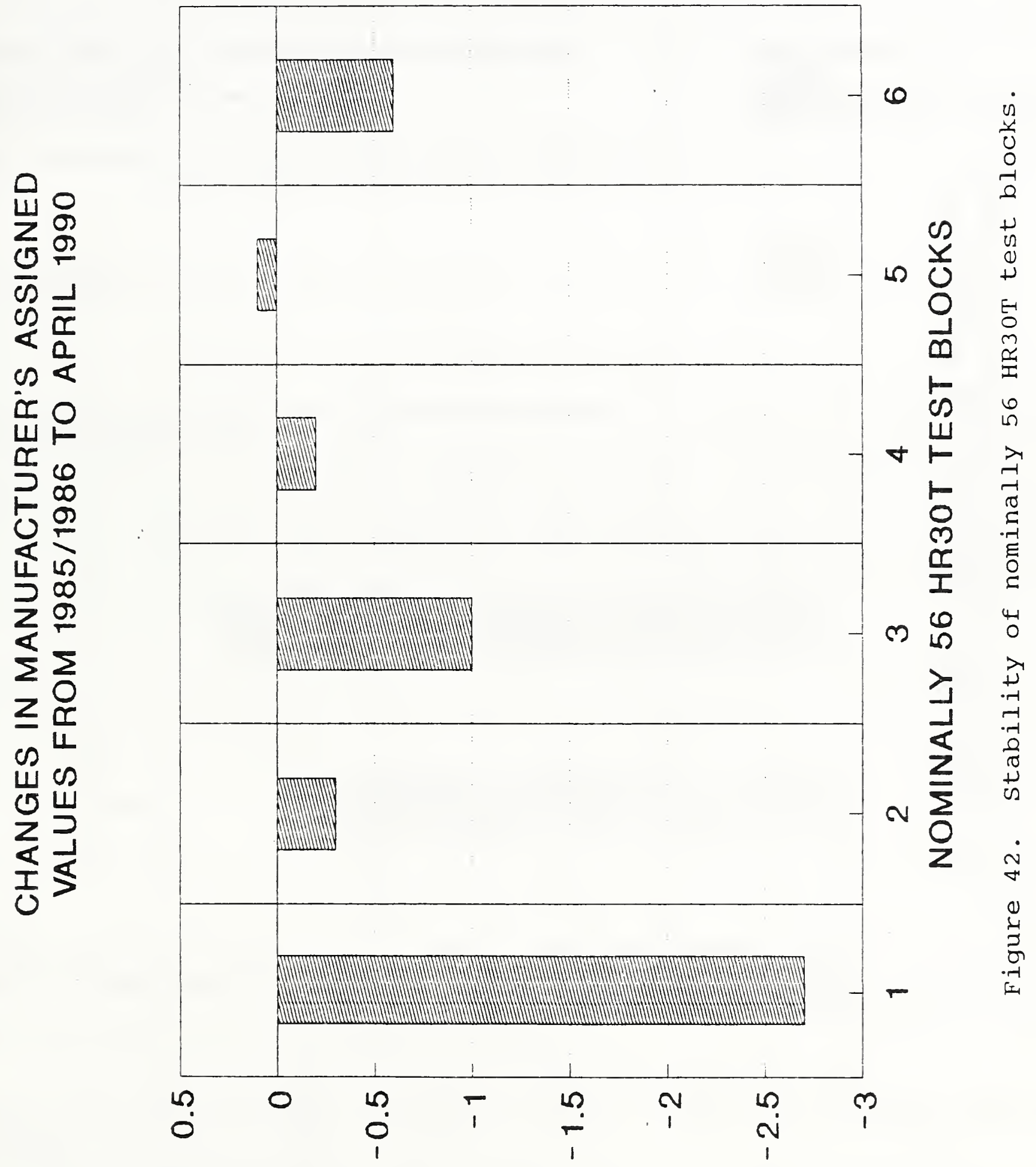

エロッ○ト つZートの 

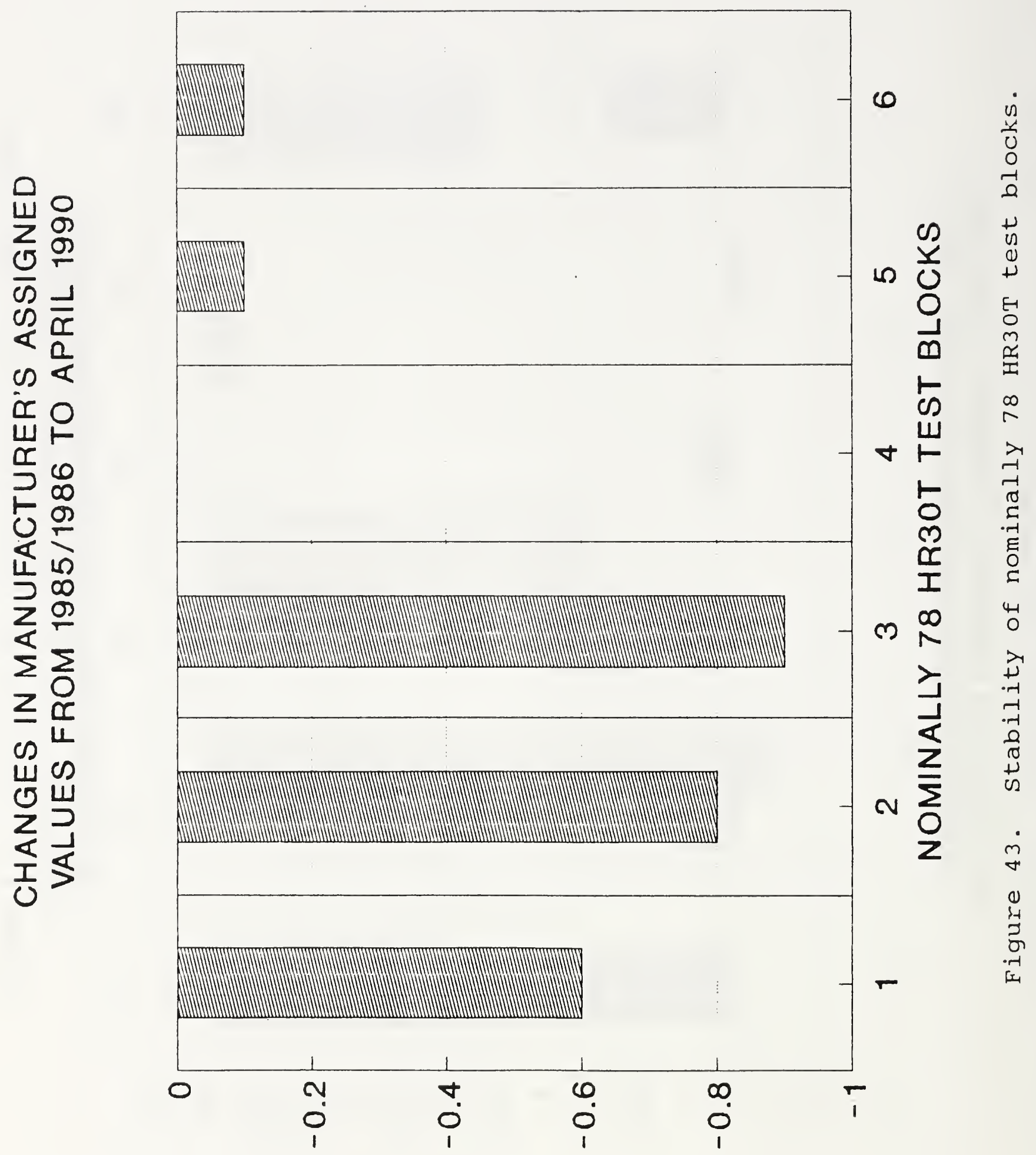

エロMOト गZートめ 
Intercomparison Study of Rockwell Hardness Test Blocks

\title{
AUTHOR(S)
}

I. Robert Shives and John H. Smith

\author{
PERFORMING ORGANIZATION (IF JOINT OR OTHER THAN NIST, SEE INSTRUCTIONS) \\ U.S. DEPARTMENT OF COMMERCE \\ NATIONAL INSTITUTE OF STANDARDS AND TECHMOLOGY \\ GAITHERSBURG, MD 20899
}

7. CONTRACT/GRANT NUMBER
8. TYPE OF REPORT AND PERIOD COVERED

SPONSORINO ORGANIZATION HAME AND COMPLETE ADDRESS (STREET, CITY, STATE, ZIP)

1. ABSTRACT 200-NORD OR LESS FACTUAL SUMMARY OF MOST SIGNIFICANT INFORMATION. IF DOCUMENT INCLUDES SIGNIFICANT BIBUOGRAPHY OR UTERATURE SURVEY, MENTION IT HERE.)

The Vational Institute of Standards and Technology undertook an intercomparison study of kockwell hardness test blocks marketed in the United States. This study was done at the request of $\therefore$ ST: Subcommittee 223.06 on Hardness. Test blocks from sir different manuEacturers were included in the study. Yeasurements were made generally on seven sets of test jlocks

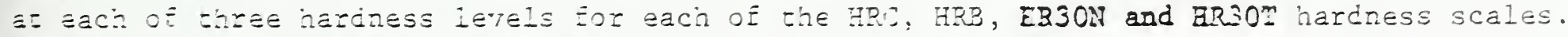
Ezrep: Zor a smail number o J zRC leasurements, testing was done using commercial hardiness EEsting macinines consigned to MISI for the study.

Eren Eor zhe nearly ideal conditions of the study, it ras found that there are siznizicant ¿izzerences among hardness zest blocks oj different manufactureres zor some hardness levele. This is especialiy true Eor the hizh hariness part of the HRC scale, the lower and midile

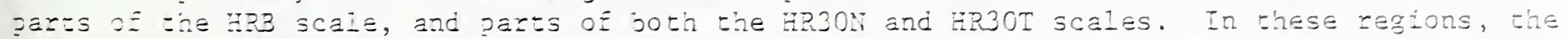
ranzes zest resules zor jlocks of difierent manutacturers that have similar assigned values

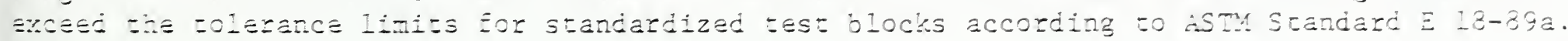

Ihe neasurement resuits to dot satiszy the ASTA E Iz-z9a uniformity requirements in a number o cases. This contrasts nith manufacturers' results mich do satisiy the Astal requiremerts.

Re€rEluation oE zated ziat nany oz zhese jiocks are instable. There were significant changes in hardness

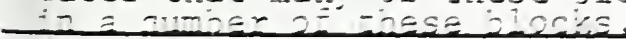

12. KEI HORDS (5 TO 12 ENTRIES; ALPHABETICAL ORDER; CAPITALZE ONLY PROPER NAMES; AND SEPARATE KEY WORDS BY SEMICOLONS)

heriness intercomparison; hariness; hariness test blocks; hardness test bIocks instabiliz; hardnes $=$ est block uniEormity; Rocknell hardness

FOR OFFICIAL DISTRIBUTION. DO HOT RELEASE TO NATIONAL TECHNICAL INFORMATION SERVICE (NTIS).

ORDER FROM SUPERINTENDENT OF DOCUMENTS, U.S. GOVERMMENT PRINTING OFFICE, NASHINGTON, OC 20402.

ORDER FROM HATIONAL TECHHICAL INFORMATION SERVICE (NTIS), SPRINGFIELD, VA 20151. 

